Marcelo Montaño

\title{
A APLICAÇÃO CONJUNTA DE MÉTODO DE PROJEÇÃO DAS ALTERAÇÕES NO USO E OCUPAÇÃO DO SOLO E DE INSTRUMENTOS DE POLÍTICA AMBIENTAL: O CASO DE SÃO CARLOS (SP)
}

\footnotetext{
Tese apresentada à Escola de Engenharia de São Carlos, da Universidade de São Paulo, como parte dos requisitos para a obtenção do título de Doutor em Engenharia (Hidráulica e Saneamento).
}

Orientador: Prof. Titular Marcelo Pereira de Souza

São Carlos

2005 


\section{AGRADECIMENTOS}

Ao Professor Marcelo Pereira de Souza, pela orientação e confiança ao longo de mais uma jornada, e sobretudo pelo grande respeito e amizade demonstrados nos momentos críticos.

Ao Conselho Nacional de Desenvolvimento Científico e Tecnológico - CNPq, pela concessão de bolsa de pesquisa.

Aos integrantes da Comissão Julgadora, indistintamente, pela compreensão e pelas valiosas contribuições para o trabalho.

Aos professores e funcionários do Departamento de Hidráulica e Saneamento da Escola de Engenharia de São Carlos, em especial aos professores Eduardo Cleto Pires e Maria do Carmo Calijuri, à Pavi, Sá, Rose e Bruno.

Aos amigos Victor, Aurélio, Aldo (Pêxe), Marcelo (Yoda) e Isabel, pela convivência pessoal e profissional. Aos novos amigos do LabSIG Elisânia, Rodrigo, Denis, Tatiana e Clara.

Agradecimentos especiais ao meu grande revisor e companheiro de jornada, sobretudo nas ondas virtuais, André Pereira de Souza (Deda).

Aos amigos atualmente espalhados pelo mundo.

A meus pais Raul e Neide, pelo apoio incondicional e compreensão fora do comum.

À minha família Claudine, Francisco e, agora, ao mais novo anjo que se aproxima (que seja muito feliz, Antônio). À casa nova....

Agradecimentos especiais à minha querida Claudine, pela superação, pelo carinho e paciência demonstrados a cada novo degrau superado. 


\section{RESUMO}

MONTAÑO, M. (2005). A aplicação conjunta de método de projeção das alterações no uso e ocupação do solo e de instrumentos de política ambiental: o caso de São Carlos (SP). 102 p. Tese (Doutorado) - Escola de Engenharia de São Carlos, Universidade de São Paulo, São Carlos, 2005.

A integração do ferramental técnico-científico disponível com os diferentes instrumentos de política e gestão ambiental é essencial para a compatibilização das exigências impostas pelo desenvolvimento com a manutenção ou melhoria da qualidade ambiental e social e, também, para o equacionamento das demandas e dos interesses de cada setor envolvido no processo decisório. Assim, os modelos para a projeção das alterações no uso e ocupação do solo de um determinado território têm sido freqüentemente utilizados. A modelagem propicia a geração e a avaliação das informações para montagem de um panorama das possíveis alterações no uso do solo, considerando que as tendências identificadas para aquele território, num certo instante, sejam mantidas de modo a se desenvolverem de acordo com um determinado cenário projetado. O presente trabalho analisa a possibilidade de aplicação conjunta do método de projeção das alterações no uso e ocupação do solo e instrumentos de política ambiental, levando em conta os aspectos preventivos. Aplicado a uma porção do município de São Carlos (SP), o trabalho apresenta uma projeção para a expansão urbana para os anos de 2012 e 2019, considerando três cenários alternativos de ocupação territorial. Confrontando os resultados obtidos pela modelagem com a capacidade de suporte do meio para a implantação de empreendimentos urbanos - determinada a partir da elaboração de um zoneamento ambiental, verifica-se que, mantidas as tendências atuais, e para os três cenários de ocupação avaliados, a expansão urbana continuará avançando sobre áreas de baixa aptidão para a urbanização, permanecerá exercendo intensa pressão sobre os recursos hídricos e os fragmentos de vegetação nativa, caso não sejam adotadas medidas que modifiquem o atual padrão de ocupação do território.

Palavras-chave: gestão ambiental; instrumentos de política ambiental; modelo de projeção de uso e ocupação do solo, expansão urbana. 


\begin{abstract}
MONTAÑO, M. (2005). The joint application of projection methods of the alteration on land use and the environmental policy tools: the São Carlos (SP) case. 102 p. Thesis (Doctoral) - Escola de Engenharia de São Carlos, Universidade de São Paulo, São Carlos, 2005.
\end{abstract}

To compatibilize the demands raised by development with the maintenance or improvement of the social and environmental quality, the integration among technical scientific tools and environmental management instruments is essential to solve the interests of each sector involved at the decision process. On this context are inserted land use and cover change models. The modelling permit the decision-making process to be done evaluating the consequences of possible alterations on land use, which can be identified considering the scenarios projected for the territory under certain circumstances. The present work analyses the possibility of joint application of this technique and environmental policy tools considering preventive aspects. Allocated to a portion of the São Carlos (SP) municipality, the work predicts urban growth for the years 2012 and 2019, considering three alternative scenarios of occupation. Confronting the results obtained by the model with the carrying capacity for the implementation of urban activities - determined from the elaboration of Environmental Zoning, is showed that, maintained the present tendencies, and for the scenarios evaluated, the urban growth will continue forward and towards the areas with low suitability. In the same way, the pressure over water resources and fragments of native vegetation will remains intense unless measures to modify the standards in occupation can be adopted.

Key-words: environmental management, environmental policy tools, urban growth, land use and cover change models. 


\section{LISTA DE FIGURAS}

Figura 1. Sustentabilidade ambiental, a partir das considerações de Souza (2000)

Figura 2. Recorte adotado para o presente trabalho, em relação ao município de São Carlos e detalhamento sobre o recorte

Figura 3. Localização do município de São Carlos, em relação ao Estado de São Paulo, e à Região Administrativa Central

Figura 4. Esquema simplificado para a realização da modelagem e do zoneamento ambiental

Figura 5. Área urbana em 1998 e 2005

Figura 6. Procedimento de calibração

Figura 7. Procedimentos para a validação do modelo

Figura 8. Exemplo de ponderação de fatores ambientais para elaboração de zoneamento ambiental

Figura 9. Número de células correspondentes à expansão urbana no período 1998-2005 por: (A) tipos de solo; (B) declividade; (C) altitude; (D) distância a rodovias existentes em 1998.

Figura 10. Número de células correspondentes à expansão urbana no período 1998-2005 por: (E) distância a vias de acesso e ligação existentes em 1998; (F) distância a "empreendimentos indutores de crescimento", e (G) distância à área urbana em 1998

Figura 11. Mapas de probabilidade de transição NÃO-URBANO/URBANO, para as combinações de melhor desempenho na regressão logística

Figura 12. Área urbana prevista pelo modelo GEOMOD para o ano de 2005 a partir do mapa de probabilidades de transição gerado para as combinações $A+B+D+E$ (esq.) e $A+B+E+G$ (centro). Área urbana real para o ano 2005

Figura 13. Mapa de uso e ocupação do solo para o ano de 1998 a partir de imagem classificada, e mapa reclassificado para apenas três categorias (USO AGRÍCOLA/RURAL, VEGETAÇÃO NATIVA e URBANO)

Figura 14. Mapa de uso e ocupação do solo para o ano de 2005 a partir de imagem classificada, e mapa reclassificado para apenas três categorias (USO AGRÍCOLA/RURAL, VEGETAÇÃO NATIVA e URBANO)

Figura 15. Mapas de uso e ocupação do solo para os anos 2012 e 2019, para as categorias NÃO-URBANA e URBANA, conforme Cenário I 
Figura 16. Mapas de uso e ocupação do solo para os anos 2012 e 2019, para as categorias NÃO-URBANA e URBANA, conforme Cenário II

Figura 17. Mapas de uso e ocupação do solo para os anos 2012 e 2019, para as categorias NÃO-URBANA e URBANA, conforme Cenário III

Figura 18. Mapa de classes de capacidade de uso do solo para a área de estudo, e respectivo mapa reclassificado conforme sua aptidão para ocupação urbana

Figura 19. Mapa de vulnerabilidade dos recursos hídricos subterrâneos gerado para a área de estudo, e respectivo mapa reclassificado conforme sua aptidão para ocupação urbana

Figura 20. Detalhe sobre a malha urbana atual

Figura 21. Aptidão para ocupação urbana segundo os temas avaliados. "Aptidão do Terreno", "Aptidão Geologia" e "Aptidão Mananciais"

Figura 22. Combinação dos temas avaliados, segundo ponderação descrita (zoneamento ambiental para ocupação urbana)

Figura 23. Localização das bacias hidrográficas dos córregos do Gregório, Santa Maria do Leme, e das bacias de captação do Monjolinho/Espraiado e do Feijão, em relação à malha urbana atual 


\section{LISTA DE TABELAS}

Tabela 1 - Critérios para a determinação da Capacidade de Uso do Solo, segundo Montaño, Bertolani e Souza (2004)

Tabela 2 - Classes de aptidão para a ocupação urbana adotadas em função da Capacidade de Uso do Solo

Tabela 3 - Classes de vulnerabilidade adotadas em função de intervalos de declividade

Tabela 4 - Classes de vulnerabilidade adotadas em função da profundidade do solo

Tabela 5 - Classes de vulnerabilidade adotadas em função da permeabilidade do solo

Tabela 6 - Classes de aptidão para a ocupação urbana em função da vulnerabilidade dos recursos hídricos subterrâneos

Tabela 7 - Ponderação efetuada para a obtenção do mapa "Aptidão do Terreno"

Tabela 8 - Ponderação efetuada para a obtenção do mapa "Aptidão Geologia" _

Tabela 9 - Ponderação efetuada para a obtenção do mapa "Aptidão Mananciais"

Tabela 10 - Ponderação efetuada para a obtenção do mapa "Aptidão para ocupação urbana"

Tabela 11 - Indicadores de desempenho para a regressão logística, em função da combinação entre as variáveis empregadas na regressão, e indicação das combinações de melhor desempenho

Tabela 12 - Índice de Concordância de Kappa para os mapas previstos para o ano de 2005, em comparação com o mapa real

Tabela 13 - Alterações no uso e ocupação do solo no período 1998-2005, para as categorias AGRÍCOLA, VEGETAÇÃO NATIVA e URBANA (em hectares)

Tabela 14 - Uso e ocupação do solo para os anos 2012 e 2019 (em hectares), para as categorias AGRÍCOLA, VEGETAÇÃO NATIVA e URBANA, projetado pelo método da Cadeia de Markov

Tabela 15 - Evolução da área urbanizada em função das classes de aptidão indicadas no zoneamento ambiental, de acordo com os cenários elaborados

Tabela 16 - Evolução da área urbanizada sobre as bacias hidrográficas, de acordo com os cenários elaborados 
Tabela 17 - Quantidade de vegetação nativa (em hectares) que sofreria interferência da urbanização, de acordo com os cenários projetados 


\section{LISTA DE SIGLAS}

CONAMA - Conselho Nacional do Meio Ambiente

CONSEMA - Conselho Estadual de Meio Ambiente

CPCB - Central Pollution Control Board (Índia)

CSR/UFMG - Centro de Sensoriamento Remoto da Universidade Federal de Minas Gerais

DEPRN - Departamento Estadual de Proteção aos Recursos Naturais

EESC - Escola de Engenharia de São Carlos

EIA - Estudo de Impacto Ambiental

EMBRAPA - Empresa Brasileira de Pesquisa Agropecuária

EPA - Environmental Protection Agency (EUA)

GEOMA - Rede Temática de Pesquisa em Modelagem Ambiental da Amazônia ICSU - International Council for Science

IHDP - International Human Dimensions Programme on Global Environmental Change

INPE - Instituto Nacional de Pesquisas Espaciais

LUCC - Land Use and Cover Change

MCE - Multi-criteria evaluation

MCT - Ministério da Ciência e Tecnologia

NIMBY - Not In My BackYard

ROC - Relative Operating Characteristic

SEADE - Fundação Sistema Estadual de Análise de Dados (São Paulo)

UFSCar - Universidade Federal de São Carlos

USDA - United States Department of Agriculture (EUA)

USP - Universidade de São Paulo

ZEE - Zoneamento Ecológico Econômico 


\section{SUMÁRIO}

1. INTRODUÇÃO

2. OBJETIVOS

2.1. Objetivo geral

2.2. Objetivos específicos

3. REVISÃO BIBLIOGRÁFICA

3.1. Interfaces entre instrumentos de gestão e Política ambiental e o ordenamento do uso do solo

3.2. Participação da sociedade no processo decisório ambiental

3.3. 0 zoneamento ambiental - aplicações e desdobramentos para a gestão municipal

3.4. Modelagem para avaliação da alteração do uso e cobertura do solo fundamentos e aplicações na gestão ambiental

3.4.1. Aplicações

4.1. Delimitação e caracterização da área de estudo

4.2. Materiais

4.3. Descrição da metodologia

4.3.1. Descrição dos procedimentos de modelagem e projeção da expansão urbana

4.3.1.1. Calibração

4.3.1.2. Validação

4.3.1.3. Previsão

4.3.2. Descrição da metodologia empregada na elaboração do zoneamento ambiental

4.3.2.1. Avaliação da capacidade de carga do terreno

4.3.2.2. Vulnerabilidade dos recursos hídricos subterrâneos

4.3.2.3. Ponderação sobre os fatores

\section{RESULTADOS E DISCUSSÃO}

5.1. Modelagem e projeção da expansão urbana

5.1.1. Calibração

5.1.1.1. Verificação do relacionamento das variáveis independentes com o fenômeno 
5.1.1.2. Desempenho das combinações entre as variáveis independentes para a geração do mapa de probabilidades de transição

5.1.2. Validação

5.1.3. Previsão

5.1.3.1. Projeção futura da quantidade de células para o estado 2

5.1.3.2. Geração de cenários

5.2. Descrição da metodologia empregada na elaboração do zoneamento ambiental

5.2.1. Avaliação da capacidade de carga do terreno

5.2.2. Vulnerabilidade dos recursos hídricos subterrâneos

5.2.3. Ponderação sobre os fatores

5.3. Aplicação conjunta com outros instrumentos de gestão ambiental

5.3.1. Aplicações com o zoneamento ambiental

5.3.2. Aplicações em Avaliação de Impactos Ambientais

5.3.3. Aplicações no processo de licenciamento de atividades

5.4. Discussão geral 


\section{INTRODUÇÃO}

Dentre as necessidades específicas dos agentes envolvidos com a gestão ambiental de um determinado território, quais sejam: os administradores públicos e privados, os planejadores e a sociedade em geral, a existência de informações que permitam equacionar as demandas e os interesses de cada setor envolvido no processo decisório é fundamental, na perspectiva de compatibilizar as exigências do desenvolvimento (econômico, social) com a manutenção ou melhoria da qualidade ambiental e de vida.

Para que se consiga tal compatibilização, sob a lógica do Desenvolvimento Sustentável, surge a necessidade de se observar determinados preceitos relacionados à sustentabilidade ambiental, incorporados especialmente ao modelo de desenvolvimento adotado pela sociedade. Segundo tais preceitos, as decisões relativas às atividades humanas deveriam considerar, necessariamente, as dimensões espacial (avaliando-se as características do meio em que se pretende inserir a atividade em questão) e temporal (ampliando o horizonte de avaliação tanto quanto for possível, de modo a verificar as conseqüências para as gerações futuras), 
e garantir a participação da sociedade no processo decisório (garantindo com isso o atendimento às necessidades das presentes gerações).

Um passo importante nesse sentido, além do direcionamento adequado das discussões relativas às conseqüências do modelo de desenvolvimento adotado, refere-se à disponibilização de ferramentas que permitam aos tomadores de decisão integrar e avaliar, de forma consistente, as informações disponíveis relacionadas às alterações nos padrões de ocupação de um determinado território. As atuais modificações no uso e ocupação do solo constituem uma fonte de preocupação para cientistas e pesquisadores de todo o globo, uma vez que estão associadas a uma ampla gama de impactos de natureza negativa.

$\mathrm{Na}$ geração e avaliação de mapas obtidos a partir da modelagem das alterações de uso e ocupação do solo, tem-se em mãos um panorama das possíveis alterações no uso do solo caso as tendências identificadas para aquele território, num certo instante, sejam mantidas de modo a se desenvolverem de acordo com um cenário projetado.

A partir das informações geradas, é possível visualizar e avaliar as conseqüências e implicações de decisões políticas e de ações que venham modificar os padrões de ocupação do território. Atualmente, a comunidade científica empreende um grande esforço para o desenvolvimento de modelos que contemplem as necessidades de planejadores e sociedade, que possam ser utilizados como ferramenta de apoio à tomada de decisão. Exemplos de aplicação e estudos realizados na área são apresentados, dentre outros, por Clarke e Gaides (1998), Schneider e Pontius Jr. (2001), Hathout (2002), Silva e Clarke (2002), Pedrosa (2003), Aspinall (2004) e Pontius Jr e Malanson (2005). 
O presente trabalho pretende apresentar e discutir sobre os principais pontos que envolvem a modelagem das alterações de uso e ocupação do solo, e avaliar as possibilidades de sua aplicação na gestão ambiental do território. Para tanto, além de uma reflexão sobre o atual estágio de desenvolvimento dos modelos em aplicação, é discutida a contribuição da modelagem na dinâmica de aplicação de alguns instrumentos de gestão definidos na política ambiental brasileira.

Aplicado a uma porção do território do município de São Carlos (SP), o trabalho procura associar o modelo GEOMOD - aplicado para a projeção da expansão urbana de acordo com diferentes cenários de desenvolvimento - a alguns instrumentos de gestão ambiental, com destaque ao zoneamento ambiental e avaliação de impacto ambiental, conforme apresentado por Canter (1996), Souza (2000), Glasson et al. (2001), levando-se em conta também algumas considerações encontradas em Guerra e Cunha (2001), Jacobi (2000) e Mota (1999) para o ambiente urbano.

Permeando todo referencial conceitual adotado no presente trabalho, o destaque à participação da sociedade (entendida como um elemento essencial para a adequação e validação do processo decisório) é realizado com a intenção de contextualizar as discussões efetuadas a partir do estudo de caso apresentado, no âmbito específico da gestão ambiental do espaço público. 


\section{OBJETIVOS}

\subsection{Objetivo geral}

Analisar a aplicabilidade conjunta do método de projeção das alterações no uso e ocupação do solo e instrumentos de política ambiental, considerando-se aspectos preventivos.

\subsection{Objetivos específicos}

$\checkmark$ Aplicação do modelo GEOMOD para a modelagem da expansão urbana para a área de estudo (localizada no município de São Carlos - SP) a partir das tendências identificadas no período 1998-2005;

$\checkmark$ Projeção para os anos de 2012 e 2019 considerando-se cenários alternativos de expansão territorial;

$\checkmark$ Elaboração do zoneamento ambiental para expansão urbana, para a área de estudo; 
$\checkmark$ Aplicação dos resultados obtidos pela modelagem junto aos instrumentos zoneamento ambiental, avaliação de impactos ambientais e licenciamento de atividades. 


\section{REVISÃO BIBLIOGRÁFICA}

O presente capítulo apresenta uma revisão bibliográfica dos principais temas contemplados no trabalho. O intuito é mostrar, em cada uma das áreas do conhecimento, como diversos pesquisadores e centros de pesquisa têm abordado os respectivos temas, para em seguida apresentar o modelo escolhido, os resultados e compará-los frente às considerações aqui apresentadas.

Para tanto, o presente capítulo aborda: as interfaces entre instrumentos de gestão e de Política ambiental e o uso do solo; a participação da sociedade como importante elemento de implementação de Política ambiental com um cunho mais democrático; o zoneamento ambiental e suas aplicações como instrumento de gestão ambiental e, por fim, as aplicações de modelagem para o uso e ocupação do solo.

\subsection{Interfaces entre instrumentos de gestão e Política ambiental e o ordenamento do uso do solo}

Atualmente, os instrumentos de gestão ambiental têm sido questionados, em grande medida, pelo setor produtivo (sobretudo os setores agrícola, industrial e energético), sob a alegação de causar um "emperramento" das atividades 
econômicas e atrasar o seu cronograma de implantação, gerando prejuízos e desestímulo ao setor produtivo. Como conseqüência verifica-se a inclusão, na agenda política do governo, da opção de desregulamentação destes instrumentos, sem levar em conta a grande desorientação técnica que se observa, muitas vezes, em sua aplicação.

É possível notar, por exemplo, que o licenciamento ambiental de atividades públicas ou privadas passa por um momento de grande polêmica entre o setor produtivo, a sociedade civil organizada e os órgãos governamentais responsáveis pela análise dos projetos e emissão de licenças. As discussões têm trazido à tona a necessidade de uma reflexão sobre o papel dos instrumentos e da própria Política Nacional de Meio Ambiente (SOUZA, ABDON e OLIVEIRA, 2005).

Reforçando estas colocações, diversos autores consideram que, mesmo diante de dificuldades e deficiências de implantação, estes instrumentos desempenham um papel estratégico e com perspectivas reais de contribuir com princípios e critérios para que se alcance a sustentabilidade ambiental (SÁNCHEZ, 1993; LIMA et al., 1995; BRITO, 1996). Caso sejam empregados adequadamente, esperam-se melhores decisões e melhores projetos contemplando as questões ambientais (THERIVEL et al., 1994; GLASSON et al., 2001).

Ao considerarem que a opção pela inserção gradativa de valores ambientais no processo decisório político e econômico, preconizada desde a Conferência das Nações Unidas para o Desenvolvimento Sustentável, em 1992, ainda não conseguiu modificar significativamente o processo produtivo, Oliveira e Souza (2005) destacam a necessidade de se atentar para que os valores econômicos não continuem se sobrepondo ao conjunto de valores ambientais, distanciando a sociedade cada vez mais do paradigma de sustentabilidade ambiental. 
Conforme as considerações de Souza (2000), a sustentabilidade ambiental (em termos sociais, econômicos e ambientais) só poderá ser almejada quando as decisões que envolvem a utilização de recursos ambientais forem tomadas com base nos seguinte elementos: a dimensão temporal - observando as necessidades das presentes e futuras gerações; a dimensão espacial - que observa as especificidades do meio; e a participação da sociedade nos processos decisórios, como medida de legitimação, por meio da prática do debate democrático.

Neste contexto, a figura 1 ilustra a sustentabilidade ambiental como a interação entre desenvolvimento econômico, desenvolvimento (ou eqüidade) social e equilíbrio ambiental tendo como referência a capacidade de suporte do meio - um conceito que atualmente é empregado por diferentes ciências ${ }^{1}$, o que tem provocado uma certa distorção em seu entendimento.

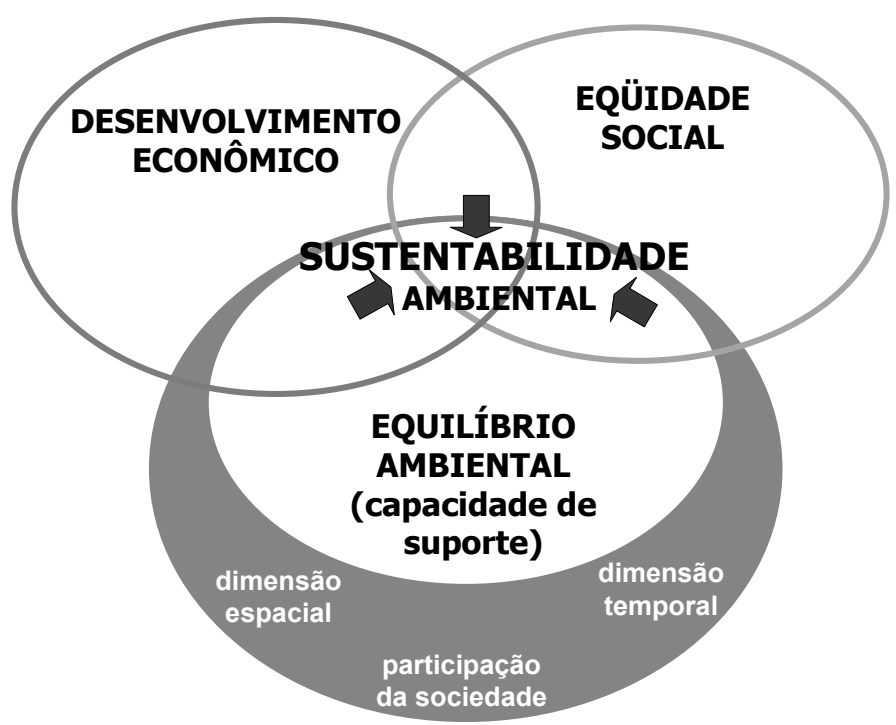

Figura 1. Sustentabilidade ambiental, a partir das considerações de Souza (2000).

\footnotetext{
${ }^{1}$ No presente trabalho, o conceito de capacidade de suporte segue a definição dada por Filet (1995), como a habilidade do ambiente em acomodar, assimilar e incorporar um conjunto de atividades antrópicas sem inviabilizar suas funções naturais em termos de produtividade primária e, ainda, proporcionar padrões de vida aceitáveis às populações que habitam esses ambientes.
} 
Segundo Vitousek (1994) ${ }^{2}$ apud Agarwal et al. (2002), as atuais modificações no uso e ocupação do solo constituem a mais evidente e perceptível das alterações em escala global que se encontram devidamente documentadas e comprovadas (além desta, o autor menciona ainda a concentração crescente de dióxido de carbono na atmosfera e as modificações na bioquímica do ciclo global do nitrogênio, ambas tão preocupantes e relacionadas à primeira).

As alterações no uso do solo têm impacto direto na biodiversidade mundial (MITTERMEIER et al, 2000), contribuem para alterações no clima local e global (SOLECKI e OLIVERI, 2004), modificam as propriedades químicas do solo como concentração de carbono e nutrientes (HOWARD et al., 1995; PRIESS et al., 2001), dentre outras implicações nos sistemas ambientais. Tais alterações ainda determinam, em parte, a vulnerabilidade de locais e indivíduos a perturbações de ordem climática, econômica ou sócio-política (KASPERSON et al., $1995^{3}$ apud LAMBIN et al., 2001).

Dentre estas alterações, o processo de ocupação do território para fins urbanos se destaca por uma série de modificações relacionadas à qualidade do meio: poluição e contaminação dos recursos hídricos superficiais e subterrâneos por fontes pontuais ou difusas, poluição do ar, alteração das características das águas de chuva, erosão e contaminação do solo, supressão da vegetação, deslocamento da fauna, modificações das condições sócio-econômicas, impactos diversos nas populações locais, alterações nos micro e meso climas, etc... (CANTER, 1996; CHARACKLIS e WIESNER, 1997; ZANDBERGEN, 1998; SUTHERLAND e

\footnotetext{
${ }^{2}$ VITOUSEK, P. M. (1994). Beyond global warming: ecology and global change. Ecology 75:1861-1876.

${ }^{3}$ KASPERSON, J.X., KASPERSON, R.E., TURNER, B.L. II (Eds.) (1995). Regions at Risk: Comparisons of Threatened Environments. United Nations Univ. Press, Tokyo.
} 
TOLOSA, 2000; TUCCI, 2000; BRANDÂO, 2001; FREITAS et al., 2001; LURIA e ASPINALL, 2003; ZANNIN et al, 2003; SULLIVAN et al, 2004; TUCCI, 2005).

Os problemas decorrentes da urbanização do território são gerados pela combinação de diferentes fatores. Definitivamente, as características do meio físico são determinantes para o sucesso ou para o fracasso das intervenções urbanas. Contudo, como observa Tucci (2001), o aspecto central da questão ainda envolve uma cultura desatualizada e equivocada dos profissionais (técnicos ou administradores) que atuam no meio urbano, que impõe a adoção de soluções puramente estruturais, muitas vezes menos eficientes do ponto de vista técnico e econômico, e potencialmente desastrosas para o meio ambiente. Para o autor, uma vez que o planejamento da ocupação do espaço urbano no Brasil não tem considerado aspectos fundamentais, tal ocupação acaba por gerar grandes transtornos e uma série de custos para a sociedade e para o ambiente como um todo.

Cabe destacar que, dentro de um panorama histórico, a ênfase dada ao desenvolvimento econômico a qualquer custo, a partir dos anos 1960, impõe aos planejadores do uso do solo uma grande pressão pela manipulação dos espaços privados (MOREIRA, 1993). Associada a este fator, a constante conversão de uso da terra e de reestruturação fundiária que ocorre nas áreas rurais contíguas à zona urbana, e que são afetadas diretamente pela expansão urbana, faz com que ocorra uma sobreposição de atividades entre os territórios urbanos e rurais bastante característica dessa zona de transição (SULLIVAN, ANDERSON e LOVELL, 2004).

Conforme Bottari (2005), o processo de urbanização das cidades brasileiras tem se desenvolvido e caracterizado predominantemente por meio do parcelamento do solo na abertura de franjas de expansão de loteamentos e desmembramentos de 
gleba. Para Ab'Saber (2004, comunicação pessoal) um outro fator preocupante é o que se chama de "urbanização por saltos", em que áreas de características rurais desconectadas da malha urbana são urbanizadas segundo a ótica dos empreendedores, gerando um custo ao poder público para a incorporação destas áreas ao sistema urbano, sobretudo quanto à provisão de infra-estrutura de saneamento, transporte e serviços públicos.

Tal processo vem se desenvolvendo de maneira dissociada de um planejamento integrado, e sem a incorporação da dimensão temporal nas ações que guiam a ocupação do espaço, determinada em grande medida pela ação especulativa. Os resultados deste planejamento unilateral (no sentido de considerar apenas necessidades econômicas de curto prazo, impostas à coletividade por grupos que defendem interesses específicos) são verificados de diferentes modos e, conforme Stren (1992), se colocam na contramão em relação aos conceitos de sustentabilidade que se preconizam como paradigma (segundo os quais a descentralização e democratização do processo decisório são essenciais), inclusive com um grande comprometimento social.

Bottari (2005) comenta que a inserção da questão ambiental no processo de planejamento da ocupação do espaço urbano tem sido defendida já há algum tempo, porém sem que isso tenha significado, na prática, a sua incorporação efetiva ao processo decisório, ficando mais restrita a atividades ligadas ao setor de saneamento. Uma das razões para essa situação pode ser atribuída à desarticulação entre os instrumentos de política e gestão ambiental e os instrumentos empregados no ordenamento do uso do solo urbano.

A Lei 10.257 de 2001 (conhecida como o Estatuto da Cidade), que estabelece diretrizes gerais de política urbana, constitui a base legal e institucional que passou 
a orientar o planejamento dos municípios a partir de sua promulgação, notadamente no que diz respeito à elaboração de seus planos diretores (que são, conforme o artigo 182 da Constituição Federal, parágrafo $1^{\circ}$, o "instrumento básico da política de desenvolvimento e de expansão urbana"). Ao estabelecer que os municípios devem considerar todo o seu território como unidade de planejamento, verifica-se a necessidade de incluir os aspectos ambientais no que diz respeito ao ordenamento do uso e ocupação do território municipal.

O Estatuto faz, ainda, referência a novos instrumentos e novas aplicações para instrumentos já existentes tanto para a área ambiental quanto para o planejamento urbano, sem que isso tenha significado a obrigatoriedade de incorporação dos instrumentos de gestão e planejamento ambiental ao processo de gestão territorial do município.

Um bom exemplo nesse sentido ocorre com o zoneamento ambiental, citado como um instrumento auxiliar ao plano diretor, mas cuja vinculação à sua elaboração não fica explícita. Além de se apresentar como um importante instrumento prévio e essencial ao plano diretor, o zoneamento ambiental (tratado com mais detalhes adiante) pode atuar como instrumento de referência para atividades pontuais (na avaliação da viabilidade ambiental de projetos) resgatando, nas especificidades de cada projeto ou empreendimento, o que não se conseguiu nas generalizações feitas quando da elaboração de um plano diretor.

Um outro destaque que se faz sobre o Estatuto da Cidade diz respeito à necessária participação da sociedade nos processos decisórios, reforçando e aprimorando uma prática já preconizada pela Política Nacional do Meio Ambiente, no âmbito da gestão municipal do território. 
A diversidade de situações e as respostas aos impactos e às prioridades relativas ao meio ambiente estão intimamente ligadas aos valores da sociedade, às especificidades físicas do meio ambiente e, conseqüentemente, às relações existentes entre a natureza e uma determinada sociedade.

Assim, de acordo com Frey (2000), a necessidade de transformações significativas dos arranjos institucionais ocorridos pelo incremento da "consciência ambiental" da sociedade, às vezes compulsória e imposta por ações unilaterais ou normas jurídicas, tem carecido de um significativo esforço político para a administração dos conflitos entre os interesses econômicos e as necessidades ambientais.

Tal esforço tem culminado, via de regra, na ampliação dos canais de comunicação entre governo e sociedade em diferentes momentos do processo de tomada de decisão.

\subsection{Participação da sociedade no processo decisório ambiental.}

A Conferência das Nações Unidas para o Ambiente e Desenvolvimento em 1992 trouxe alguns pontos marcantes para o estabelecimento de novos mecanismos de relacionamento entre governo e sociedade, dentre os quais, o papel da participação da sociedade como agente do processo de desenvolvimento e que, portanto, deve partilhar do processo decisório com as autoridades e entidades responsáveis.

Tal participação pode ser entendida como um processo que se concretiza por meio do diálogo, do esclarecimento antecipado e da incorporação de contribuições e valores expressos pela sociedade na decisão final. $O$ envolvimento da sociedade 
deveria se iniciar, de modo ideal, previamente à concepção de qualquer projeto em pauta, para que suas demandas fossem contempladas adequadamente no âmbito de definição política e de tomada de decisões.

Tress e Tress (2003) entendem que a participação da sociedade no processo decisório, desde o início do processo de planejamento, tem como conseqüência um maior comprometimento dos diferentes setores envolvidos (governo e sociedade), conduz a um nível mais elevado de satisfação do cidadão ("usuário", em última instância, da proposta avaliada), cria expectativas mais realistas a respeito dos desdobramentos futuros, e aumenta o nível de confiança no processo como um todo.

Para Selman (2000), o envolvimento do público na tomada de decisões é uma maneira prática de validação social das propostas formuladas. Contudo, cumpre destacar que a participação pode se tornar um instrumento para a manipulação e a justificativa de decisões que não contemplem os anseios da sociedade, apoiada em um cenário teatral que a investe de credibilidade pela existência da platéia. Dessa forma, na opinião de Santos (2004), projetos de interesse privado que não seriam prioritários para a sociedade, podem encontrar o caminho aberto para a sua legitimação.

O grande desafio que se coloca para a gestão ambiental está em encontrar formas adequadas de exploração das potencialidades do processo participativo, em que a sociedade seja definitivamente chamada à sua responsabilidade de zelar pelo meio ambiente e que, ao mesmo tempo, tenha oportunidade para contribuir com o processo decisório de modo efetivo (MONTAÑO, OLIVEIRA e SOUZA, 2005).

Tal afirmação está relacionada ao espaço ocupado, numa sociedade, pela prática do debate entre os diferentes atores que a compõem. Como observa Leis 
(2001), não existe possibilidade de negociação sem haver espaços aptos para uma participação baseada num debate eficiente, em que os melhores argumentos tenham uma chance real de prevalecer frente às visões instrumentais dos atores políticos e econômicos tradicionais.

Imaginando a existência de tais espaços, e de tais debates, o nível de argumentação a ser estabelecido deverá ser diretamente relacionado ao grau de esclarecimento e maturidade demonstrado pelos diferentes segmentos da sociedade com relação a esta ou àquela questão.

Sobre esse aspecto, Serres (1990) observa que dois interlocutores, mesmo que obstinados em contradizerem um ao outro, e ainda que aceitem prosseguir com uma discussão infindável, precisam falar uma linguagem comum para que o diálogo se estabeleça. Não há comunicação e, por conseguinte, nem contradição entre duas partes, caso não exista uma linguagem comum a elas. Nesse sentido, de acordo com Alton e Underwood (2003), os termos técnicos cumprem muitas vezes o papel de afastar aqueles que não os compreendem, a fim de limitar sua capacidade de entendimento e de argumentação.

Sendo assim, não é coerente esperar que um indivíduo ou uma organização possa contribuir de maneira efetiva e eficaz sem que conheça a sistemática, os fundamentos e os objetivos da proposta de desenvolvimento sobre a qual se propõe a participar (PARTIDÁRIO, 1999).

Como decorrência da participação sem o devido esclarecimento sobre determinado evento e suas respectivas conseqüências, estabelece-se o conhecido efeito NIMBY (Not In My BackYard - "não no meu quintal"). Tal efeito traduz, segundo a autora, a ausência de um sentimento de co-responsabilização comum a todos os participantes do processo decisório, o que reflete a tendência de se 
salvaguardar os interesses de poucos indivíduos, em detrimento do interesse coletivo.

No Brasil, a institucionalização da participação da sociedade nos processos decisórios - de modo consultivo e deliberativo - que envolvem o meio ambiente remonta à própria Política Nacional do Meio Ambiente, instituída em 1981, com a criação do Conselho Nacional do Meio Ambiente (CONAMA), servindo de exemplo e incentivo para a criação dos respectivos Conselhos Estaduais e Municipais.

Conforme Machado (2002), em alguns órgãos colegiados, o CONAMA inclusive, a participação do público (desconsiderando-se os representantes dos setores usuários, que têm sua participação comprometida pelos interesses econômicos) é muitas vezes numericamente inferior à dos outros setores, o que não oferece muita oportunidade para influir no processo decisório. Nesse caso as associações passam a ter o papel mais voltado para a fiscalização do processo decisório do que de participantes da tomada de decisão.

Os Conselhos estaduais, em especifico o CONSEMA - Conselho Estadual do Meio Ambiente do Estado de São Paulo - padecem do mesmo mal. Segundo Mariano e Souza (1997), a centralização das decisões no âmbito dos Conselhos de Meio Ambiente se verifica, dentre outros aspectos, pela concentração das informações disponíveis.

Mesmo em situações nas quais o acesso à informação é assegurado por lei, não se garante a eficácia do processo de participação. Um dos mecanismos de participação social no processo decisório, expresso em lei, garante a realização de Audiências Públicas em certas etapas do licenciamento ambiental (Resolução CONAMA 09/1987). 
Sobre esse aspecto, Montaño, Oliveira e Souza (2005) alertam para o fato de se verificar nessas audiências, muitas vezes, que a sociedade organizada não dispõe das informações corretas e completas em tempo hábil para uma participação qualificada. Para as audiências públicas, a prestação da informação é um dos problemas a serem resolvidos.

Um ponto a ser destacado é que a participação da sociedade no estabelecimento dos critérios e das necessidades, na concepção dos cenários ambientais, é fundamental para que os instrumentos de planejamento e gestão ambiental possam contribuir, de maneira adequada, para a solução técnica a ser adotada e, ao contemplar a participação, atender as necessidades da sociedade. Assim, contribuem para a minimização dos potenciais conflitos decorrentes da tomada de decisão.

\subsection{O zoneamento ambiental - aplicações e desdobramentos para a gestão municipal}

Apesar do zoneamento ambiental ter sido criado há mais de duas décadas, inserido na Política Nacional de Meio Ambiente (Lei $\mathrm{n}^{\circ}$. 6.938/81, artigo 9², inciso II) como um instrumento de gestão ambiental, percebe-se que a sua implementação prática ainda não tem conseguido fazer valer toda a potencialidade deste que pode ser considerado o instrumento de gestão ambiental mais dinâmico dentre todos os instrumentos preconizados na referida Política

Na fronteira Amazônica, por exemplo, tem sido apresentado há algum tempo um instrumento para o zoneamento do território capaz de reverter alguns dos 
problemas de ocupação desordenada, que tanto despertam a atenção da opinião pública internacional desde os anos 80 (NITSCH, 1998; SAE, 2000).

No entanto, ao estabelecer uma determinada divisão do território em termos das atividades que podem ou não ser desenvolvidas, esse tipo de zoneamento acaba por desviar-se de sua verdadeira atribuição como instrumento de planejamento e gestão ambiental - meio, e não fim, para a tomada de decisão. Pode-se observar a aplicação desta concepção de zoneamento nos trabalhos mais recentes de Zoneamento Ecológico Econômico (ZEE), elaborados para os Estados do Acre (2000), Rondônia (2001), Maranhão (2002) e Mato Grosso (2003).

O governo federal tem se mostrado favorável à elaboração de uma base metodológica que consolide uma nova concepção de zoneamento, fundamentada na participação da sociedade através de ampla divulgação e discussão das informações levantadas.

Numa primeira tentativa de se desfazer alguns desentendimentos relacionados à aplicação deste instrumento, o Decreto 4.297, de 10 de julho de 2002, que regulamenta o art. $9^{\circ}$, II, da Lei 6.938/81, estabelece que "o ZEE, instrumento de organização do território a ser obrigatoriamente seguido na implantação de planos, obras e atividades públicas e privadas, estabelece medidas e padrões de proteção ambiental destinados a assegurar a qualidade ambiental, dos recursos hídricos e do solo e a conservação da biodiversidade, garantindo o desenvolvimento sustentável e a melhoria das condições de vida da população" (artigo $2^{\circ}$ ).

Ainda, em seu artigo $3^{\circ}$, estabelece que "o ZEE, na distribuição espacial das atividades econômicas, levará em conta a importância ecológica, as limitações e as fragilidades dos ecossistemas, estabelecendo vedações, restrições e alternativas de 
exploração do território e determinando, quando for o caso, inclusive a relocalização de atividades incompatíveis com suas diretrizes gerais".

Pouco se avançou no sentido de esclarecer qual deve ser o papel deste instrumento na gestão ambiental, seja no que diz respeito à sua integração com outros instrumentos de gestão (MONTAÑO et al., 2004; OLIVEIRA, 2004), seja quanto à sua aplicação efetiva em escalas mais detalhadas, como seria no caso do município.

Sendo possível ao município a atribuição de metas específicas de uso e ocupação do solo relacionadas à adequação das atividades implantadas em seu território, baseadas em critérios estabelecidos sobre uma sólida base conceitual e metodológica, o Poder Público municipal teria em mãos mecanismos extremamente valiosos para fazer valer as diretrizes estabelecidas por uma política ambiental comprometida com a preservação de seus recursos naturais e com a compatibilização do desenvolvimento econômico com a manutenção da qualidade ambiental.

Historicamente, os exercícios de zoneamento no nosso país têm se relacionado a duas tradições (MILLIKAN \& PRETTE, 2000). A primeira refere-se à regulação do uso do solo urbano através de instrumentos normativos e tendo a saúde humana como preocupação central. A segunda tradição vem a ser o zoneamento agrícola ou agroecológico, elaborado com base em estudos sobre solos, clima, relevo e outros atributos naturais de interesse para o planejamento espacial de atividades produtivas do setor agropecuário. Essas modalidades de zoneamento são elaboradas seguindo objetivos e metodologias próprias que não devem ser confundidas com aquelas necessárias para o processo de elaboração do zoneamento ambiental, por uma razão fundamental: o foco deste último deve ser a 
identificação de aptidões do território para múltiplas atividades, considerando, como ponto de partida, a capacidade de suporte do meio.

Ainda que existam no Brasil diferentes experiências relacionadas à elaboração de zoneamentos ambientais, provenientes de diversas instituições de ensino e pesquisa (INPE, EMBRAPA, IBGE, UFSCar, UNICAMP, UFRGS, e outras), no escopo do presente trabalho o termo zoneamento ambiental acompanha o entendimento preconizado há algum tempo, no âmbito da Escola de Engenharia de São Carlos, e aplicado em trabalhos como Fontes (1997), Souza (2000), Ranieri (2000), Ranieri, Fontes e Souza (2002), Montaño (2002), Oliveira (2004) e Montaño et al. (2005).

Para os autores, o zoneamento ambiental não deve ser entendido apenas como o processo de parcelamento de um determinado espaço com o intuito de estabelecer os usos permitidos em sua ocupação. Envolve, acima de tudo, um comprometimento com uma política de desenvolvimento previamente estabelecida, tendo como função primária fornecer subsídios concretos para a aplicação desta política.

Neste sentido, a elaboração do zoneamento ambiental passa, fundamentalmente, pelo processo de determinação das vulnerabilidades e aptidões do território. Trata-se, portanto, de um instrumento cuja finalidade é auxiliar a formulação de políticas e estratégias de desenvolvimento e que possibilita a visualização da distribuição das áreas suscetíveis a processos naturais (tais como erosão do solo e assoreamento dos corpos d'água), bem como das áreas com maior potencial para a implantação de atividades de forma bastante clara.

Alguns autores têm relatado a utilização de uma abordagem semelhante, com um nível variável de inserção na estrutura institucional de seus países. A partir dos 
casos relatados a seguir, nota-se que a gestão territorial dos países mencionados é orientada, em algum momento e com diferentes posicionamentos na hierarquia de governo, por mecanismos de avaliação das vulnerabilidades e aptidões do território a ser ocupado, que se aproximam bastante daquilo que é entendido neste trabalho como sendo o papel fundamental do instrumento zoneamento ambiental.

$\mathrm{Na}$ Índia, a política de desenvolvimento industrial é orientada para a implantação de distritos industriais (Industrial Estates), como uma forma de se aproveitar ao máximo as vantagens oferecidas por este mecanismo (redução de custos de infra-estrutura e facilidades operacionais, principalmente), e procurando minimizar as suas desvantagens (sobretudo a ameaça ao meio ambiente relacionada aos resíduos gerados nas indústrias, e concentrados num distrito industrial). De acordo com SINGHAL \& KAPUR (2002), durante a implantação de distritos industriais, a escolha de áreas para a sua localização, o desenvolvimento das áreas industriais, e o fornecimento de serviços e infra-estrutura adequados são de responsabilidade dos governos estaduais, através de diferentes agências, dentre as quais uma das principais atribuições fica a cargo da CPCB (Central Pollution Control Board). Essa instituição é responsável pela elaboração de um atlas de zoneamento para suporte e simplificação do processo de tomada de decisão referente à escolha de locais para a implantação de indústrias. Num primeiro momento, observam-se os aspectos ambientais para a identificação de áreas com aptidão para o desenvolvimento de atividades industriais, para que somente então os aspectos "econômicos" (infra-estrutura, disponibilidade de mão-de-obra, matériaprima, facilidade de escoamento da produção, distância ao centro consumidor, etc.) sejam considerados. 
Di BONA (2000) faz menção a uma nova metodologia de planejamento do uso do solo, desenvolvida pela Charles River Watershed Association (algo como um comitê de bacia hidrográfica, sediada em Auburndale, Massachusetts, EUA), que busca integrar aos Planos Diretores tradicionais a preocupação com a sustentabilidade dos recursos hídricos. Este zoneamento ambiental (environmental zoning, nas palavras do autor) procura, acima de tudo, incluir no planejamento do uso do solo a observação do ciclo hidrológico, reconhecendo o recurso hídrico como um fator limitante ao crescimento. O processo, segue o autor, se inicia com a identificação de áreas aptas para a disposição de efluentes, de recarga e das regiões importantes para a proteção da qualidade das águas e, através de um processo que prevê a participação da comunidade envolvida por meio de consultas e reuniões, procura apresentar sugestões que complementem as leis de zoneamento locais.

Tem sido verificada uma melhora do recurso hídrico em termos qualitativos e quantitativos, fruto de um zoneamento legalmente amparado, elaborado com base em informações científicas e legitimado pela extensa participação pública. Para Di BONA (2000), este tipo de zoneamento permite às cidades um controle sobre o seu próprio destino, direcionando o desenvolvimento para as áreas realmente aptas a suportá-lo.

Carsjens e van der Knaap (2002) apresentam um trabalho fundamentado no fato de que as decisões a respeito de um determinado uso do solo numa localidade específica dependem, entre outras coisas, da aptidão do local a este uso. Para os autores, uma análise de aptidão pode revelar as diferentes potencialidades para o uso do solo e suas restrições, fornecendo um conjunto de dados objetivos que influenciam qualquer decisão tomada a respeito do uso sustentável do solo. 
Aplicado a uma porção do território holandês, o trabalho apresenta dois enfoques diferentes, em termos de escala: local e regional (esta, abrangendo uma área de $5.000 \mathrm{~km}^{2}$ ), cada qual com seus critérios específicos. Numa escala local, avaliou-se a influência para a aptidão ao desenvolvimento da atividade agropecuária dada pelas relações topológicas entre os elementos internos à unidade produtiva (farmlands), considerando a indústria de laticínios (dairy farming). Para a escala regional, foram consideradas as relações entre outras unidades produtivas, distância entre estas e as unidades de conservação, de recreação e infra-estrutura primária de acesso às instalações industriais (suinocultura). Os autores, inclusive, confrontam os resultados - mapas de aptidão para a atividade, específicos para cada critério considerado, integrados posteriormente através de avaliação multi-criterial - com as políticas governamentais para o setor.

O trabalho propõe uma metodologia de alocação de atividades econômicas (agricultura/laticínios) em função de critérios econômicos e ambientais, observandose a relação topológica entre os processos biofísicos e econômicos e a configuração espacial dos diferentes usos do solo.

Ainda conforme Carsjens e van der Knaap (2002), o mapa produzido em escala regional poderia ser utilizado num processo de planejamento para avaliar a demanda futura por áreas para a suinocultura, em combinação com diferentes demandas por outras categorias de uso do solo. Além disso, seguem os autores, a estruturação adequada das informações referentes às condições limitantes e das projeções para o setor permite a inclusão, em uma etapa inicial do processo de planejamento, de diferentes fatores intervenientes no processo.

As políticas públicas em relação às questões ambientais, além de balizarem a iniciativa pública ou privada em termos de ação, devem atender a um dos requisitos 
essenciais para que a gestão ocorra, qual seja, a responsabilidade do poder público em produzir a informação quando inexistente (art. 9º, inciso XI da Lei $n^{\circ}$. 6.938/81, Política Nacional do Meio Ambiente) e disponibilizá-la para a sociedade como um todo (artigo $6^{\circ}$, inciso VII, parágrafo $3^{\circ}$ da referida Lei).

Portanto, como instrumento de apoio ao executor das políticas públicas, também caberia ao zoneamento ambiental contribuir para a produção de informações dinâmicas que auxiliem no controle e manutenção da qualidade ambiental.

Nesse contexto, pode-se identificar a necessidade da incorporação de ferramentas que permitam agregar novas informações ao processo de elaboração de políticas de desenvolvimento territoriais, com base nos diferentes instrumentos existentes - zoneamento ambiental, inclusive. Como mecanismo de visualização de cenários alternativos de desenvolvimento, a modelagem das alterações no uso e ocupação do solo pode suprir de modo satisfatório tal necessidade.

$\mathrm{Na}$ geração e avaliação de mapas obtidos a partir da modelagem das alterações de uso e ocupação do solo, conforme de Nijs et al. (2004), cada mapa elaborado não representa necessariamente a evolução do desenvolvimento do território avaliado, mas sim as possíveis alterações no uso do solo, caso as tendências identificadas para aquele território, num certo instante, sejam mantidas de modo a se desenvolverem de acordo com um cenário projetado. Trazem, segundo os autores, informações valiosas para uma avaliação dos efeitos potenciais sobre os recursos naturais e sobre a paisagem a partir das tendências e do comportamento identificados para a sociedade. 


\subsection{Modelagem para avaliação da alteração do uso e cobertura do solo - fundamentos e aplicações na gestão ambiental}

Dentre as necessidades específicas dos agentes envolvidos com a gestão ambiental de um determinado território, quais sejam, os administradores públicos e privados, os planejadores e a sociedade em geral, a existência de informações que permitam equacionar as demandas de cada setor envolvido no processo decisório é fundamental, na perspectiva de compatibilizar as exigências do desenvolvimento (econômico, social) com a manutenção ou melhoria da qualidade ambiental e de vida.

Para que se consiga tal compatibilização, além de direcionar de modo adequado as discussões relacionadas às conseqüências deste desenvolvimento, é necessário ter em mãos ferramentas que permitam aos tomadores de decisão integrar e avaliar a ampla gama de informações disponíveis e que forneçam respostas confiáveis, relacionadas principalmente às implicações decorrentes das alterações do uso e cobertura do solo $^{4}$ - considerando o efeito combinado das políticas de desenvolvimento, do comportamento humano, do mercado e outros fatores que direcionam essas alterações (USEPA, 2000).

De acordo com a Agência de Proteção Ambiental dos Estados Unidos (USEPA, 2000) a modelagem da alteração no uso da terra é um componente fundamental para a visualização e avaliação das conseqüências e implicações de decisões políticas e ações que venham a modificar os padrões de ocupação do território. A

\footnotetext{
${ }^{4}$ Para Turner et al. (1991), uso do solo se refere aos propósitos humanos - agricultura, indústria, preservação, etc. - associados a uma determinada cobertura (ou ocupação) do solo, que vem a ser tão somente a caracterização da superfície terrestre - floresta, água, área construída. Naturalmente, uma única classe de uso pode comportar diversas categorias de cobertura ou ocupação, e vice-versa.
} 
esse respeito, Farrow e Winograd (2001) afirmam que a identificação de tendências e o estabelecimento de cenários futuros de ocupação são mecanismos essenciais para a formulação de políticas que atuem de forma preventiva, no sentido de incentivar ou evitar tais tendências.

Conforme Pontius Jr. e Schneider (2001), a comunidade científica internacional vem sendo instada há algum tempo a pesquisar a dinâmica das alterações no uso do solo, visando particularmente o desenvolvimento de modelos de previsão para os padrões espaciais de alterações futuras (conhecidos como modelos LUCC - da sigla em inglês Land-Use and Cover Change).

Como conseqüência, diversas instituições de ensino e pesquisa em todo o globo têm se esforçado no sentido de disponibilizar métodos e modelos que permitam a avaliação das modificações nos padrões de uso do solo. Em recentes relatórios publicados por duas instituições governamentais norte-americanas (EPA Environmental Protection Agency e USDA - United States Department of Agriculture) são avaliados nada menos do que 37 modelos de previsão de alteração do uso do solo, 10 dos quais desenvolvidos por consultores privados (USEPA, 2000; AGARWAL et al, 2002).

Vale destacar que a revisão bibliográfica efetuada ao longo da elaboração do presente trabalho evidencia a existência de um número ainda maior, dada a quantidade de modelos encontrados na literatura e que não são citados nos relatórios mencionados, o que indica que esta área de pesquisa encontra-se em pleno desenvolvimento.

Além disso, Jäger (2003) menciona um extenso programa de cooperação científica internacional, vinculado atualmente ao Conselho Internacional para a Ciência (International Council for Science - ICSU), dedicado a promover e coordenar 
pesquisas com o intuito de descrever, analisar e entender as dimensões humanas das alterações no ambiente global. O International Human Dimensions Programme on Global Environmental Change (IHDP) destaca entre seus quatro núcleos principais, segundo a autora, um projeto de pesquisa que investiga justamente os fatores físicos e humanos que atuam (physical and human driving forces) sobre os processos de modificação no uso e ocupação do solo. Um dos focos de investigação desse projeto (denominado Projeto LUCC) reside no desenvolvimento de modelos que forneçam uma base para a projeção das alterações futuras no uso do solo e para a melhor compreensão dos fatores que condicionam tais alterações.

O Brasil experimenta um processo semelhante, por meio de uma cooperação técnico-científica entre o Ministério da Ciência e Tecnologia (MCT) e um grupo de instituições brasileiras de pesquisa e desenvolvimento estabelecidos no ano de 2002. A Rede Temática de Pesquisa em Modelagem Ambiental da Amazônia (GEOMA) tem como objetivos, dentre outros, "desenvolver modelos computacionais capazes de predizer a dinâmica dos sistemas ecológicos e sócio-econômicos em diferentes escalas geográficas, dentro do conceito de sustentabilidade; auxiliar a tomada de decisão nos níveis local, regional e nacional' (MCT, 2002).

Uma das áreas de pesquisa da rede (Modelagem de Mudanças de Uso e Cobertura da Terra), a ser desenvolvida até o ano de 2006, prevê a produção de modelos diagnósticos e prognósticos ${ }^{5}$ sobre o processo de ocupação na Amazônia, e o desenvolvimento de cenários de ocupação baseados nos modelos prognósticos produzidos (MCT, 2002).

\footnotetext{
${ }^{5}$ Conforme o significado dos termos, aplicam-se respectivamente a explicar uma determinada situação e a prever (ou antecipar) uma situação futura, baseados em certos condicionantes. Para um detalhamento referente aos diferentes tipos de modelos veja a extensa descrição feita por Briassoulis (2000, livro on-line).
} 


\subsubsection{Aplicações}

Segundo Lambin (1994) ${ }^{6}$ apud Pedrosa (2003), a modelagem da evolução de padrões espaciais deve procurar identificar as variáveis ambientais e culturais que contribuem para explicar o fenômeno em questão, bem como quais são os processos ecológicos e sócio-econômicos que o condicionam, além de explicar como o processo evolui e onde ocorre (ou ocorrerá) tal fenômeno.

Para Pontius Jr. e Malanson (2005), a escolha sobre qual modelo empregar para uma dada aplicação no tempo e no espaço é uma tarefa difícil, que depende fundamentalmente dos propósitos associados à modelagem que se pretende efetuar, levando-se em consideração a necessidade - quaisquer que sejam os propósitos da modelagem - de que o comportamento do modelo seja similar ao do sistema real, ou ainda, que o modelo tenha alguma capacidade preditiva.

Aspinall (2004) destaca, entre as principais abordagens para a modelagem do uso e ocupação do território: modelos estocásticos baseados em matrizes de transição (por exemplo, cadeias de Markov); modelos de otimização (que incluem modelos sócio-econômicos de oferta e demanda, programação multi-objetivo); modelos dinâmicos de simulação baseados em processos (como os modelos autômatos celulares) e modelos de simulação baseados em agentes (que incorporam tanto os modelos estocásticos quanto os modelos baseados em processos); e modelos empíricos.

De acordo com Aspinall (2004), o estudo das modificações no uso do solo tem sido amplamente realizado valendo-se de modelos empíricos. Para a alimentação

\footnotetext{
${ }^{6}$ LAMBIN, E. F. (1994). Modeling deforestation processes: a review. TREES series B: Research Report, European Commission, EUR 15744 EN. Luxembourg: Office of Official Publications of the European Community.
} 
destes modelos, segue o autor, comumente são empregadas metodologias de regressão a partir de um conjunto de dados históricos que descrevem os padrões de uso e ocupação do território estudado.

Segundo Lambin (1994, op. cit.) apud Pedrosa (2003), modelos empíricos procuram focar o relacionamento entre as variáveis do modelo, supondo que os relacionamentos observados no passado se manterão no futuro. Diretamente relacionados aos interesses do presente trabalho, os modelos empíricos caracterizam-se por apresentar três componentes-chave: uma configuração inicial (obtida através de dados históricos do fenômeno em estudo), uma configuração de mudança e uma configuração de saída (PEDROSA, 2003).

A literatura especializada registra muitos exemplos de aplicação de modelos para a avaliação das alterações no uso do solo, com predominância para os modelos empíricos, e particularmente para os modelos baseados em metodologias de regressão. Percebe-se, inclusive, uma grande quantidade de trabalhos que empregam modelos empíricos em aplicações diferentes daquelas para as quais foram desenvolvidos originalmente. A título de ilustração, é feito um breve comentário de algumas aplicações que utilizam uma abordagem semelhante à do presente trabalho.

Schneider e Pontius Jr. (2001) comparam o emprego de regressão logística e de avaliação multi-criterial na obtenção de mapas de tendência ao desflorestamento para a bacia do Rio Ipswich (Massachusetts, EUA). Concluem que ambas apresentam resultados altamente dependentes do conjunto de variáveis utilizadas para a explicação do fenômeno estudado (tendência ao desflorestamento), que no caso do trabalho era composto pelas variáveis: declividade, elevação e distância às áreas urbanizadas. 
Pontius Jr. et al. (2001) apresentam o modelo GEOMOD2 para a previsão das áreas mais sujeitas ao desflorestamento na Costa Rica. Baseado em informações de uso do solo e outros fatores biogeofísicos, referentes aos anos de 1940, 1961 e 1983, o modelo determina de modo empírico quais são os atributos com mais tendência ao desflorestamento para em seguida projetar a espacialização para o ano de 2010. Segundo os autores, o modelo foi desenvolvido para explicitar a localização dos fenômenos avaliados, procurando suprir uma lacuna existente na atual geração de modelos LUCC. Isso faz com que seja necessário utilizar outros recursos para a projeção da quantificação das alterações futuras. Além disso, é colocado como uma vantagem o fato de ter sido desenvolvido para aplicações em locais em que há limitações nos dados disponíveis (uma vez que requer como entrada apenas um único mapa de uso e ocupação do solo), como no caso das regiões tropicais, podendo ser adaptado para outras regiões. De fato, o modelo tem sido empregado para a avaliação de alterações no uso do solo em situações diversas, como no caso das Ghats Ocidentais - Índia (PONTIUS e PACHECO, 2004) e para avaliação da expansão urbana na região central de Massachusetts, EUA (PONTIUS e MALANSON, 2005).

Silva e Clarke (2002) descrevem o emprego do modelo SLEUTH (CLARKE e GAIDOS, 1998) para a modelagem da expansão das áreas metropolitanas de Lisboa e Porto, Portugal. Após a calibração do modelo (desenvolvido originalmente para a cidade de São Francisco, EUA), o trabalho apresenta a previsão, para o ano de 2025, para a distribuição espacial das duas áreas avaliadas, recomendando a realização de uma investigação que avalie os impactos do crescimento previsto sobre o planejamento territorial e de transportes. 
Hathout (2002) descreve o impacto sobre as áreas agricultáveis do crescimento urbano concentrado na zona de transição urbano-rural, comparando as taxas de alteração observadas para as categorias "urbano", "rural" e "outros", em dois municípios canadenses no período entre 1960 e 1989 com a taxa de crescimento (para o mesmo período) prevista por meio da aplicação da cadeia de Markov. Após a validação da metodologia, o trabalho realiza uma simulação para o período 19902007, aplicada aos dois municípios para a avaliação da conversão entre o uso rural e urbano. Destacando o fato de que tanto as alterações reais na área construída quanto as previsões para as modificações no uso do solo efetuadas poderem ser explicadas como sendo resultado de fatores "externos" (alterações nos custos de construção em área urbana, sua disponibilidade ao longo das vias principais, melhoria na infra-estrutura da área), o trabalho indica que o padrão da expansão urbana na zona de transição urbano-rural é dado pela descontinuidade com a malha urbana existente.

Almeida (2003) apresenta um trabalho que aplica o modelo de autômatos celulares DINAMICA, desenvolvido pelo Centro de Sensoriamento Remoto da Universidade Federal de Minas Gerais (CSR-UFMG), baseado em algoritmos de transição estocásticos. O trabalho simula as alterações no uso do solo urbano para duas cidades de médio porte paulistas (Bauru e Piracicaba), apresentando os resultados obtidos para os períodos de 2000-2004 e 2000-2007. A determinação das probabilidades de transição de uso do solo foi feita pelo método de regressão logística, e a quantificação das áreas para os cenários futuros empregou um modelo de transição Markoviano. Ao final, a autora propõe a utilização dessa abordagem nos processos de planejamento urbano, sobretudo no que diz respeito à adequação da infra-estrutura urbana às demandas futuras. 
Verburg e Veldkamp (2004) aplicam o modelo CLUE-s (VERBURG et al., 2002) para a modelagem das tendências de alteração no uso do solo para duas áreas nas Filipinas, e para a avaliação de dois cenários para o ano de 2010 (para a área total do arquipélago, com dados em escala 1:250.000) e 2019 (para a ilha Sibuyan, com dados em escala 1:10.000) que consideram a manutenção ou a modificação das tendências atuais de ocupação. O modelo CLUE-s faz uso de regressão logística para a determinação da probabilidade de ocorrência do fenômeno considerado (conversão de áreas de floresta em agricultura ou em áreas desmatadas pela exploração de madeira). O trabalho indica que o potencial de exploração dos resultados obtidos varia conforme a escala de trabalho utilizada, o que implica numa avaliação em diferentes escalas conforme as necessidades dos tomadores de decisão.

O trabalho de De Nijs et al. (2004) avalia a influência sobre o meio ambiente de um cenário alternativo em termos de desenvolvimento sócio-econômico e demográfico para o território holandês, valendo-se de ferramentas de geoprocessamento e modelagem que possibilitaram a elaboração de um mapa de uso e ocupação do solo projetado para o ano de 2030 , por meio de um modelo que aplica a teoria dos autômatos celulares, denominado Environment Explorer. O artigo apresenta a metodologia empregada para a elaboração desta projeção, considerando um cenário caracterizado por uma sociedade altamente globalizada, que tem o governo se retirando de muitas áreas, o planejamento espacial dominado pelos princípios de mercado, e as políticas de restrição à ocupação urbana eliminadas, abrindo caminho para a expansão urbana fragmentada e descontínua, especialmente pequenos aglomerados em área rural. 
Lima, Santos e Silva (2005) aplicam a modelagem por autômatos celulares e redes neurais artificiais para estimar os custos futuros de transporte, em função da redistribuição (quantitativa e espacial) da demanda para o ano de 2010, por equipamentos coletivos como creches e escolas infantis, na cidade de São Carlos $(\mathrm{SP})$. Os autores mencionam que as informações provenientes da modelagem efetuada são úteis para o planejamento da infra-estrutura urbana, dada a capacidade dos modelos em simular diferentes padrões de ocupação territorial. 


\section{MATERIAIS E MÉTODOS}

\subsection{Delimitação e caracterização da área de estudo}

A primeira etapa do trabalho consiste na delimitação da área de estudo e identificação dos possíveis recortes territoriais para a aplicação do modelo de projeção.

Em virtude do objetivo geral do trabalho, dos dados disponíveis, e tendo em vista as necessidades (em termos de capacidade de processamento de dados ${ }^{7}$ ) do modelo empregado no presente trabalho, optou-se por gerar um recorte que envolvesse a área composta pela união do Perímetro Urbano com a Zona de Expansão Urbana, conforme discriminados na proposta de Plano Diretor elaborada para o município de São Carlos (SÃO CARLOS, 2004), recentemente submetido e aprovado pelo Legislativo municipal. Tal recorte, correspondendo a aproximadamente $615 \mathrm{~km}^{2}$ (figura 2) foi trabalhado em ambiente digital adotando-se células de 60x60 metros.

\footnotetext{
7 As primeiras tentativas de se aplicar o modelo para todo o território do município $-1040 \mathrm{~km}^{2}$ aproximadamente - foram nitidamente prejudicadas pela incapacidade do sistema computacional utilizado em processar o volume de dados correspondente - que depende da extensão do território em estudo e da resolução espacial adotada (tamanho da célula que compõe as imagens trabalhadas).
} 

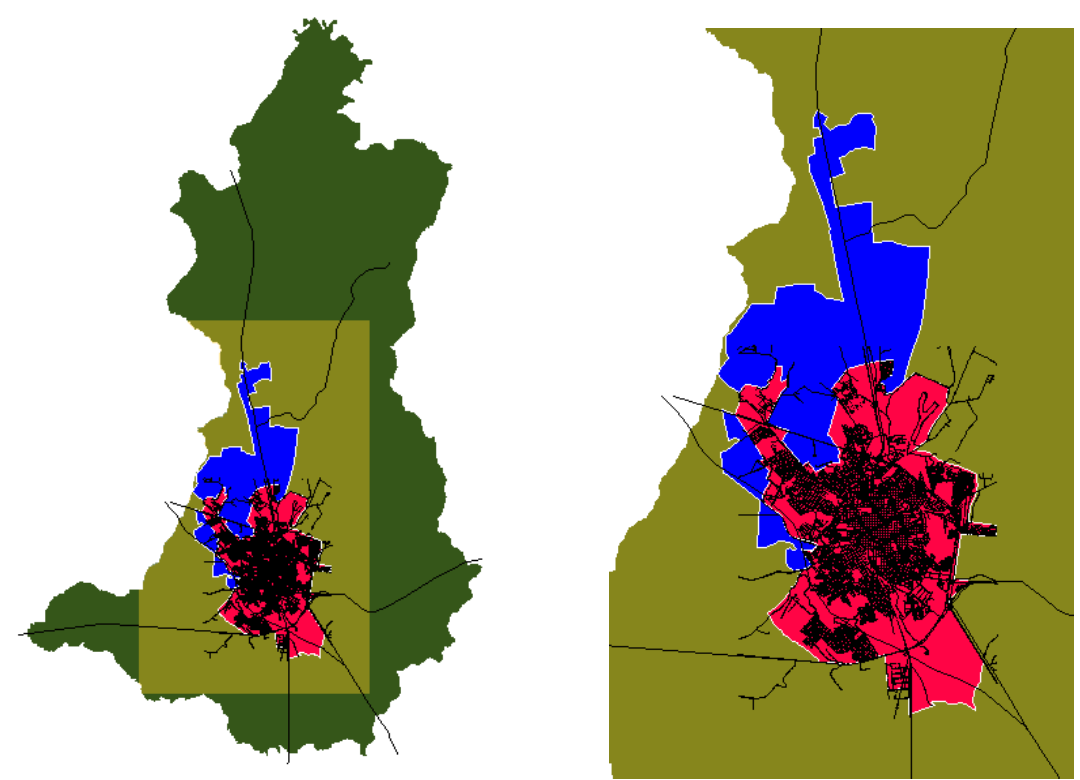

Figura 2. Recorte adotado para o presente trabalho, em relação ao município de São Carlos (esq.) e detalhamento sobre o recorte (dir.). Perímetro urbano (vermelho) e Zona de Expansão Urbana (azul), delimitados conforme SÃO CARLOS, 2004.

São Carlos é um município da região central do Estado de São Paulo (figura 3), que ocupa uma superfície de $1.132 \mathrm{~km}^{2}$, com uma população superior a 210.000 habitantes, e que apresenta altas taxas de urbanização (96\%) e de crescimento populacional $(2,07 \% \text {, para o período } 2000-2005)^{8}$.

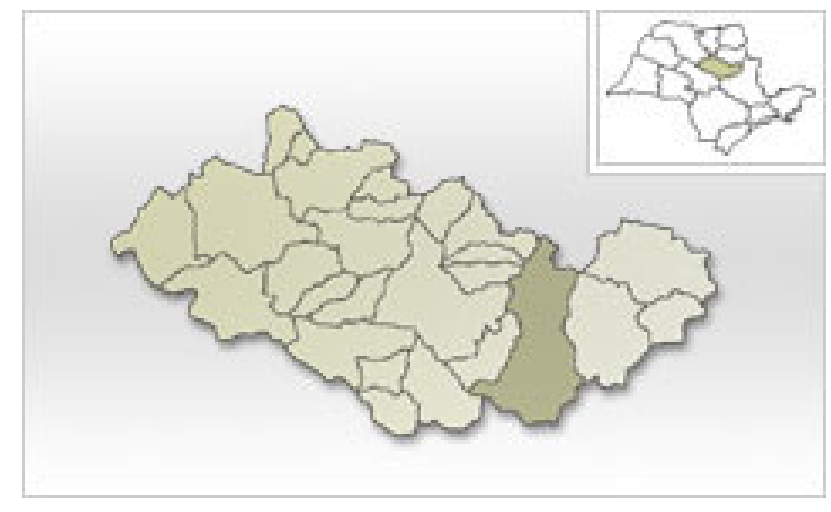

Figura 3. Localização do município de São Carlos, em relação ao Estado de São Paulo, e à Região Administrativa Central (fonte: Fundação Sistema Estadual de Análise de Dados - SEADE).

\footnotetext{
${ }^{8}$ Dados para o ano de 2005, de acordo com o "Perfil Municipal de São Carlos", elaborado pela Fundação SEADE. < http://www.seade.gov.br/produtos/perfil/>
} 
Conforme Dozena (2001), trata-se de uma cidade que está em constante transformação, sobretudo na área urbana, devido à existência de um grande número de indústrias (de grande a pequeno porte). Caracterizada por ser um importante centro educacional e de pesquisa, constitui um pólo tecnológico bastante dinâmico (caracterizado, segundo o autor, pela concentração de pequenas e médias empresas - centros de pesquisa e/ou estabelecimentos industriais - de alta tecnologia, inovadoras, geralmente associadas a Universidades, e centros de pesquisa).

\subsection{Materiais}

Para a realização do presente trabalho, foram utilizados os seguintes materiais:

$\checkmark$ composições coloridas RGB de imagens dos satélites LANDSAT 5, órbitaponto 220_75, datadas março de 1998 (sensor TM, RGB342, resolução espacial de 30 metros) e CBERS-2, mosaico entre as órbitas-ponto 156_124

e 156_125, datadas de maio de 2005 (sensor CCD, RGB243, resolução espacial de 20 metros);

$\checkmark$ arquivos vetoriais (digitais) provenientes do acervo do Laboratório de Sistemas de Informação Geográfica, LabSIG, do Departamento de Hidráulica e Saneamento da EESC/USP, contendo as informações de topografia, infra-estrutura viária e hidrografia (escala 1:50.000), tipos de solo (escala 1:100.000) e geologia (1:250.000);

$\checkmark$ mapa cadastral (em formato vetorial) com informações do sistema viário, loteamentos urbanos e rurais, localização dos campi universitários (USP e 
UFSCar), disponibilizado pela Prefeitura Municipal de São Carlos, elaborado em escala 1:50.000;

$\checkmark$ arquivo vetorial elaborado pelo Laboratório de Planejamento Ambiental da Universidade Federal de São Carlos (LAPA-UFSCar) e disponibilizado pela Prefeitura Municipal de São Carlos, discriminando as áreas de reserva legal averbadas no município, para o ano de 2002;

$\checkmark$ arquivo vetorial disponibilizado pelo Instituto Nacional de Pesquisas Espaciais - INPE contendo a delimitação da unidade de pesquisa da EMBRAPA Pecuária Sudeste (Fazenda Canchim, em São Carlos);

$\checkmark$ Sistema de Informações Geográficas SIG IDRISI, versão 14.02 Kilimanjaro, desenvolvido pela Clark Labs, Clark University, EUA. Especificamente, foram empregados na modelagem os módulos de projeção por Cadeia de Markov (MARKOV), regressão logística (LOGISTICREG), estatísticas de semelhança entre imagens (VALIDATE), e o modelo Geomod de projeção da alteração do uso do solo (GEOMOD).

Toda a informação cartográfica foi trabalhada georeferenciada para o sistema de projeção UTM, datum Córrego Alegre.

\subsection{Descrição da metodologia}

Em função de seus objetivos específicos, o trabalho foi executado em duas frentes distintas entre si, integradas pela busca do objetivo geral.

Uma dessas frentes modela as tendências atuais de urbanização do território (considerando o período 1998-2005, e não incluindo na análise os distritos de Água 
Vermelha e Santa Eudóxia) e apresenta a situação projetada para duas datas futuras (2012 e 2019).

Uma segunda frente de trabalho elabora e apresenta uma ponderação sobre fatores ambientais que é empregada como base metodológica para a avaliação da aptidão (em termos de viabilidade ambiental) do território estudado quanto à sua urbanização (denominado aqui de Zoneamento Ambiental para Ocupação Urbana).

De forma geral, a realização destas duas frentes observou o esquema apresentado na figura 4 .

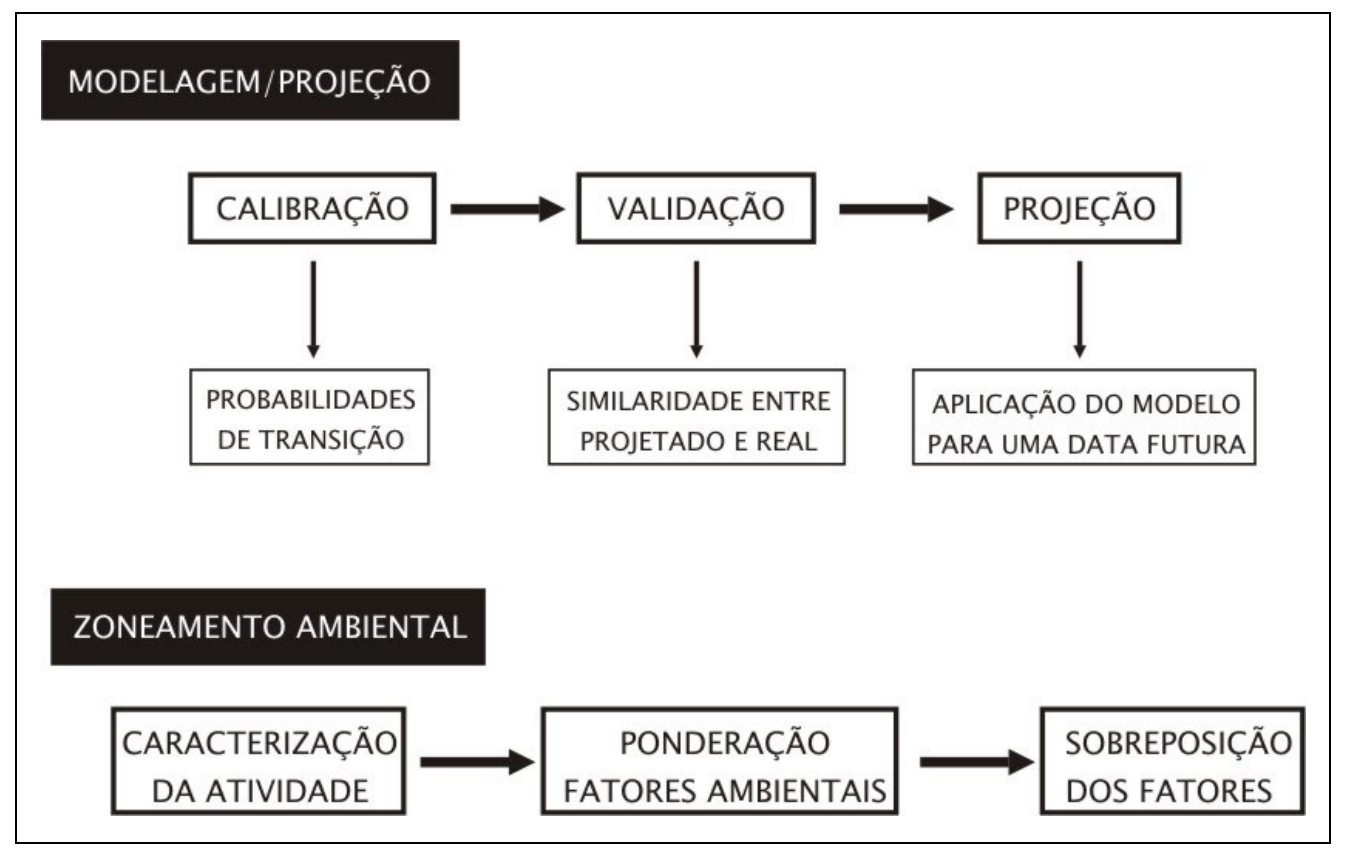

Figura 4. Esquema simplificado para a realização da modelagem e do zoneamento ambiental 


\subsubsection{Descrição dos procedimentos de modelagem e projeção da expansão urbana}

A modelagem da expansão urbana, efetuada para o município de São Carlos, se ampara em diferentes elementos aplicados em modelagem de alteração de uso e ocupação do solo, disponibilizados pelo software IDRISI v. 14.02 Kilimanjaro (plataforma básica empregada pelo LabSIG/SHS, núcleo de pesquisa em que foi desenvolvida a presente Tese de Doutorado). Vale dizer que o modelo empregado, Geomod, foi desenvolvido na mesma Universidade que desenvolve o software IDRISI (Clark University), tendo sido integrado à atual versão do mesmo.

Conforme Eastman (2003) o modelo GEOMOD tem a habilidade de prever a transição de uma categoria de uso do solo (no estado 1) para outra (no estado 2), especificamente quanto à localização das células que irão sofrer essa alteração de estados em um dado intervalo de tempo.

A simulação com o GEOMOD é baseada em:

$\checkmark$ Especificação do instante inicial, instante final e do intervalo de tempo para a simulação;

$\checkmark$ Uma imagem de uso do solo indicando a localização dos estados 1 e 2 para o instante inicial;

$\checkmark$ Um mapa que indique a probabilidade de transição das células para o estado 2;

$\checkmark$ A quantidade de células nos estados 1 e 2, para o instante final de simulação. 
Uma característica básica do modelo aplicado (Geomod) é a simulação das transições entre apenas dois estados. No caso do presente trabalho, a modelagem é efetuada para simular a transição de áreas não-urbanas (estado 1) para urbanas (estado 2).

Tendo em vista a possibilidade de se definir com precisão adequada, para as necessidades do presente trabalho, os limites da ocupação urbana, a partir das imagens de satélite disponíveis, tais limites foram delimitados diretamente sobre as imagens, para a elaboração de mapas que apresentassem somente as categorias NÃO-URBANA (Estado 1) e URBANA (Estado 2). Esse procedimento foi efetuado para as duas datas (1998 e 2005), conforme figura 5.
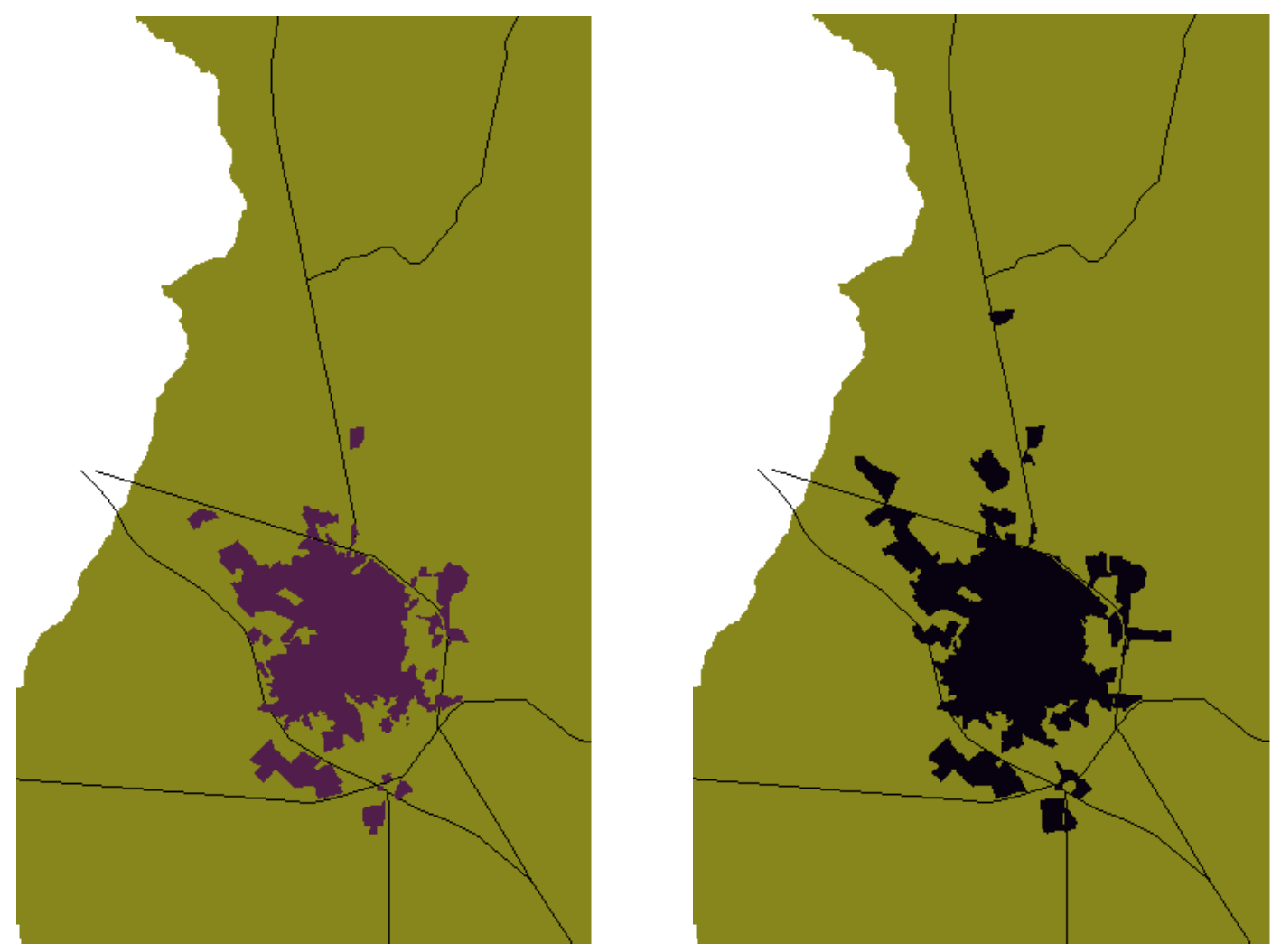

Figura 5. Área urbana em 1998 (esq.) e 2005 (dir.)

Modelos de simulação das alterações no uso e ocupação do solo geralmente partem das condições iniciais observadas em um território no instante $t_{1}$, para então 
simular as condições para um instante $t_{2}$. Essa previsão deve ser comparada a um mapa de referência, que corresponde à situação real no instante $t_{2}$, para que seja avaliado o desempenho do modelo.

Tal fato demanda alguns procedimentos básicos de calibração, validação e previsão, que envolvem o tratamento e sistematização dos dados, de modo a potencializar os resultados obtidos com a aplicação do modelo.

\subsubsection{1 $\underline{\text { Calibração }}$}

O procedimento de calibração tem por finalidade a determinação das probabilidades de transição do estado 1 para o estado 2 a partir de um conjunto de variáveis consideradas adequadas para a explicação do fenômeno modelado.

Pontius e Pacheco (2004) afirmam que a determinação dos padrões de alteração do uso da terra não possui uma técnica padronizada, e sim várias técnicas que podem ser aplicadas, sendo que as mais comuns recaem sobre avaliação multicritério (MCE) e regressão logística. Ambas procuram estabelecer uma relação entre a variável dependente (no caso do presente trabalho, área urbana) e algumas variáveis independentes.

No caso do presente trabalho, o mapa de probabilidades de transição de estados foi elaborado por meio do método de regressão logística binomial, conforme Schneider e Pontius Jr. (2001) e Eastman (2003). Essa operação é efetuada pelo módulo LOGISTICREG, disponibilizado pelo software IDRISI.

A regressão logística binomial é aplicada a dados de natureza binária, que podem assumir apenas dois valores (presença ou não-presença do fenômeno 
estudado). Tal regressão é usualmente empregada para descrever a relação entre uma variável dependente (no caso, a transição de área não-urbana para urbana) e uma ou mais variáveis independentes (que "explicam" o fenômeno), assumindo que a probabilidade da variável dependente apresentar o fenômeno em questão (ou seja, apresentar o valor 1) segue uma curva logística ${ }^{9}$, conforme Aldrich e Forrest $(1984)^{10}$ apud Eastman (2003).

A figura 6 ilustra o procedimento de calibração para a modelagem efetuada.

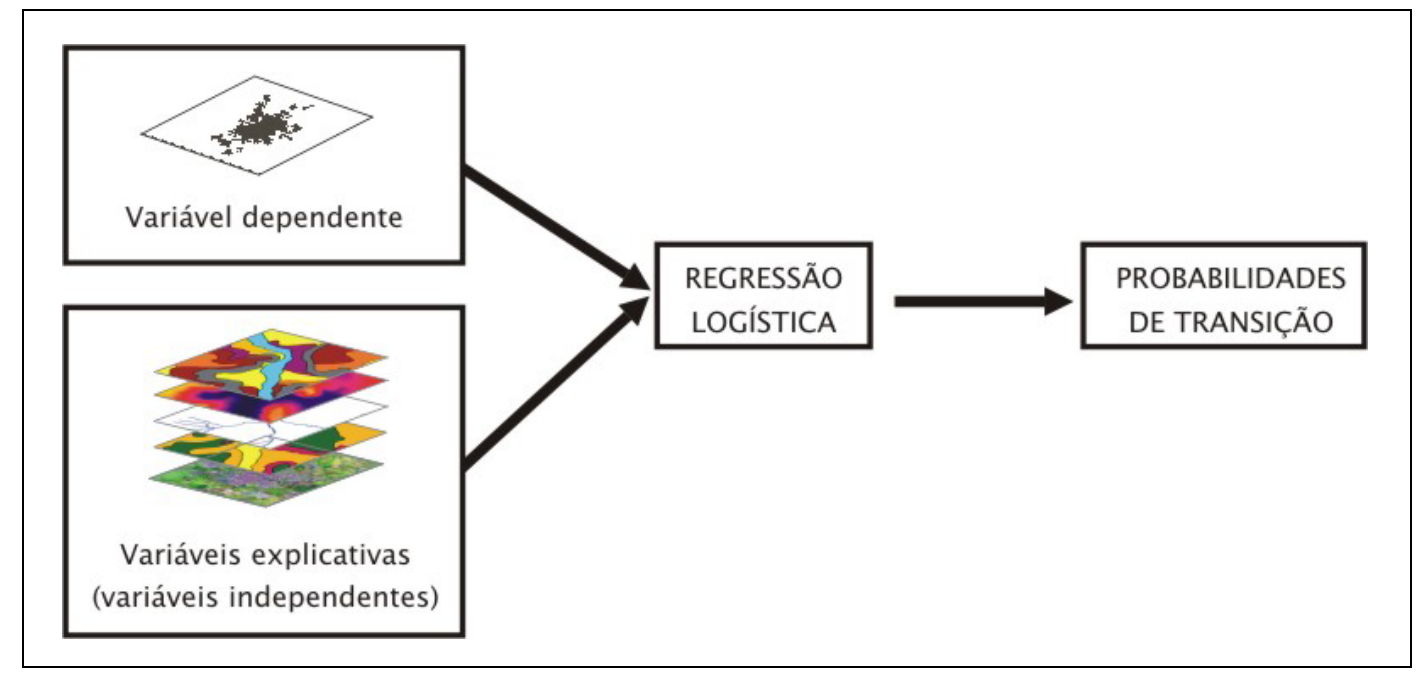

Figura 6. Procedimento de calibração

O módulo LOGISTICREG foi alimentado com os seguintes parâmetros:

Variável dependente - variação da expansão urbana entre $1998\left(t_{1}\right)$ e $2005\left(t_{2}\right)$;

\footnotetext{
${ }^{9}$ A regressão logística binomial descreve a probabilidade de $\mathrm{Y}$ (variável dependente) assumir valor 1 , dado o conjunto de variáveis dependentes $(X)$ como:

em que:

$$
\mathrm{P}(\mathrm{Y}=1 / X)=\frac{\exp (\Sigma B X)}{1+\exp (\Sigma B X)}
$$

P é a probabilidade de Y assumir valor 1;

$X$ é o conjunto de variáveis independentes $\left(\mathrm{x}_{1}, \mathrm{x}_{2}, \mathrm{x}_{3}, \ldots, \mathrm{x}_{\mathrm{k}}\right)$;

$B$ é o conjunto dos coeficientes estimados para o ajuste $\left(\mathrm{b}_{0}, \mathrm{~b}_{1}, \mathrm{~b}_{2}, \mathrm{~b}_{3}, \ldots, \mathrm{b}_{\mathrm{k}}\right)$

O procedimento envolve ainda a linearização da equação anterior através da transformação logística (ou logit): $\mathrm{P}^{\prime}=\ln (\mathrm{P} / 1+\mathrm{P})=\mathrm{b}_{0}+\mathrm{b}_{1} \cdot \mathrm{x}_{1}+\mathrm{b}_{2} \cdot \mathrm{x}_{2}+\ldots .+\mathrm{b}_{\mathrm{k}} \cdot \mathrm{x}_{\mathrm{k}}+$ erro

10 ALDRICH, J. H.; FORREST, D. N. (1984). Linear, Probability, Logit, and Probit Models (in Series L Quantitative Applications in the Social Sciences). Newbury Park: Sage University Publication.
} 
Variáveis independentes - com base na revisão bibliográfica, e em função dos dados disponíveis, foram elencadas as seguintes variáveis:

$\checkmark$ tipos de solo;

$\checkmark$ declividade do terreno;

$\checkmark$ altitude;

$\checkmark$ distância a rodovias no instante $t_{1}$;

$\checkmark$ distância a vias de acesso (acesso às rodovias e acesso a outras regiões da cidade, ainda não ocupadas) no instante $t_{1}$;

$\checkmark$ distância a empreendimentos "atratores", cuja presença poderia induzir à ocupação da área ao seu redor: tendo em vista o perfil do município (cujas atividades econômicas desenvolvidas em área urbana são em grande medida condicionadas pelos setores industrial e de ensino universitário) considerou-se, nesse caso, o campus da Universidade Federal de São Carlos, uma grande indústria de compressores (TECUMSEH), uma indústria de motores (Volkswagen) e os aglomerados industriais inseridos na área urbana (Distrito Industrial Miguel Abdelnur e Centro Empresarial de Alta Tecnologia - CEAT);

distância à área urbana no instante $t_{1}$. 
Verificação do relacionamento das variáveis independentes com 0 fenômeno

A relação de cada variável independente com a expansão urbana no período 1998-2005 (variável dependente) foi verificada observando-se o histograma ${ }^{11}$ dos mapas resultantes do procedimento de multiplicação entre cada mapa para a variável investigada e o mapa gerado para a expansão urbana do período ${ }^{12}$. A observação do histograma permite concluir se existe um relacionamento direto e ordenado entre a expansão urbana e cada variável em análise (se há, por exemplo, uma predominância da expansão urbana em função da distância a rodovias, ou de acordo com a declividade, etc.).

Desempenho das combinações entre as variáveis independentes para a geração do mapa de probabilidades de transição

A partir da definição do conjunto de variáveis independentes selecionado para ser empregado na regressão logística (composto por 5 variáveis), procedeu-se à identificação das melhores combinações entre as variáveis independentes empregadas na regressão logística binomial, dentre todas as combinações possíveis. A finalidade desse procedimento é selecionar os melhores mapas de probabilidades de transição para alimentarem o modelo.

\footnotetext{
${ }^{11}$ Histograma, ou gráfico de freqüência, é um gráfico que apresenta a distribuição dos valores de um espaço amostral. No caso em questão, indica a quantidade de células da variável avaliada que apresenta o fenômeno da expansão urbana.

${ }^{12} \mathrm{O}$ fato do mapa para a expansão urbana ser do tipo booleano (ou seja, só apresenta valores 0 ou 1 ) faz com que o arquivo resultante da multiplicação efetuada apresente o "recorte" dos mapas de cada variável, sobre a expansão urbana. Esse procedimento também é descrito como "mascarar o mapa" de cada variável investigada (e, analogamente, o mapa booleano empregado na multiplicação é a "máscara").
} 
O módulo LOGISTICREG apresenta como saída, além da equação (linearizada) que define o mapa de probabilidades de transição do estado 1 para o estado 2, uma série de parâmetros estatísticos que permitem a avaliação do desempenho de cada combinação. Os resultados para o coeficiente de determinação ${ }^{13} R^{2}$ (que na verdade é denominado pelo módulo como pseudo- $R^{2}$, por conta da linearização efetuada na equação logarítmica), ROC (Relative Operating Characteristic) e para a qualidade do ajuste (goodness-of-fit) são empregados para avaliar o desempenho de cada combinação entre as variáveis. Segundo a documentação do software IDRISI:

$\checkmark$ "Pseudo- $R^{2}$ maior que 0,2 é considerado um ajuste relativamente bom" (CLARK e HOSKING, $1986^{14}$ apud EASTMAN, 2003);

$\checkmark$ "ROC é um excelente método para comparar um mapa booleano da 'realidade' e um mapa de probabilidades de transição. Sendo assim, ROC é uma excelente informação estatística para medir o sucesso no ajuste de uma regressão logística. Os valores para $R O C$ variam entre 0 e 1, em que 1 indica um ajuste perfeito e 0,5 indica um ajuste aleatório" (EASTMAN, 2003);

$\checkmark$ "A qualidade do ajuste é determinada pela diferença entre os valores observados e os valores previstos para a variável dependente (sendo que valores pequenos indicam um melhor ajuste)”. (EASTMAN, 2003)

Para todas as combinações de variáveis possível, o resultado obtido com o LOGISTICREG foi avaliado, selecionando-se as melhores combinações em termos

\footnotetext{
${ }^{13} \mathrm{O}$ coeficiente de determinação, $\mathrm{R}^{2}$, é uma medida da proporção da variabilidade em uma variável que é explicada pela variabilidade da outra.

${ }^{14}$ CLARK, W. A.; HOSKING, P.L. (1986). Statistical Methods for Geographers (Chapter 13). New York: John Wiley \& Sons.
} 
de pseudo $\mathrm{R}^{2}$, ROC e goodness-of-fit, para serem utilizadas como parâmetro de entrada durante a validação do modelo ${ }^{15}$.

\subsubsection{Validação}

A partir das probabilidades de transição, aplica-se o modelo para a obtenção de um mapa simulado para o instante $t_{2}$, comparando-o com um mapa "empírico" (real) do mesmo instante (figura 7). A validação é necessária para demonstrar que o modelo aplicado é consistente e compatível com a finalidade da modelagem efetuada, no sentido de se aplicar o modelo para um instante futuro.

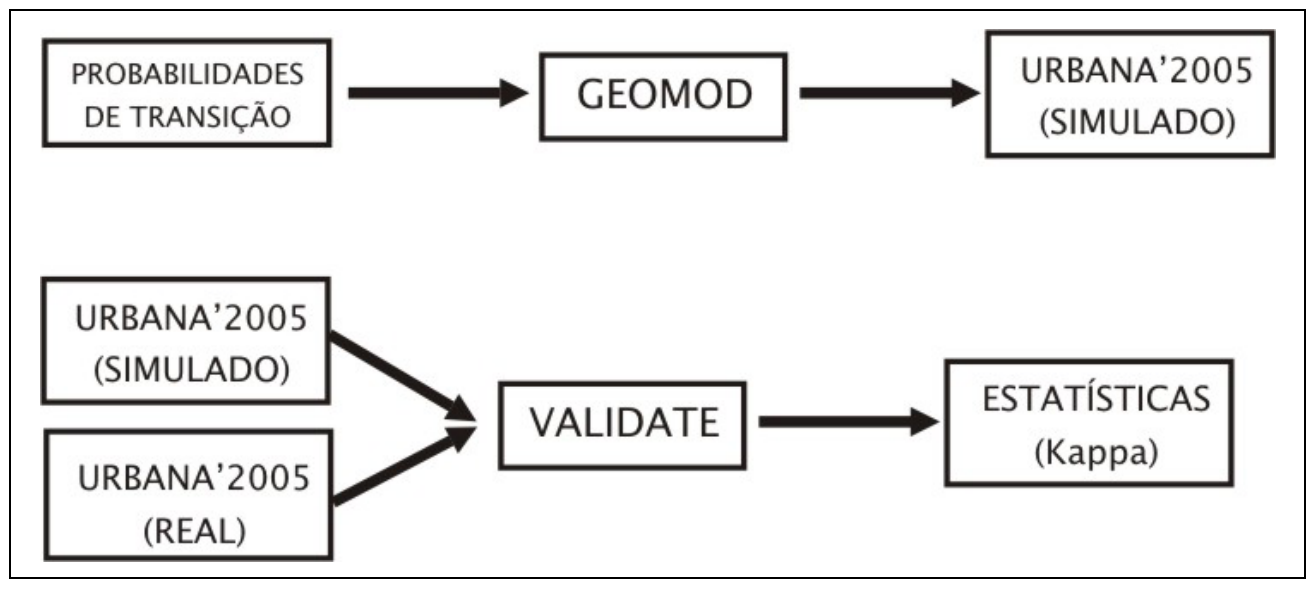

Figura 7. Procedimentos para a validação do modelo

${ }^{15}$ EASTMAN (2003) apresenta as seguintes considerações para a determinação destes coeficientes:

LOGISTICREG utiliza o procedimento de Máxima Verossimilhança para encontrar o melhor conjunto de parâmetros de ajuste, conforme a equação

$$
L=\prod_{i=1}^{N} \mu_{i}^{y_{i}} *\left(1-\mu_{i}\right)^{\left(1-y_{i}\right)}
$$

em que: L é a Verossimilhança; $\mu$ i é o valor previsto para a variável dependente para a amostra $i$; e yé o valor observado para essa amostra.

Sendo assim, o módulo estabelece os valores para pseudo $R^{2}$ pela equação $[1-\log (L) / \log (L 0)]$, em que L0 é o valor para a função de verossimilhança em que todos os coeficientes têm valor zero. Goodness-of-fit (qualidade do ajuste) é calculada baseada na diferença entre os valores observados e previstos para a variável dependente, conforme a equação

$$
\text { Goodness_of } f i t=\sum_{i=1}^{N}\left(y_{i}-\mu_{i}\right)^{2} / \mu_{i} *\left(1-\mu_{i}\right)
$$


No caso do presente trabalho, a comparação entre o mapa simulado e o mapa real foi efetuada aplicando-se o módulo VALIDATE, que verifica a concordância entre dois mapas, tomando-se um deles como referência. Segundo Eastman (2003), a aplicação do módulo permite avaliar a concordância entre os mapas em termos da quantidade e da localização de células por categoria, por meio do estabelecimento de índices de concordância de Kappa gerados pelo VALIDATE.

\subsubsection{Previsão}

Nesta etapa ocorre a aplicação efetiva do modelo para um instante futuro, supondo a manutenção das condições iniciais.

\section{Projeção futura da quantidade de células para o estado 2}

Um dos requisitos do modelo empregado diz respeito ao fornecimento da quantidade de células nos estados 1 e 2 para o instante final de simulação. A despeito das alternativas para a realização desta projeção, e com base em trabalhos semelhantes, essa quantidade foi prevista aplicando-se o método da Cadeia de Markov, utilizando novamente um módulo (MARKOV) disponibilizado pelo software.

Segundo Eastman (2003), este módulo analisa um par de imagens de uso do solo de datas diferentes e retorna como saída uma matriz de probabilidades de transição e uma matriz de áreas de transição, estabelecidas com base no intervalo de tempo entre as duas datas, denominado passo. A matriz de probabilidade de 
transição apresenta a probabilidade de cada categoria de uso do solo mudar para as outras categorias, considerando o passo estabelecido. A matriz de transição de áreas registra o número de pixels que deverão sofrer alteração de uso, para cada categoria de uso do solo, no intervalo de tempo considerado.

Para a efetivação desse procedimento, foram gerados mapas de uso e ocupação do solo para a área de estudo, por meio da classificação supervisionada das imagens de satélite dos anos de 1998 e 2005. Utilizou-se, para tanto, o classificador por máxima verossimilhança (MAXVER), auxiliado por trabalho de campo para a identificação de amostras para 8 categorias de uso do solo consideradas, e para a aferição da classificação (foram visitados 12 pontos por categoria, o que resultou num nível de confiabilidade global de $75 \%$ - equivalente a 72 pontos classificados corretamente).

Reclassificando-se o mapa de uso e ocupação obtido anteriormente, para apenas três categorias de uso e ocupação do solo (AGRÍCOLA, URBANA e VEGETAÇÃO NATIVA), aplicou-se o módulo MARKOV para as alterações observadas entre $t_{1}$ e $t_{2}$.

O período $t_{1}-t_{2}(1998-2005)$ define um "passo" de 7 anos para a Cadeia de Markov. A partir das matrizes de transição geradas pelo módulo MARKOV verifica-se qual é a quantidade de células que serão ocupadas pela categoria URBANA nos dois instantes futuros, que correspondem a um e a dois "passos" a partir de $t_{2}$ (2012 e 2019, respectivamente). 


\section{Geração de cenários}

A fim de gerar informações que fossem utilizadas nas discussões posteriores, em vista do objetivo geral do trabalho, as projeções futuras foram estabelecidas para diferentes cenários, estabelecidos com base em situações hipotéticas de desenvolvimento, que determinariam o "espaço disponível” para a expansão urbana.

Sendo assim, para cada ano projetado (2012 e 2019) foram gerados os seguintes cenários:

Cenário l: a expansão urbana pode se dar sobre toda a área de estudo (não há restrição de qualquer natureza);

Cenário II: a expansão urbana deve ficar restrita aos limites impostos pelo Perímetro Urbano e pela Zona de Expansão Urbana (conforme indicados pelo Plano Diretor);

Cenário III: é o cenário mais restritivo, no qual a expansão urbana deve observar, além dos limites para o Perímetro Urbano e Zona de Expansão, limitações de natureza jurídica (a expansão não pode se dar sobre as Reservas Legais averbadas) e institucional (as áreas dos campi Universitários - UFSCar e USP, e a área de pesquisa da EMBRAPA Pecuária Sudeste encontram-se "indisponíveis" para a ocupação urbana) ou de propriedade privada (empreendimentos privados significativos em extensão e loteamentos de chácaras também são considerados “indisponíveis"). 


\subsubsection{Descrição da metodologia empregada na elaboração do zoneamento ambiental}

A avaliação da aptidão do território com relação à capacidade de suporte apresentada para a ocupação urbana é efetuada, no presente caso, considerandose principalmente os aspectos relacionados aos fatores físicos do território sujeito à urbanização.

Resumidamente, o que se pretende é avaliar qual seria a "reação" do meio frente às solicitações provenientes da implantação e consolidação de novas áreas urbanizadas no município de São Carlos, e dessa forma identificar áreas que apresentem um desempenho otimizado com relação à minimização de riscos ao meio inerentes à urbanização do território, pelo conjunto de características apresentado pelo mesmo.

A figura 8 ilustra a metodologia empregada para a elaboração de um zoneamento ambiental - sobreposição de informações considerando-se critérios específicos para cada fator ambiental, estabelecidos em função das características da atividade avaliada.

A identificação dos fatores ambientais a serem utilizados na elaboração do zoneamento ambiental depende, principalmente, das características básicas do empreendimento a ser avaliado. Além disso, novamente a disponibilidade de informações surge como limitante às avaliações subseqüentes.

No caso da ocupação urbana, com base na literatura e na experiência de profissionais consultados, pode-se citar alguns impactos ao meio físico gerados pela atividade em questão: intensificação de processos erosivos do solo devido à movimentação de terra, poluição e contaminação das águas (superficiais, sub- 
superficiais e subterrânea) por resíduos sólidos e efluentes domésticos e industriais, pressão sobre fragmentos de vegetação nativa, impermeabilização excessiva do solo provocando alterações no escoamento superficial e no ciclo hidrológico, etc.

O Zoneamento Ambiental para Ocupação Urbana, elaborado no presente trabalho, reflete uma avaliação efetuada sobre a capacidade de carga do terreno, associada a avaliações sobre a vulnerabilidade (à infiltração de poluentes) dos recursos hídricos subterrâneos, e sobre o risco potencial para aqüíferos e para os mananciais superficiais.

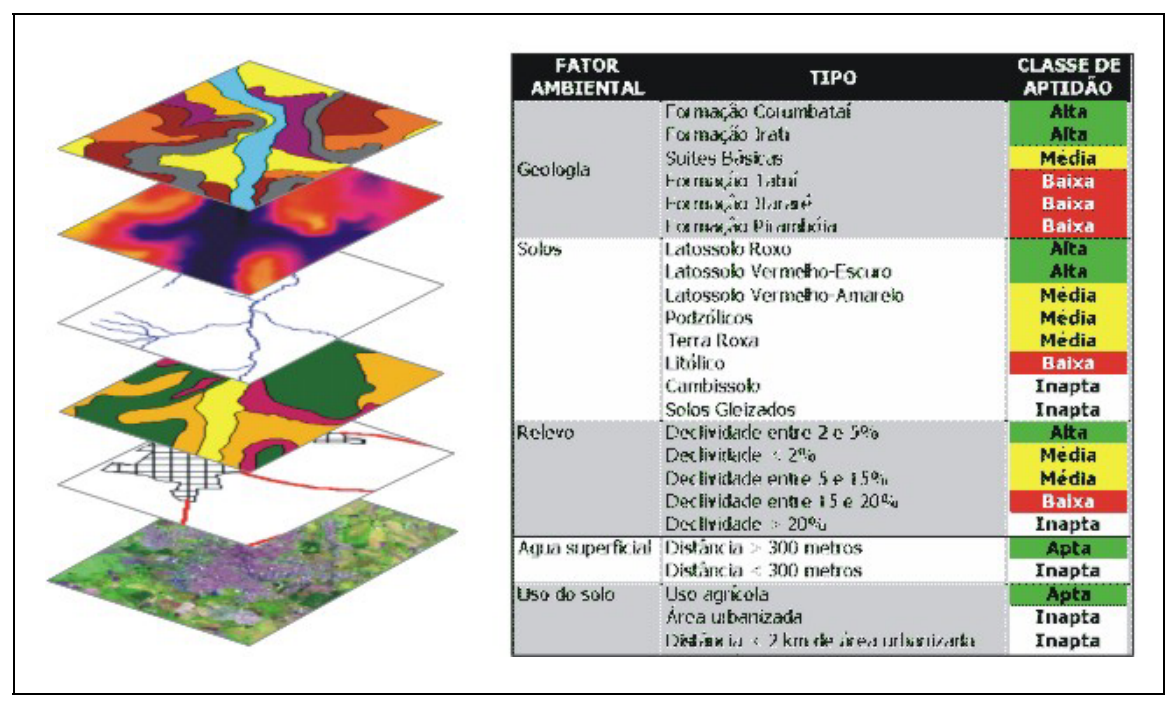

Figura 8. Exemplo de ponderação de fatores ambientais para elaboração de zoneamento ambiental. Montaño et al. (2004) adaptado de Souza et al. (2003)

Evidentemente, trata-se de uma proposta metodológica que reflete, dentre outras questões, uma preocupação com a prevenção de impactos ambientais significativos (minimizando a probabilidade da sua ocorrência). Não existe, como não poderia deixar de ser, a pretensão de se apresentar uma proposta definitiva em termos metodológicos para o zoneamento ambiental. 


\subsubsection{Avaliação da capacidade de carga do terreno}

A capacidade de uso do solo ${ }^{16}$ para fins agrícolas foi avaliada para o município de São Carlos por Montaño, Bertolani e Souza (2004). Os autores propõem que as informações contidas no mapa de Capacidade de Uso do Solo podem ser utilizadas para o planejamento da expansão urbana, uma vez que a sua legenda pode ser interpretada como refletindo a intensidade com que um determinado tipo de solo pode ser trabalhado mecanicamente, em função da declividade do terreno.

A matriz utilizada para a elaboração do mapa de Capacidade de Uso do Solo é apresentada na tabela 1 .

Tabela 1 - Critérios para a determinação da Capacidade de Uso do Solo, segundo Montaño, Bertolani e Souza (2004). Nomenclatura dos solos que ocorrem no município de São Carlos atualizadas conforme o Sistema Brasileiro de Classificação de Solos (EMBRAPA, 1999).

\begin{tabular}{|c|c|c|c|c|c|c|c|}
\hline & & \multicolumn{6}{|c|}{ Intervalos de Declividade } \\
\hline & & 0 a $3 \%$ & 3 a $6 \%$ & 6 a $12 \%$ & 12 a $20 \%$ & 20 a $40 \%$ & $>40 \%$ \\
\hline \multirow{10}{*}{ 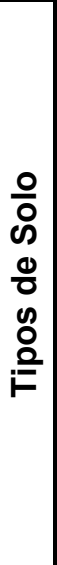 } & Latossolo eutroférrico (LRe) & Classe I & Classe I & Classe I & Classe IV & Classe VII & Classe VIII \\
\hline & Latossolo distroférrico (LRd) & Classe II & Classe II & Classe II & Classe IV & Classe VII & Classe VIII \\
\hline & Latossolo Vermelho (LE) & Classe III & Classe III & Classe III & Classe IV & Classe VII & Classe VIII \\
\hline & Latossolo Vermelho-Amarelo (LV) & Classe III & Classe III & Classe III & Classe IV & Classe VII & Classe VIII \\
\hline & Argissolo Vermelho-Amarelo (PV) & Classe II & Classe II & Classe III & Classe IV & Classe VI & Classe VII \\
\hline & $\begin{array}{l}\text { Argissolo Vermelho-Amarelo } \\
\text { (abrúptico) (PV5) }\end{array}$ & Classe III & Classe III & Classe IV & Classe VI & Classe VII & Classe VIII \\
\hline & Nitossolo (TE) & Classe II & Classe II & Classe III & Classe IV & Classe VI & Classe VIII \\
\hline & Gleissolo (Hi) & Classe V & Classe V & Classe VI & Classe VI & Classe VI & Classe VIII \\
\hline & Neossolo Litólico (Li) & Classe VII & Classe VII & Classe VII & Classe VII & Classe VII & Classe VIII \\
\hline & Neossolo Quartzarênico (AQ) & Classe IV & Classe IV & Classe VI & Classe VII & Classe VII & Classe VIII \\
\hline
\end{tabular}

\footnotetext{
${ }^{16}$ O sistema de capacidade de uso do solo, segundo Lepsch (2002), se baseia na avaliação das limitações permanentes das terras e é voltado para a determinação de restrições à utilização das mesmas, que estão diretamente relacionadas à sua intensidade de uso. Por intensidade de uso, entende-se a maior ou menor mobilização imposta ao solo, expondo-o a certo risco de erosão e/ou perda da produtividade.
} 
A interpretação do mapa de Capacidade de Uso do Solo indica que a atividade agrícola mecanizada (e intensiva) apresenta condições de ser realizada, com um determinado grau de atenção relacionado a práticas de cultivo, nas Classes de I a IV (ou Classe V, considerando a possibilidade de exploração de Gleissolos hidromórficos).

Admitindo que a mesma interpretação seja aplicável na avaliação da ocupação urbana, nesse caso excluindo-se a Classe $\mathrm{V}$ por ser vinculada a solos hidromórfico, pode-se entender que o mapa indica a aptidão do solo em suportar os esforços mecânicos decorrentes da implantação do empreendimento "ocupação urbana" (considerando que nesta etapa, ocorre a concentração das solicitações mecânicas sobre o solo, bem como a permanência de longos períodos em que o mesmo permanece exposto). Nesse caso, a ponderação efetuada sobre o mapa de Capacidade de Uso do Solo segue a tabela 2.

Tabela 2 - Classes de aptidão para a ocupação urbana adotadas em função da Capacidade de Uso do Solo

\begin{tabular}{|c|c|}
\hline Classe de aptidão & Capacidade de Uso do Solo \\
\hline SEM APTIDÃO & Classes V a VIII \\
\hline BAIXA & Classe IV \\
\hline MÉDIA & Classe III \\
\hline ALTA & Classes I e II \\
\hline
\end{tabular}

\subsubsection{Vulnerabilidade dos recursos hídricos subterrâneos}

Montaño (2002) apresenta o mapa de "Risco de contaminação de águas subterrâneas" elaborado para o município de São Carlos, a partir de metodologia proposta por Grecchi (1998), segundo a qual o risco de contaminação de águas 
subterrâneas pode ser verificado pela sobreposição dos fatores declividade, permeabilidade e profundidade do solo, densidade hídrica (número de canais de $1^{\text {a }}$. ordem por $\mathrm{km}^{2}$ ) e formações geológicas.

No presente caso, propõe-se uma adaptação desta metodologia a fim de avaliar a contribuição da camada de solo no sentido de dificultar a infiltração de eventuais poluentes. Nesse sentido, a vulnerabilidade dos recursos hídricos subterrâneos é avaliada com relação à possibilidade do poluente atingir a formação geológica (que pode ou não estar associada a um sistema aqüífero), e descrita pela associação dos fatores declividade do terreno, profundidade e permeabilidade dos solos. As tabelas 3 a 5 indicam a ponderação efetuada sobre cada um destes fatores, conforme Montaño (2002).

Tabela 3 - Classes de vulnerabilidade adotadas em função de intervalos de declividade

\begin{tabular}{|c|c|}
\hline $\begin{array}{c}\text { Classe de } \\
\text { vulnerabilidade }\end{array}$ & $\begin{array}{c}\text { Intervalos de } \\
\text { declividade }\end{array}$ \\
\hline BAIXA & acima de $15 \%$ \\
\hline MÉDIA & de 5 a $15 \%$ \\
\hline ALTA & de 0 a $5 \%$ \\
\hline
\end{tabular}

Tabela 4 - Classes de vulnerabilidade adotadas em função da profundidade do solo

\begin{tabular}{|c|c|c|}
\hline Profundidade & $\begin{array}{c}\text { Classe de } \\
\text { vulnerabilidade }\end{array}$ & Tipo de solo \\
\hline Muito profundo & BAIXA & $\begin{array}{c}\text { LRd, LRe, } \\
\text { LE, LV }\end{array}$ \\
\hline $\begin{array}{c}\text { Moderadamente } \\
\text { profundo a profundo }\end{array}$ & MÉDIA & $\mathrm{AQ}, \mathrm{TE}, \mathrm{PV}$ \\
\hline Rasos & $\mathrm{ALTA}$ & $\mathrm{Li}, \mathrm{Hi}$ \\
\hline
\end{tabular}


Tabela 5 - Classes de vulnerabilidade adotadas em função da permeabilidade do solo

\begin{tabular}{|c|c|c|}
\hline Permeabilidade & $\begin{array}{c}\text { Classe de } \\
\text { vulnerabilidade }\end{array}$ & Tipo de solo \\
\hline BAIXA & BAIXA & LRe, LRd, TE \\
\hline MÉDIA & MÉDIA & LV, LE, PV \\
\hline ALTA & ALTA & AQ, Li, Hi \\
\hline
\end{tabular}

Os três fatores considerados, previamente escalonados ${ }^{17}$ para o intervalo de 0 a 255 (utilizando o módulo $F U Z Z Y^{18}$ ), foram integrados por meio de uma combinação linear ponderada dos fatores atribuindo-se um peso superior para a permeabilidade do solo em relação aos outros dois fatores $(0,3$ para declividade e profundidade, e 0,4 para a permeabilidade), admitindo ser a permeabilidade o elemento que mais favorece o processo de infiltração no solo.

O resultado desse procedimento é um mapa que apresenta valores escalonados entre 0 e 255, no sentido da maior para a menor vulnerabilidade. Esses valores foram divididos em intervalos iguais $(0-84,84-168,168-255)$, que definiram as categorias de vulnerabilidade BAIXA, MÉDIA e ALTA.

O mapa resultante foi reclassificado de modo a indicar a aptidão para a ocupação urbana, em função da vulnerabilidade das águas subterrâneas, conforme a tabela 6.

\footnotetext{
17 Trata-se de uma exigência para a aplicação do módulo MCE (Multi-Criterial Evaluation) do IDRISI para aplicação da Análise Multi-Criterial.

$18 \mathrm{O}$ módulo FUZZY permite efetuar o escalonamento de valores para intervalos de números reais compreendidos entre 0 e 1 , ou números inteiros entre 0 e 255 . Avalia a possibilidade de cada pixel da imagem pertencer a um conjunto difuso (fuzzy), descrito por uma função pré-estabelecida (linear, sigmoidal ou curva-J) por meio dos pontos de inflexão fornecidos. No presente caso, foi empregada uma função de ajuste linear.
} 
Tabela 6 - Classes de aptidão para a ocupação urbana em função da vulnerabilidade dos recursos hídricos subterrâneos

\begin{tabular}{|c|c|}
\hline $\begin{array}{c}\text { Classe de } \\
\text { vulnerabilidade }\end{array}$ & $\begin{array}{c}\text { Classe de aptidão } \mathrm{p} / \\
\text { ocupação urbana }\end{array}$ \\
\hline ALTA & BAIXA \\
\hline MÉDIA & MÉDIA \\
\hline BAIXA & ALTA \\
\hline
\end{tabular}

\subsubsection{Ponderação sobre os fatores}

Os mapas para Classe de Capacidade de Uso e Vulnerabilidade dos Recursos Hídricos Subterrâneos foram sobrepostos e reclassificados de acordo com a tabela 7, gerando o mapa denominado "Aptidão do Terreno". Esse mapa permite avaliar a capacidade do terreno em suportar (fisicamente) a implantação do empreendimento, ao mesmo tempo em que é avaliada a proteção aos recursos hídricos subterrâneos, em função das condições de solo e declividade.

Tabela 7 - Ponderação efetuada para a obtenção do mapa "Aptidão do Terreno"

\begin{tabular}{|c|c|c|c|c|}
\hline \multirow{2}{*}{\multicolumn{2}{|c|}{ APTIDÃO TERRENO }} & \multicolumn{3}{|c|}{ Aptidão Vulnerabilidade } \\
\hline & & baixa & média & alta \\
\hline \multirow{4}{*}{ 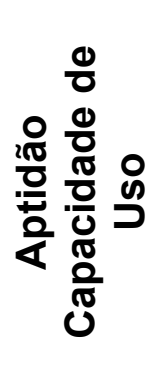 } & s/ aptidão & s/ aptidão & s/ aptidão & s/ aptidão \\
\hline & baixa & muito baixa & baixa & baixa \\
\hline & média & baixa & média & média \\
\hline & alta & média & média-alta & alta \\
\hline
\end{tabular}

De modo a considerar a necessidade de minimizar o risco de contaminação aos recursos hídricos subterrâneos, e considerando a presença de sistemas aqüíferos 
normalmente associados às formações geológicas Botucatu e Pirambóia, bem como da fragilidade associada aos depósitos aluviais, a sobreposição entre o mapa "Aptidão do terreno" e o mapa de Geologia para a área de estudo foi reclassificada conforme a tabela 8, a seguir, o que resultou no mapa denominado "Aptidão Geologia”.

Tabela 8 - Ponderação efetuada para a obtenção do mapa "Aptidão Geologia"

\begin{tabular}{|c|c|c|c|c|c|c|c|}
\hline \multirow{2}{*}{\multicolumn{2}{|c|}{ APTIDÃO GEOLOGIA }} & \multicolumn{6}{|c|}{ Aptidão Terreno } \\
\hline & & \multirow{2}{*}{$\begin{array}{c}\begin{array}{c}\text { sem } \\
\text { aptidão }\end{array} \\
\begin{array}{c}\text { sem } \\
\text { aptidão }\end{array}\end{array}$} & \multirow{2}{*}{$\begin{array}{c}\begin{array}{c}\text { muito } \\
\text { baixa }\end{array} \\
\text { sem } \\
\text { aptidão }\end{array}$} & \multirow{2}{*}{$\begin{array}{c}\text { baixa } \\
\text { sem } \\
\text { aptidão }\end{array}$} & \multirow{2}{*}{$\begin{array}{l}\text { média } \\
\text { muito } \\
\text { baixa }\end{array}$} & \multirow{2}{*}{$\begin{array}{l}\begin{array}{c}\text { média- } \\
\text { alta }\end{array} \\
\text { média }\end{array}$} & \multirow{2}{*}{$\frac{\text { alta }}{\text { média }}$} \\
\hline న్ర్లు & $\begin{array}{c}\text { Botucatu } \\
\text { Pirambóia } \\
\text { Depósitos aluviais }\end{array}$ & & & & & & \\
\hline 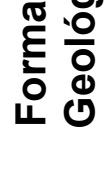 & $\begin{array}{c}\text { Serra Geral } \\
\text { Depósitos de } \\
\text { Cimeira } \\
\text { Magmatitos básicos }\end{array}$ & $\begin{array}{c}\text { sem } \\
\text { aptidão }\end{array}$ & $\begin{array}{l}\text { muito } \\
\text { baixa }\end{array}$ & baixa & média & $\begin{array}{c}\text { média- } \\
\text { alta }\end{array}$ & alta \\
\hline
\end{tabular}

A avaliação efetuada inclui, em paralelo com a determinação do mapa "Aptidão Geologia", uma etapa que denota uma preocupação com a preservação de mananciais superficiais de abastecimento. A partir da delimitação das bacias de captação superficial que atendem o município atualmente, sobrepondo-as ao mapa "Aptidão do Terreno" num procedimento semelhante ao utilizado para a geração do mapa anterior, e aplicando-se a ponderação apresentada na tabela 9 , obtém-se o mapa denominado "Aptidão Mananciais".

Tabela 9 - Ponderação efetuada para a obtenção do mapa "Aptidão Mananciais"

\begin{tabular}{|c|c|c|c|c|c|c|}
\hline \multirow{2}{*}{ APTIDÃO MANANCIAIS } & \multicolumn{7}{|c|}{ Aptidão Terreno } \\
\cline { 2 - 7 } & $\begin{array}{c}\text { sem } \\
\text { aptidão }\end{array}$ & $\begin{array}{c}\text { muito } \\
\text { baixa }\end{array}$ & baixa & média & $\begin{array}{c}\text { média- } \\
\text { alta }\end{array}$ & alta \\
\hline $\begin{array}{c}\text { BACIAS DE CAPTAÇÃo } \\
\text { SUPERFICIAL }\end{array}$ & $\begin{array}{c}\text { sem } \\
\text { aptidão }\end{array}$ & $\begin{array}{c}\text { sem } \\
\text { aptidão }\end{array}$ & $\begin{array}{c}\text { sem } \\
\text { aptidão }\end{array}$ & baixa & baixa & baixa \\
\hline
\end{tabular}


Ao final, a aptidão para ocupação urbana é obtida pela sobreposição dos mapas "Aptidão Geologia" e "Aptidão Mananciais", valendo-se da ponderação apresentados na tabela 10. Vale ressaltar que o mapa "Aptidão Mananciais" só é válido para as bacias de captação superficial que servem atualmente ao Município. Nas demais áreas, mantém-se a classe de aptidão do mapa “Aptidão Geologia".

Tabela 10 - Ponderação efetuada para a obtenção do mapa "Aptidão para ocupação urbana"

\begin{tabular}{|c|c|c|c|c|c|c|c|}
\hline \multirow{2}{*}{\multicolumn{2}{|c|}{$\begin{array}{c}\text { APTIDÃO PARA } \\
\text { OCUPAÇÃO URBANA }\end{array}$}} & \multicolumn{6}{|c|}{ Aptidão Geologia } \\
\hline & & \multirow{2}{*}{$\begin{array}{c}\begin{array}{c}\text { sem } \\
\text { aptidão }\end{array} \\
\begin{array}{c}\text { sem } \\
\text { aptidão }\end{array}\end{array}$} & \multirow{2}{*}{$\begin{array}{c}\begin{array}{c}\text { muito } \\
\text { baixa }\end{array} \\
\text { sem } \\
\text { aptidão }\end{array}$} & \multirow{2}{*}{$\begin{array}{c}\text { baixa } \\
\text { sem } \\
\text { aptidão }\end{array}$} & \multirow{2}{*}{$\begin{array}{l}\text { média } \\
\text { sem } \\
\text { aptidão }\end{array}$} & \multirow{2}{*}{$\begin{array}{c}\begin{array}{c}\text { média- } \\
\text { alta }\end{array} \\
\text { sem } \\
\text { aptidão }\end{array}$} & \multirow{2}{*}{ 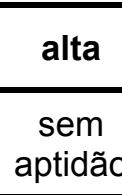 } \\
\hline 을 & sem aptidão & & & & & & \\
\hline 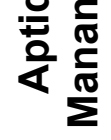 & baixa & $\begin{array}{c}\text { sem } \\
\text { aptidão }\end{array}$ & $\begin{array}{l}\text { sem } \\
\text { aptidão }\end{array}$ & $\begin{array}{l}\text { muito } \\
\text { baixa }\end{array}$ & baixa & baixa & baixa \\
\hline
\end{tabular}




\section{RESULTADOS E DISCUSSÃO}

Os resultados obtidos com a aplicação da metodologia descrita no capítulo anterior são apresentados a seguir, de forma sistematizada, organizados conforme a seqüência em que foram apresentados. Discussões de natureza específica são apresentadas no decorrer da apresentação dos resultados. O capítulo encerra com discussões de ordem geral, voltadas para a aplicação conjunta da modelagem para a projeção das modificações no uso e ocupação do solo do território e outros instrumentos de gestão ambiental.

\subsection{Modelagem e projeção da expansão urbana}

\subsubsection{Calibração}

5.1.1.1. Verificação do relacionamento das variáveis independentes com o fenômeno

Os histogramas para a verificação do relacionamento das variáveis elencadas com a expansão urbana verificada no período 1998-2005 são apresentados a seguir, figuras 9 e 10. 

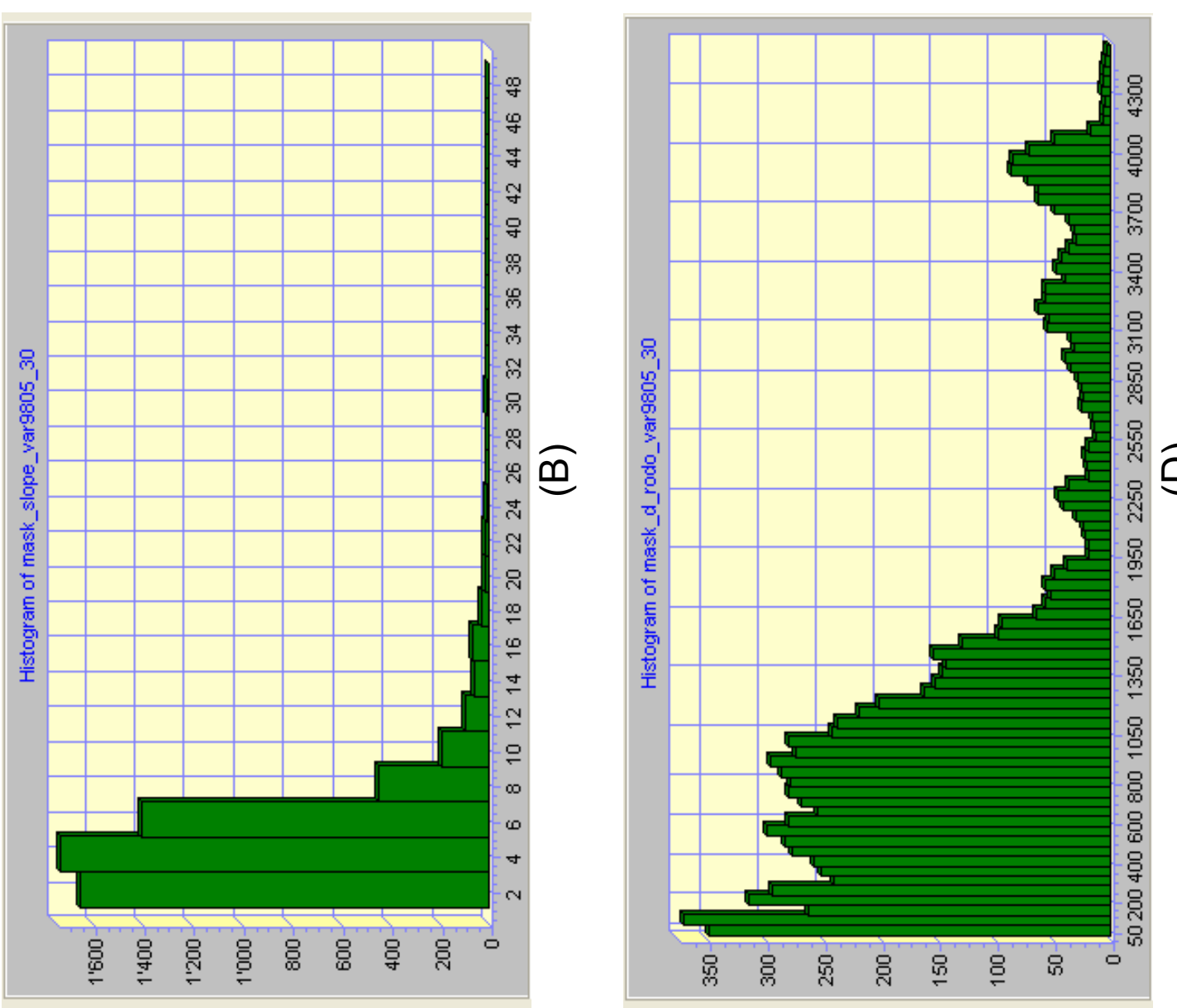

$\frac{\varepsilon}{\sigma}$
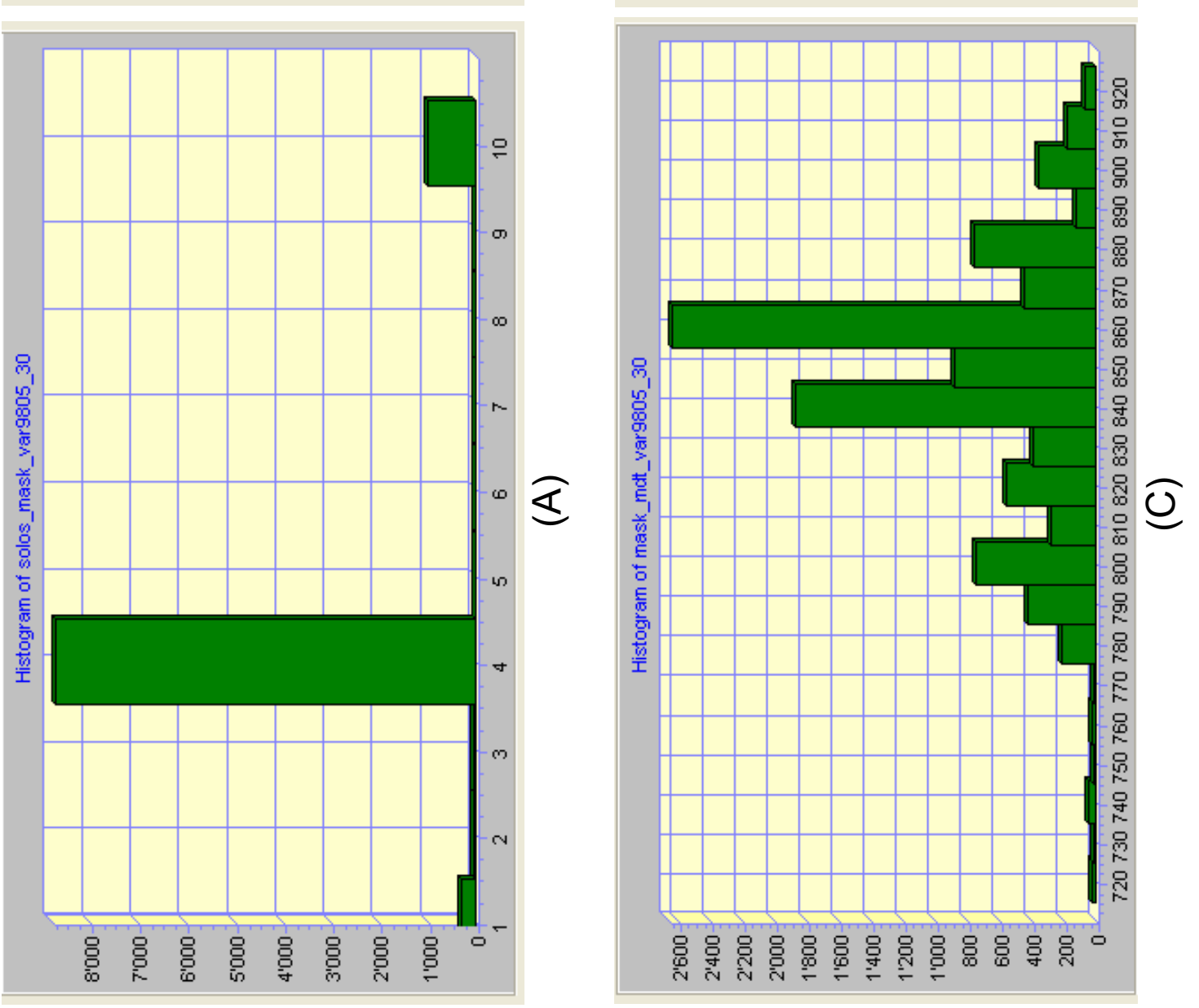

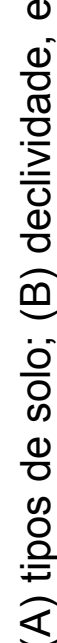

$\leq$

ํํㅇํㅇ

ᄂ

ํํㅇ

ó

ᄋ요

응 동

은

¿

원

(2) $\frac{0}{x}$

तิ

옥.

응

๙

도

ปั)

- $\sigma \frac{0}{\pi}$

क क

里

ฮิ

o

के ?

ब

ठํ

क ह

긍

0 궁

$\frac{0}{\frac{7}{\sigma}}$

웡

ह $\frac{\xi}{0}$

कi

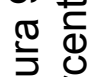
은 응 

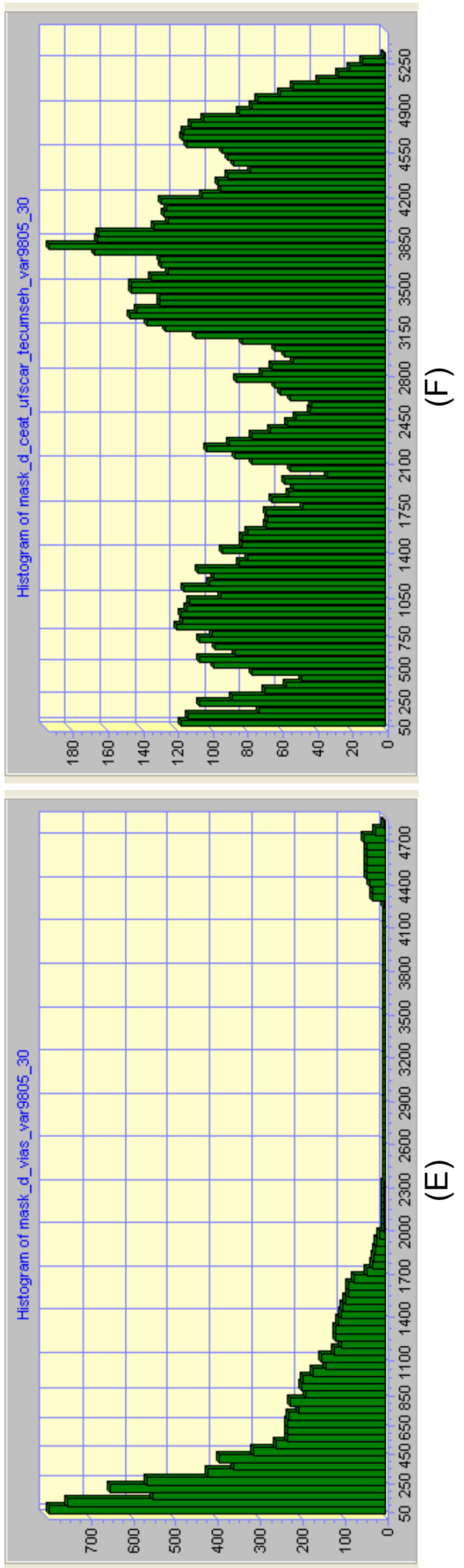

10

요

क -

ปั $\frac{\varepsilon}{\Phi}$

(1)

क)

髚

ब

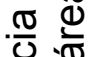

扥

응

근

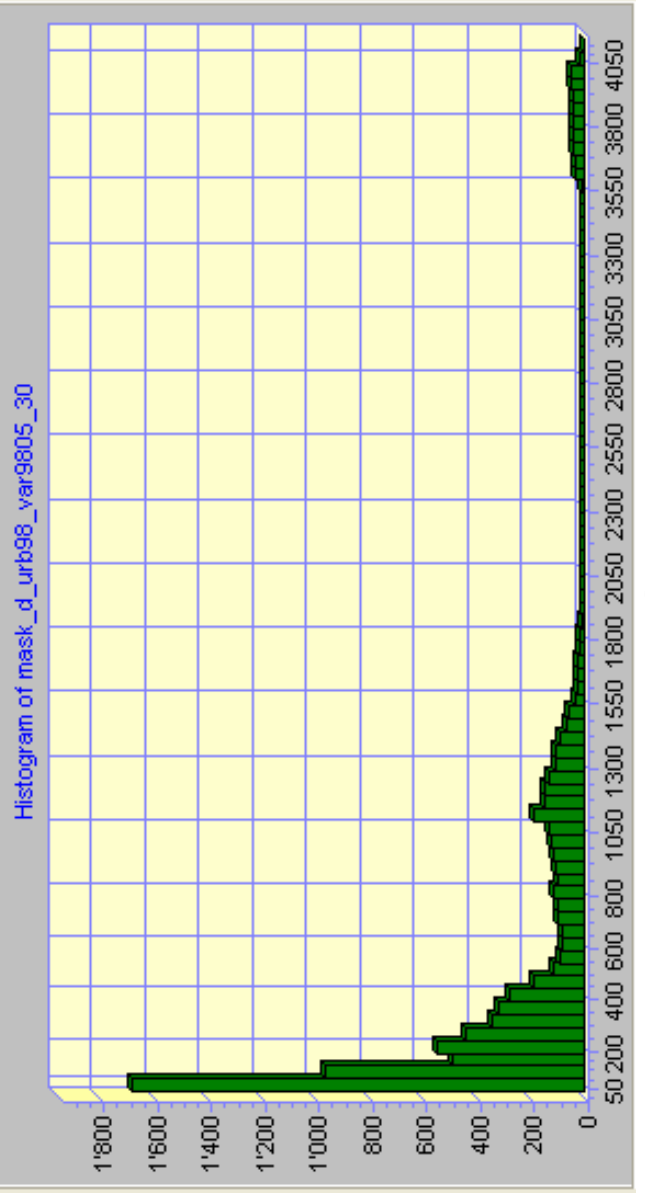

Шి.

‥

은

10

으

\% 1

๑..

is

응 잉

产 苋

으

오 용

(1) $\frac{0}{\frac{1}{2}}$

(

은

잉

2

क

정

$-\pi$

\& ह

듬 $\frac{0}{0}$

동

응

능

क)

๑) ह

잉

(亠)

ह

으 토

진 엉

므 뭉 
Após a análise dos histogramas apresentados, foram desconsideradas como variáveis "explicativas" do fenômeno da expansão urbana para o período considerado as variáveis altitude (C) e os empreendimentos "indutores" (F) por considerar que não apresentam uma relação direta com a expansão urbana, conforme segue:

Altitude (C) - descartada em função da grande variabilidade do histograma observado, indicando não haver relação direta entre a expansão urbana e a cota altimétrica. Pela observação do histograma, constata-se uma predominância da ocupação de locais situados entre $840 / 870$ metros, mas muito provavelmente tratase de uma situação conjuntural - na medida em que a expansão se der por áreas de cotas variadas, poderá haver predominância por outros intervalos de cota. No caso de São Carlos, não há uma relação direta entre a ocupação urbana e a cota altimétrica, como ocorre em áreas tradicionalmente sujeitas à inundação (por exemplo, Joinville - SC e Itajubá - MG), em que o movimento para a ocupação de novas áreas se concentra nas cotas mais elevadas.

Distância a empreendimentos "indutores" $(F)$ - percebe-se novamente uma grande variabilidade encontrada no histograma. Imagina-se que um empreendimento desse tipo possa exercer uma "atração" localizada, restrita a certo raio ao seu redor (concentrando estudantes ou trabalhadores que procurassem morar perto da Universidade ou indústria, por exemplo). Pelo histograma apresentado não é possível separar a influência de tais empreendimentos para a expansão urbana, ainda que, definitivamente, tenham sua parcela de contribuição para o crescimento da cidade.

As demais variáveis apresentam uma relação mais perceptível, pelos histogramas apresentados, com a expansão urbana para o período em questão. 
Portanto, a regressão logística efetuada considera as variáveis: tipos de solo (A), declividade do terreno (B), distância a rodovias (D), distância a acessos rodoviários ou vias de ligação em 1998 (E), e distância à área urbanizada em 1998 (G).

5.1.1.2. Desempenho das combinações entre as variáveis independentes para a geração do mapa de probabilidades de transição

Os resultados da aplicação do módulo LOGISTICREG, para 31 combinações entre as variáveis empregadas na regressão logística, são apresentados na tabela 11. O desempenho da regressão é verificado pelos maiores valores para Pseudo $R^{2}$ e ROC, e para os menores valores do indicador de qualidade do ajuste.

A avaliação dos indicadores de desempenho permite concluir quais equações para a probabilidade de transição entre os estados 1 e 2 (NÃO-URBANO e URBANO), obtidas da regressão logística, apresentam um melhor ajuste com o fenômeno da expansão urbana no período 1998-2005. Verifica-se, nesse caso, que a equação obtida combinando-se tipos de solo, declividade, distância a rodovias e distância à área urbanizada em $1998(A+B+D+G)$ apresenta os melhores resultados para Pseudo $\mathrm{R}^{2}$ e ROC, e a equação resultante da combinação de tipos de solo, declividade, distância a rodovias e distância a vias de acesso ou vias de ligação $(A+B+D+E)$ apresenta o melhor resultado para o indicador de qualidade do ajuste (goodness of fit). 
Tabela 11 - Indicadores de desempenho para a regressão logística, em função da combinação entre as variáveis empregadas na regressão, e indicação das combinações de melhor desempenho.

\begin{tabular}{|c|c|c|c|}
\hline $\begin{array}{c}\text { Variáveis } \mathrm{p} / \\
\text { regressão }\end{array}$ & Pseudo $\mathbf{R}^{2}$ & ROC & $\begin{array}{l}\text { Qualidade do ajuste } \\
\text { (Goodness of fit) }\end{array}$ \\
\hline$A$ & 0.1193 & 0.7708 & 82291.6172 \\
\hline$A+B$ & 0.1344 & 0.8085 & 94228.1172 \\
\hline$A+B+D$ & 0.1715 & 0.8495 & 106853.6016 \\
\hline$A+B+D+E$ & 0.3408 & 0.9341 & 52445.9922 \\
\hline$A+B+D+E+G$ & 0.3733 & 0.9447 & 157793.0938 \\
\hline$A+B+D+G$ & 0.3818 & 0.9469 & 117789.125 \\
\hline$A+B+E$ & 0.3342 & 0.9325 & 88911.6641 \\
\hline$A+B+E+G$ & 0.3775 & 0.9458 & 167276.9844 \\
\hline$A+B+G$ & 0.3697 & 0.9436 & 89909.4141 \\
\hline$A+D$ & 0.16 & 0.8374 & 92394.5078 \\
\hline$A+D+E$ & 0.3281 & 0.9302 & 68631.9141 \\
\hline$A+D+E+G$ & 0.3705 & 0.9446 & 189771.7188 \\
\hline$A+D+G$ & 0.3632 & 0.9424 & 102530.0391 \\
\hline$A+E$ & 0.3186 & 0.9281 & 117816.7422 \\
\hline$A+E+G$ & 0.3715 & 0.9454 & 210739.2344 \\
\hline$A+G$ & 0.3653 & 0.9434 & 101667.5859 \\
\hline $\mathrm{B}$ & 0.0315 & 0.6502 & 76780.4844 \\
\hline$B+D$ & 0.0948 & 0.7687 & 71919.8984 \\
\hline$B+D+E$ & 0.304 & 0.9214 & 88305.1094 \\
\hline$B+D+E+G$ & 0.362 & 0.9425 & 472229.2188 \\
\hline$B+D+G$ & 0.3429 & 0.9361 & 165207.375 \\
\hline$B+E$ & 0.3029 & 0.9223 & 140184.5469 \\
\hline$B+E+G$ & 0.3564 & 0.9395 & 373874.125 \\
\hline$B+G$ & 0.3438 & 0.9365 & 150953.9219 \\
\hline $\mathrm{D}$ & 0.0732 & 0.7323 & 69861.2422 \\
\hline $\mathrm{D}+\mathrm{E}$ & 0.3032 & 0.9223 & 114860.9063 \\
\hline$D+E+G$ & 0.3479 & 0.9401 & 634106.3125 \\
\hline$D+G$ & 0.3183 & 0.9305 & 170234.625 \\
\hline$E$ & 0.2871 & 0.9169 & 220210.2031 \\
\hline$E+G$ & 0.3423 & 0.9382 & 561831.5 \\
\hline$G$ & 0.3292 & 0.9346 & 203611.1563 \\
\hline
\end{tabular}

Estas equações são apresentadas na figura 11 na forma de mapas de probabilidades de transição. 

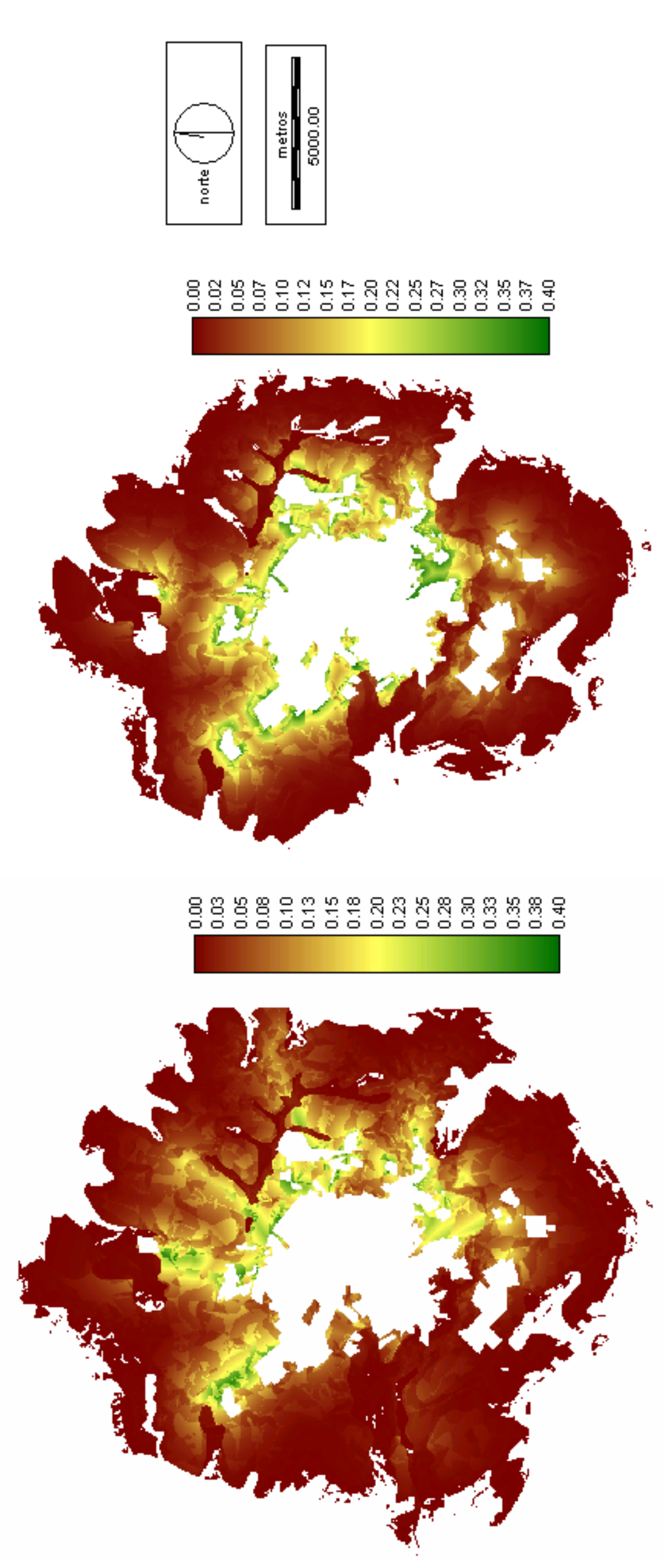

뜯 응 융

월 몬

此市

है응 잉

D $0 \frac{\pi}{1} \frac{\pi}{0}$

응 응 슨

흘 징 율

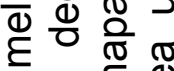
๑ 응 ह (1) ๑

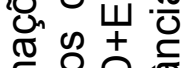
을 을

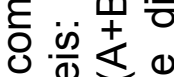

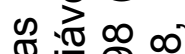
( 뜌 인

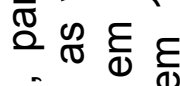
용요 < 垴 品 200

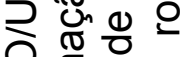
은 这卷 है है $\frac{\pi}{>} \cdot \frac{\pi}{0}$ 茫 잉응 这응 은 윤 $\frac{\pi}{5}$ 응 인

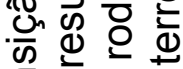
뚜 잉 응

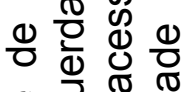
응 궁 $\frac{\pi}{0}$ $\pi$ 음

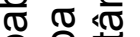
을 을 흥 응 잉 is

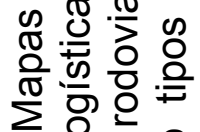
$\therefore$ 정

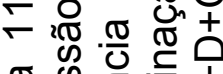
땡

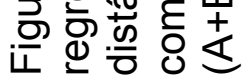




\subsubsection{Validação}

Alimentando o modelo com os mapas de probabilidade de transição selecionados na etapa anterior, aplicando-se o módulo GEOMOD para o período 1998-2005, obtêm-se os resultados conforme a figura 12.
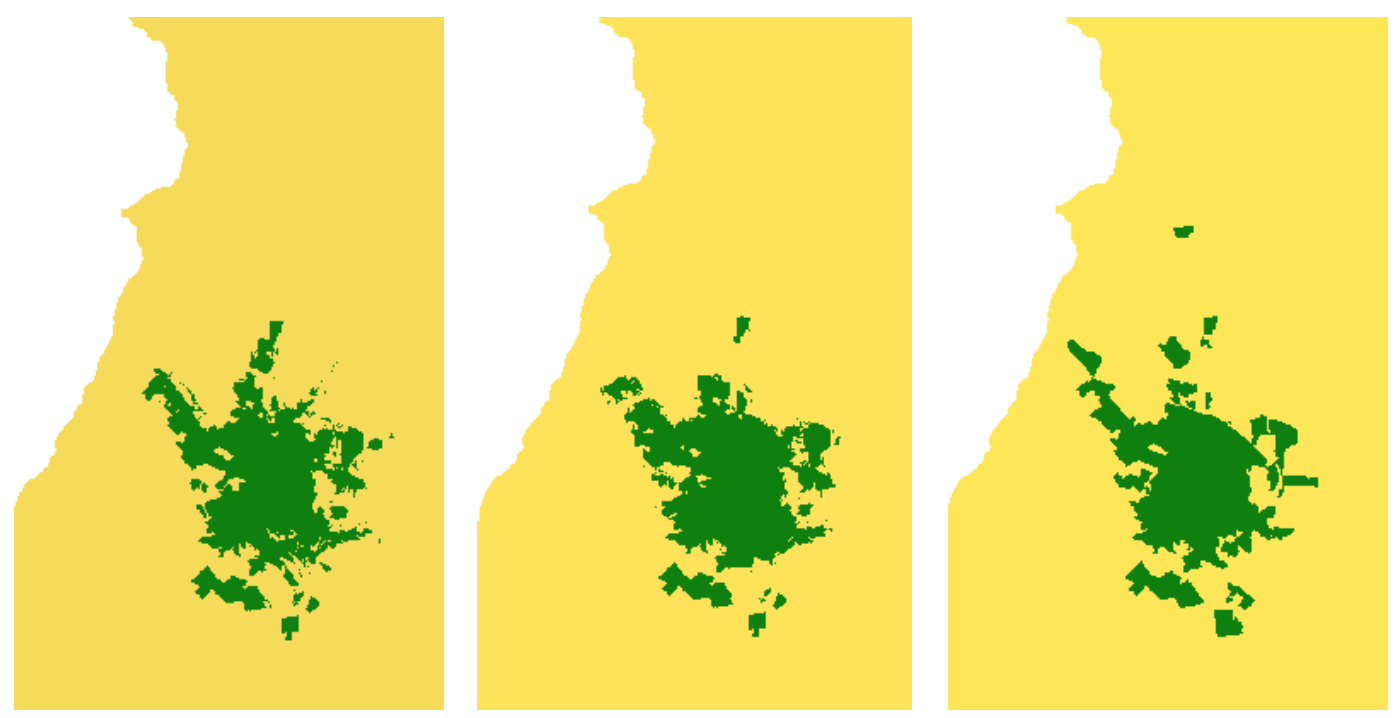

Figura 12. Área urbana prevista pelo modelo GEOMOD para o ano de 2005 a partir do mapa de probabilidades de transição gerado para as combinações $A+B+D+E$ (esq.) e $A+B+D+G$ (centro). À direita, área urbana real para o ano 2005.

A validação do modelo é feita a partir da análise dos indicadores de concordância estabelecidos pela comparação dos mapas previstos pelo modelo com mapa real, para o ano de 2005. Nesse sentido, a aplicação do módulo VALIDATE gera os resultados apresentados a seguir (tabela 12).

Tabela 12 - Índice de Concordância de Kappa para os mapas previstos para o ano de 2005, em comparação com o mapa real.

\begin{tabular}{|c|c|}
\hline $\begin{array}{c}\text { Variáveis utilizadas pelo mapa de } \\
\text { probabilidades de transição }\end{array}$ & $\begin{array}{c}\text { índice de Concordância } \\
\text { de Kappa }\end{array}$ \\
\hline$A+B+D+E$ & 0.8366 \\
\hline$A+B+D+G$ & 0.8524 \\
\hline
\end{tabular}


Os índices obtidos indicam uma concordância entre os mapas previstos e a realidade, compatível à concordância obtida por trabalhos semelhantes, citados no ítem 3.4 da revisão bibliográfica. Ainda que os resultados quantitativos devam ser observados com critério (em virtude da tendência de se obter valores elevados para os índices de concordância, ao se trabalhar com imagens booleanas), destaca-se o fato de que o módulo VALIDATE é empregado aqui com o intuito de se estabelecer um comparativo entre as concordâncias obtidas para as diferentes simulações realizadas, indicando qual delas apresenta - estatisticamente - o melhor comportamento em comparação com a realidade.

Para a projeção futura da ocupação urbana, o modelo GEOMOD será alimentado com o mapa de probabilidades de transição de melhor desempenho, ou seja, pela combinação das variáveis tipos de solo, declividade, distância a rodovias e distância à área urbana no tempo inicial $(A+B+D+G)$.

\subsubsection{Previsão}

\subsubsection{Projeção futura da quantidade de células para o estado 2}

O resultado da classificação das imagens de satélite, e os mapas de uso e ocupação para as categorias AGRÍCOLA, VEGETAÇÃO NATIVA e URBANA são apresentados na figuras 13 e 14. A tabela 13 mostra a distribuição e as alterações no uso e ocupação do solo na área de estudo, para o período de 1998 a 2005. Os valores encontrados nesta tabela servem de base para a quantificação da expansão urbana pelo método da Cadeia de Markov, por meio do módulo MARKOV disponível no software utilizado. 
Tabela 13 - Alterações no uso e ocupação do solo no período 1998-2005, para as categorias AGRÍCOLA, VEGETAÇÃO NATIVA e URBANA (em hectares).

\begin{tabular}{|c|c|c|c|}
\hline & AGR & VEG & URB \\
\hline $\mathbf{1 9 9 8}$ & 34051.68 & 13049.37 & 3587.11 \\
\hline $\mathbf{2 0 0 5}$ & 35324.23 & 10827.76 & 4550.62 \\
\hline
\end{tabular}

Os resultados da aplicação do módulo MARKOV, a partir das alterações observadas no período 1998-2005, para a quantificação futura das três categorias de uso e ocupação do solo são apresentados na tabela 14.

Tabela 14 - Uso e ocupação do solo para os anos 2012 e 2019 (em hectares), para as categorias AGRÍCOLA, VEGETAÇÃO NATIVA e URBANA, projetado pelo método da Cadeia de Markov.

\begin{tabular}{|c|c|c|c|}
\hline & AGR & VEG & URB \\
\hline $\mathbf{2 0 1 2}$ & 33484.03 & 11124.45 & 6070.43 \\
\hline $\mathbf{2 0 1 9}$ & 33427.44 & 10128.49 & 7122.98 \\
\hline
\end{tabular}



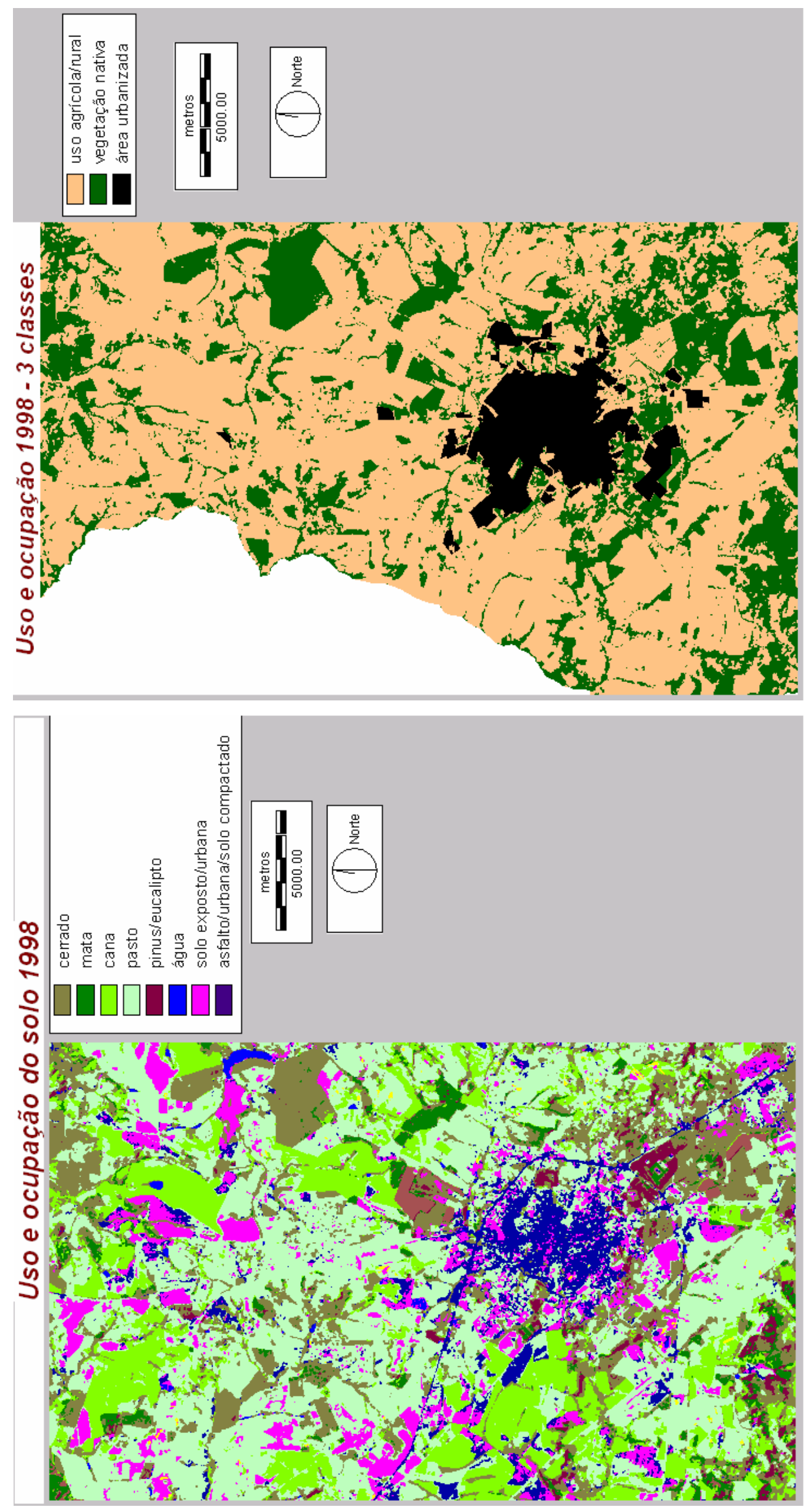

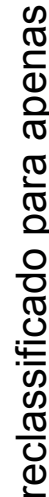

흘

(1) $\frac{m}{\alpha}$

ธั่

讨

क)

乙 Z

है।

ত্রে

ह

잉

Ð

증

$\sigma \stackrel{\sim}{\sim}$

চ

()

음 $\frac{U}{\alpha}$

$0 \div$

흥

을

잉

응 응

엉

约 $\frac{\Phi}{\pi}$

윽 똔

9

옥

บ)

ธ్

짐 
$?$
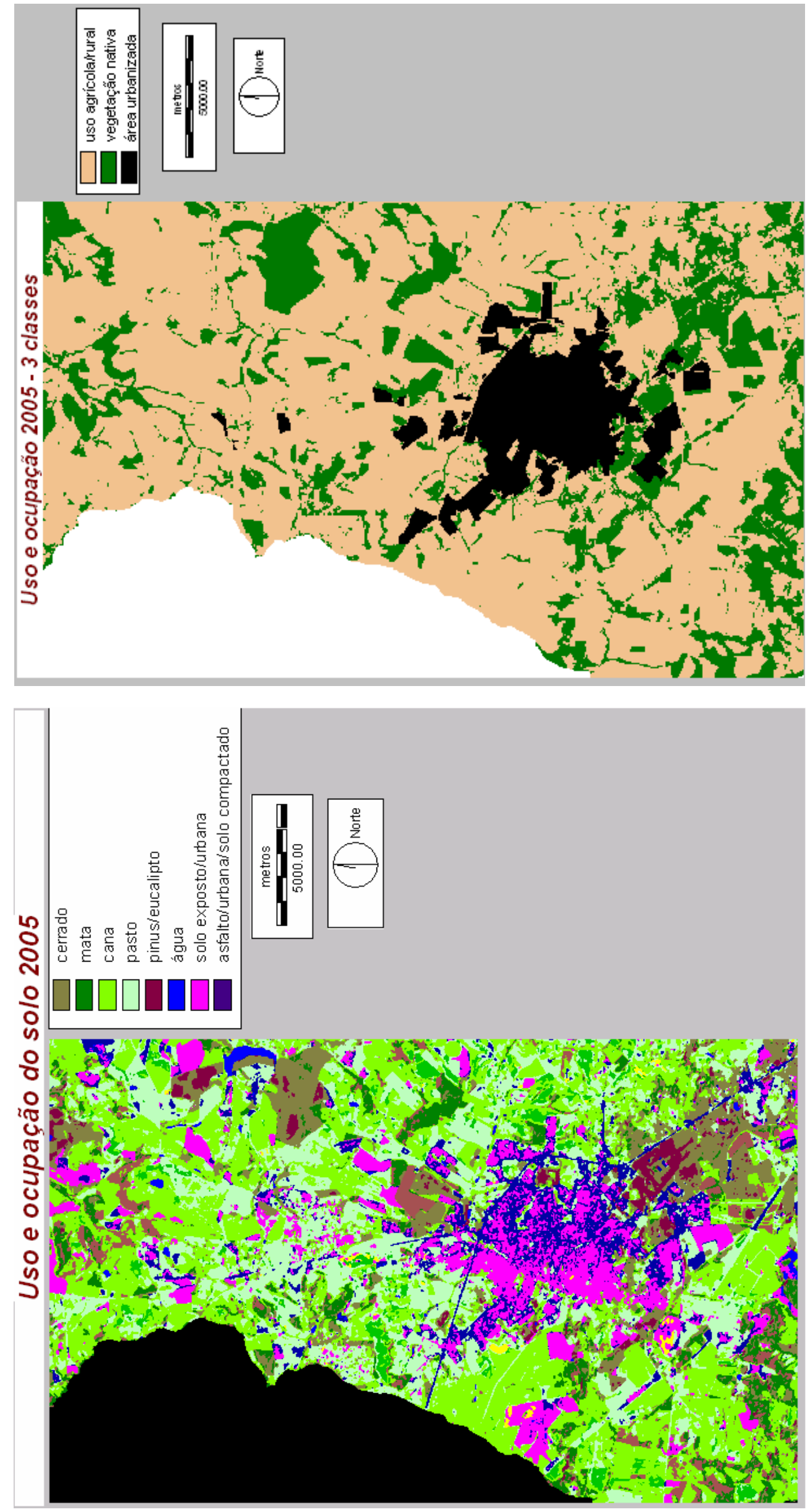

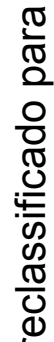

음

เ

잉

耐

它

$\varepsilon 0$

过

हᄐ

뜽

ま

징

누요

유 꿍

응

으늠

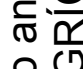

त(

สั 0

을

क

응 즌

용

엉

শั ত

윽 क

త్ర

(1)

을

I

ब

$\frac{\pi}{2}$
$\frac{2}{\pi}$
$\frac{\pi}{2}$
$\frac{\pi}{5}$
$\frac{\pi}{5}$ 


\subsubsection{Geração de cenários}

Fornecendo ao modelo informações referentes à área ocupada pelos estados 1 (NÃO-URBANA) e 2 (URBANA) no tempo inicial (2005) e final (2012 ou 2019) de modelagem, obtêm-se os mapas de uso do solo em 2012 e 2019. Para os diferentes cenários descritos no item 4.3.1.3, apresentam-se os resultados nas figuras 15 a 17.
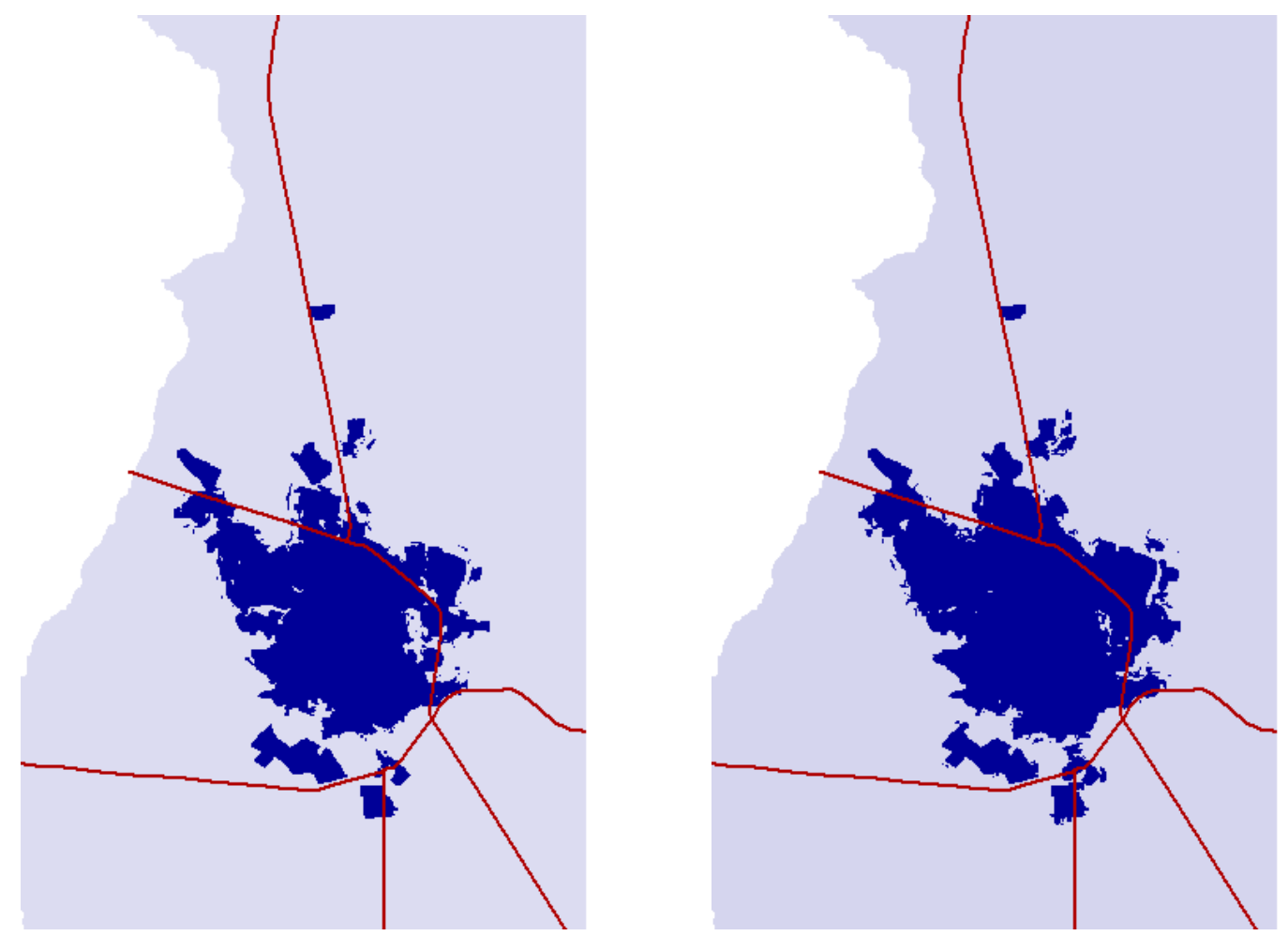

Figura 15. Mapas de uso e ocupação do solo para os anos 2012 (esq.) e 2019 (dir.), para as categorias NÃO-URBANA (claro) e URBANA (escuro), conforme Cenário I. 

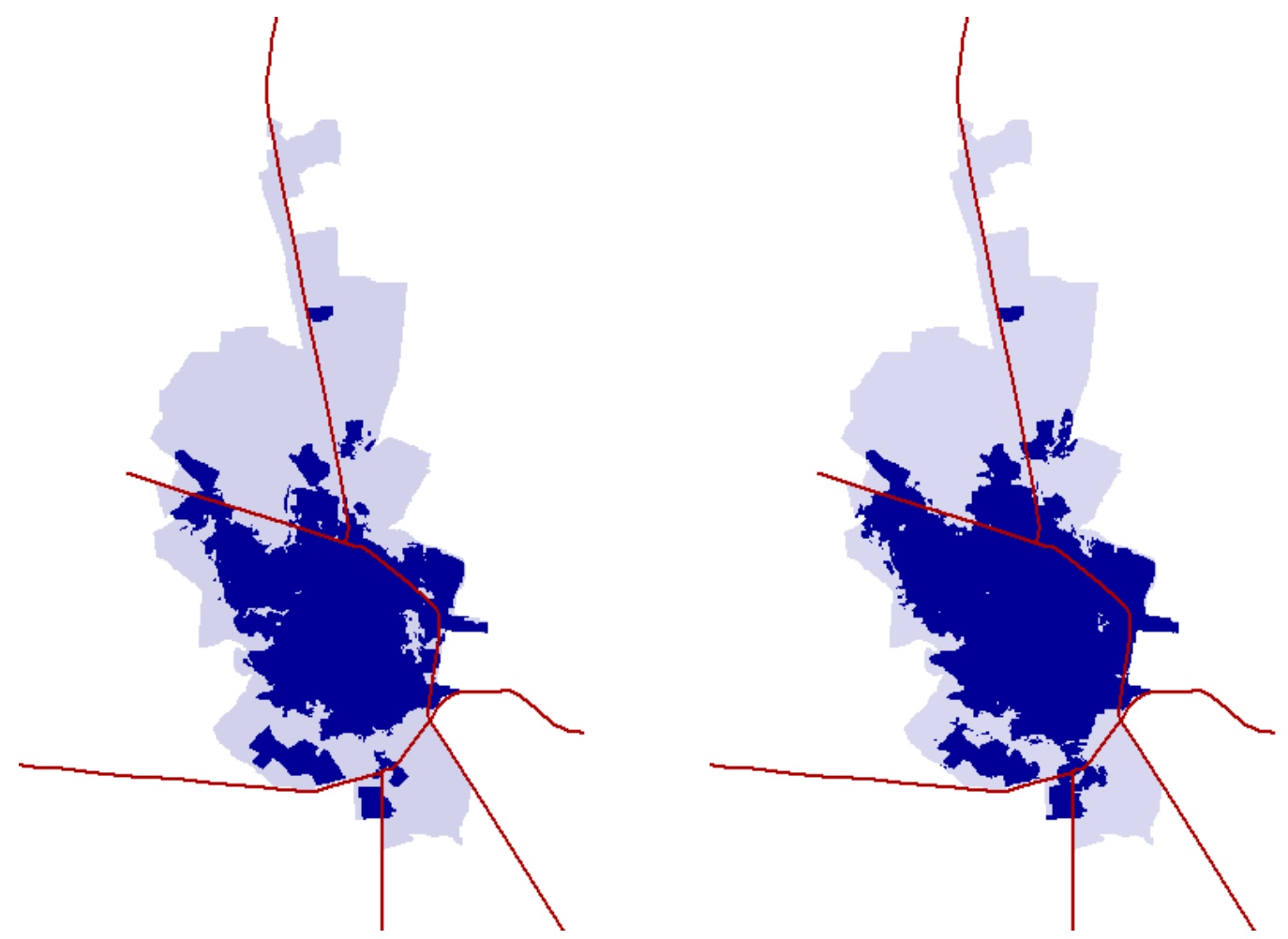

Figura 16. Mapas de uso e ocupação do solo para os anos 2012 (esq.) e 2019 (dir.), para as categorias NÃO-URBANA (claro) e URBANA (escuro), conforme Cenário II.
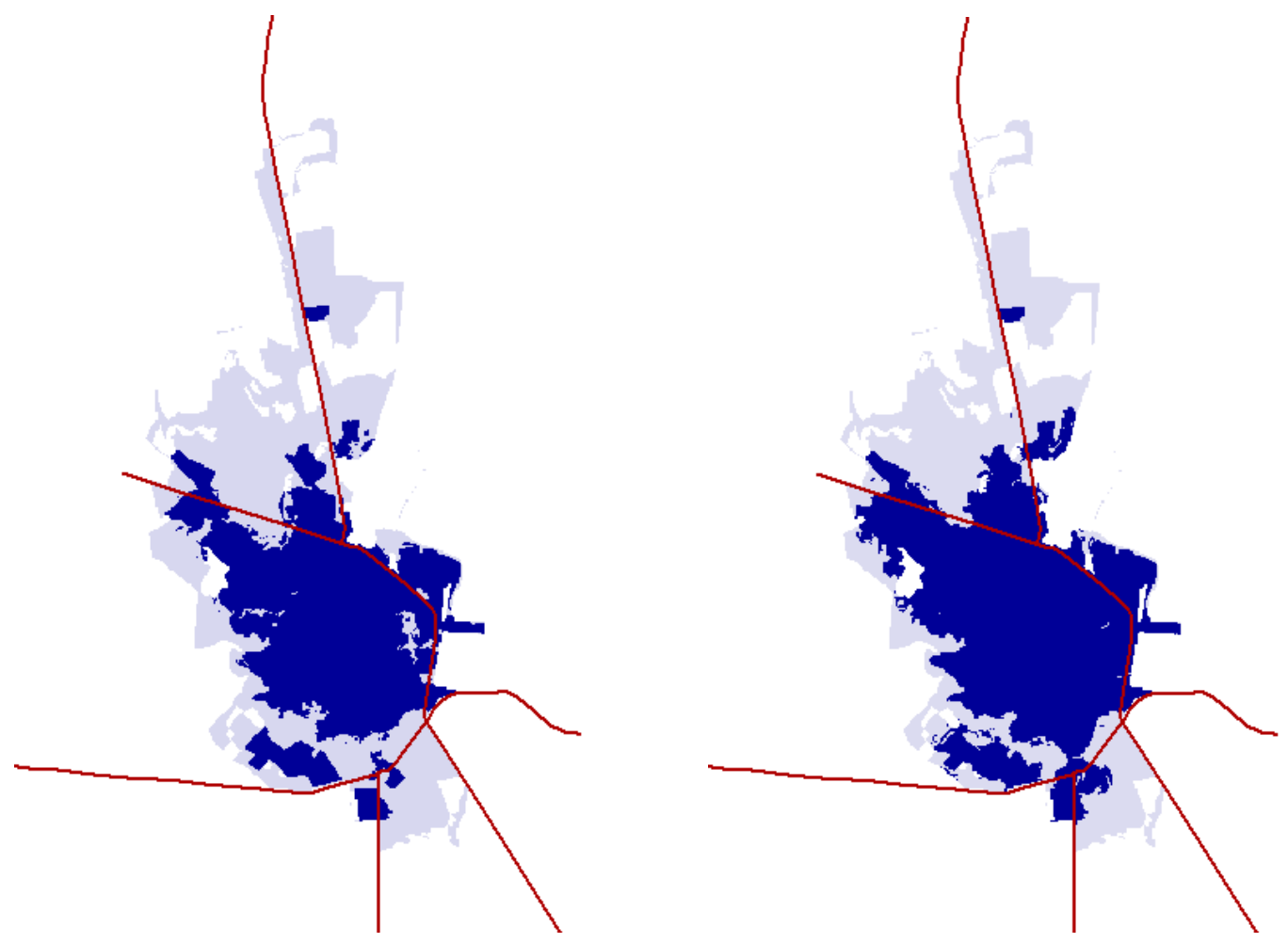

Figura 17. Mapas de uso e ocupação do solo para os anos 2012 (esq.) e 2019 (dir.), para as categorias NÃO-URBANA (claro) e URBANA (escuro), conforme Cenário III. 
5.2. Descrição da metodologia empregada na elaboração do zoneamento ambiental

\subsubsection{Avaliação da capacidade de carga do terreno}

Observando as considerações sobre a avaliação de carga do terreno efetuadas no item 4.3.2.1, o mapa de classes de Capacidade de Uso do Solo reclassificado de acordo com a sua aptidão para a ocupação urbana é apresentado na figura 18. Pela ponderação efetuada, é possível observar que a atual área urbana de São Carlos ocupa uma área predominantemente de média aptidão segundo a capacidade de carga do terreno. 

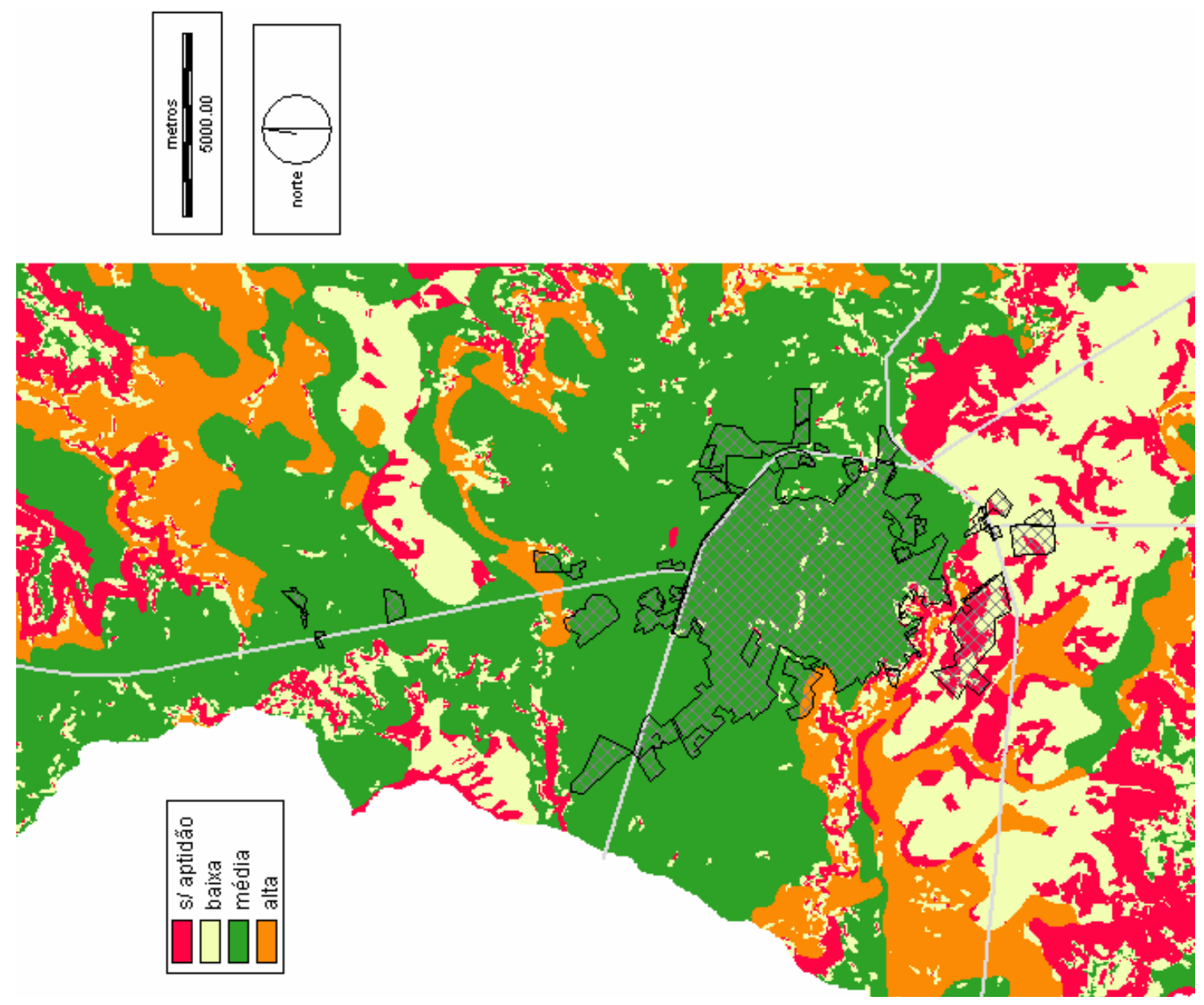

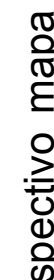

I 0

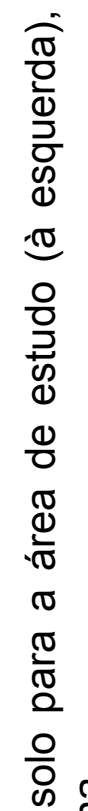

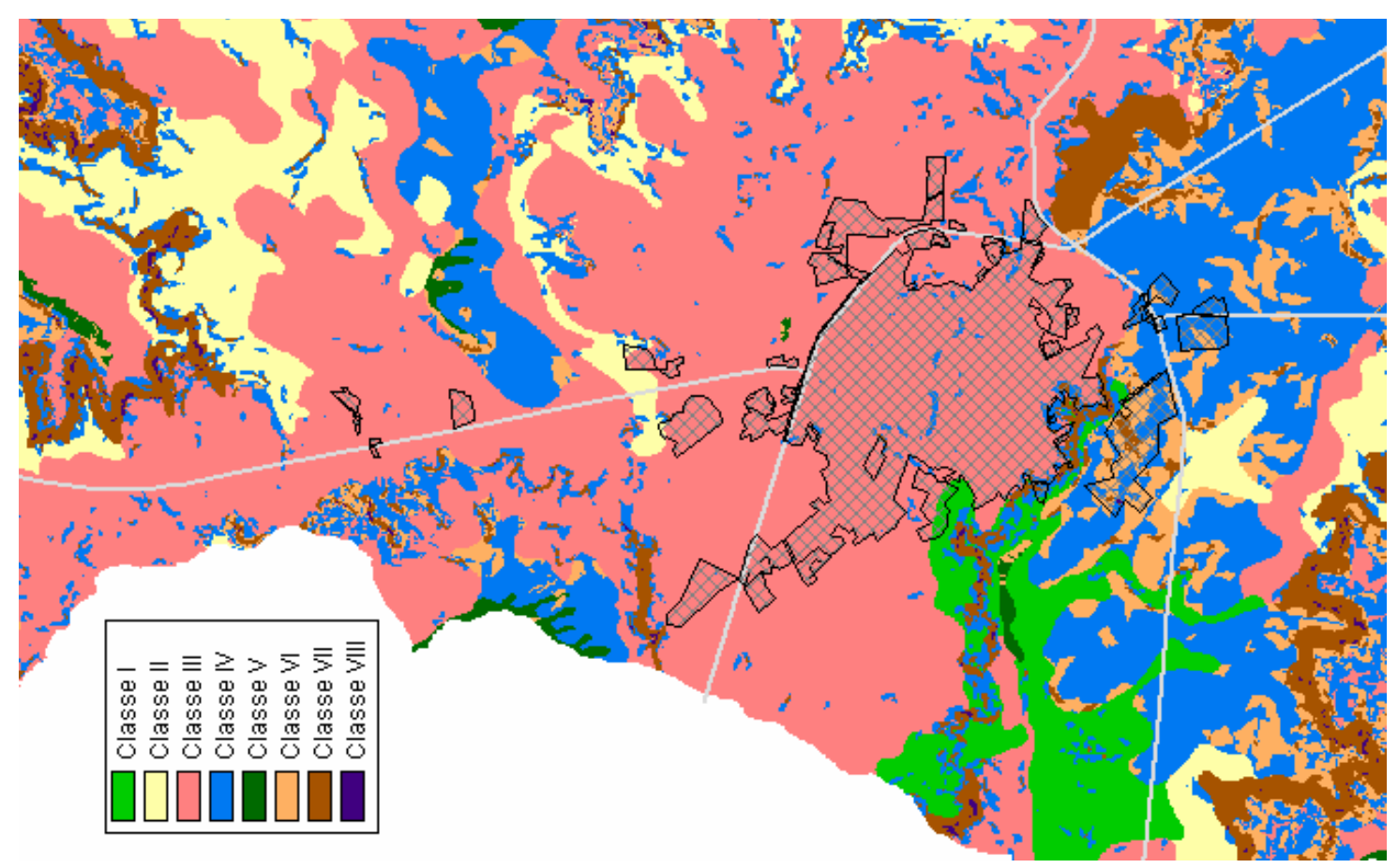

응 즁

ㅇ 은 응 쥬 잉 긍 ণิ 는 진 증 응 응 రิ 20 응 응 क त की क 원 웜 은 증 엉 $\sum^{\pi}$ 음 $\infty$ 직 $\frac{\mathscr{W}}{0}$ 


\subsubsection{Vulnerabilidade dos recursos hídricos subterrâneos}

O resultado da aplicação da metodologia para a avaliação da vulnerabilidade dos recursos hídricos subterrâneos descrita no item 4.3.2.2 é apresentado a seguir.

A figura 19 mostra o mapa de vulnerabilidade escalonado para o intervalo 0-255 (gerado pela Avaliação Multi-Criterial realizada) e o respectivo mapa reclassificado segundo a aptidão para a ocupação urbana associada a este tema.

Para toda a área de estudo verifica-se a predominância de valores intermediários para a vulnerabilidade dos recursos hídricos, conforme a ponderação efetuada. 


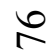

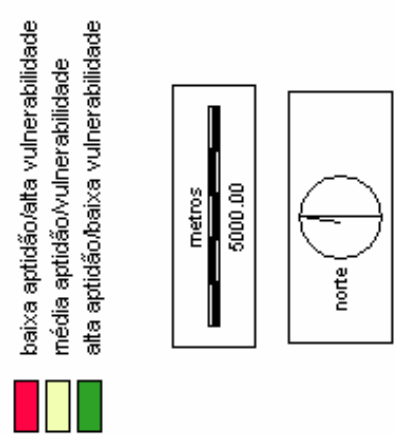

है
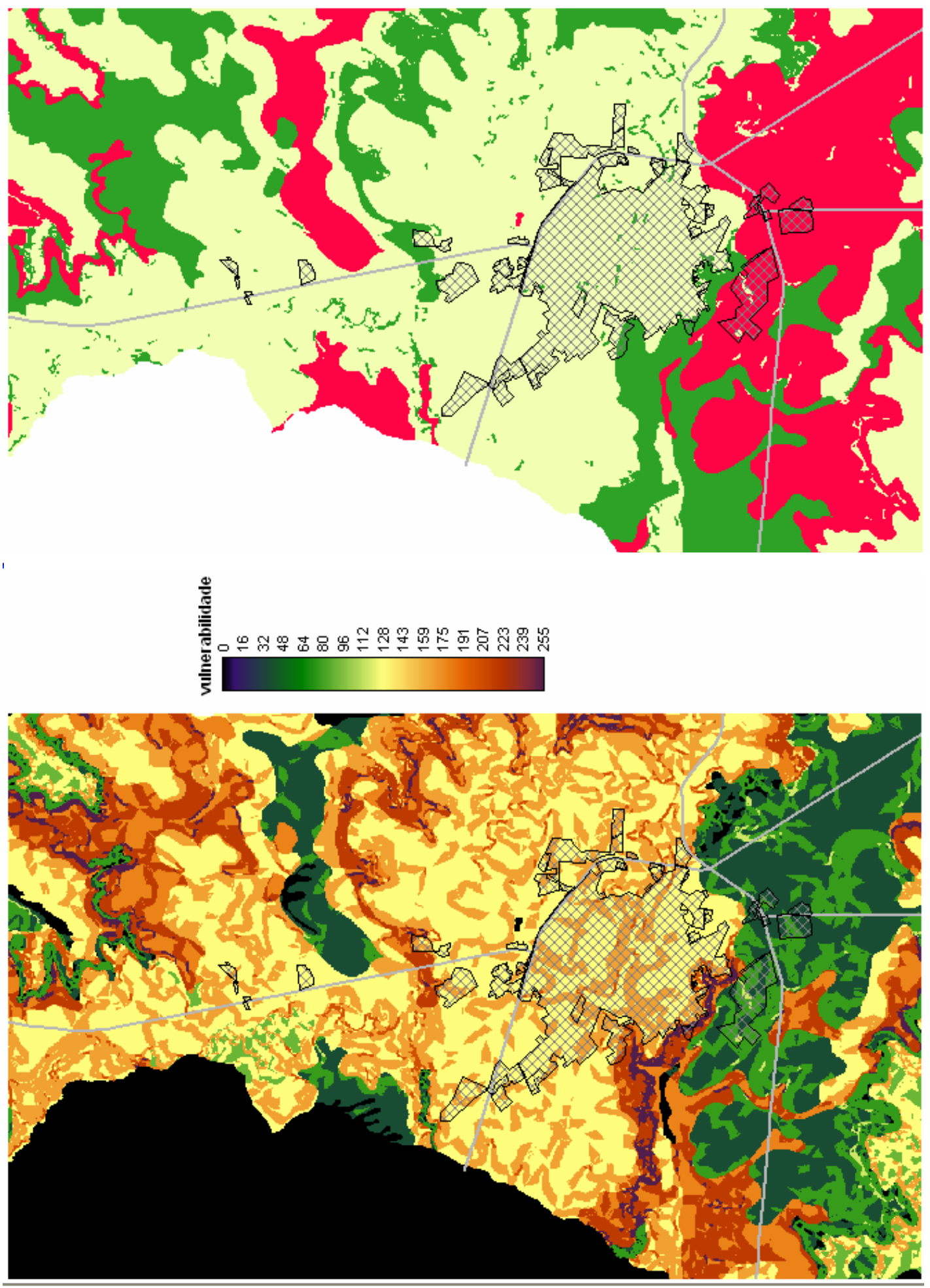
A figura 20, a seguir, apresenta um detalhamento do mapa anterior sobre a área ocupada pela malha urbana de São Carlos. É possível perceber que, em relação à vulnerabilidade dos recursos hídricos subterrâneos, toda a região ao sul da cidade apresenta alta vulnerabilidade, o que indica a necessidade de se avaliar com cautela a implantação de empreendimentos que representem risco às águas subterrâneas.

Tal necessidade é ainda maior quando se constata as condições que se apresentam para a ocupação dessas áreas atualmente, marcada por aglomerados urbanos e industriais implantados de modo reconhecidamente inadequado, e que constituem um fator de risco que deve ser contemplado no processo decisório.

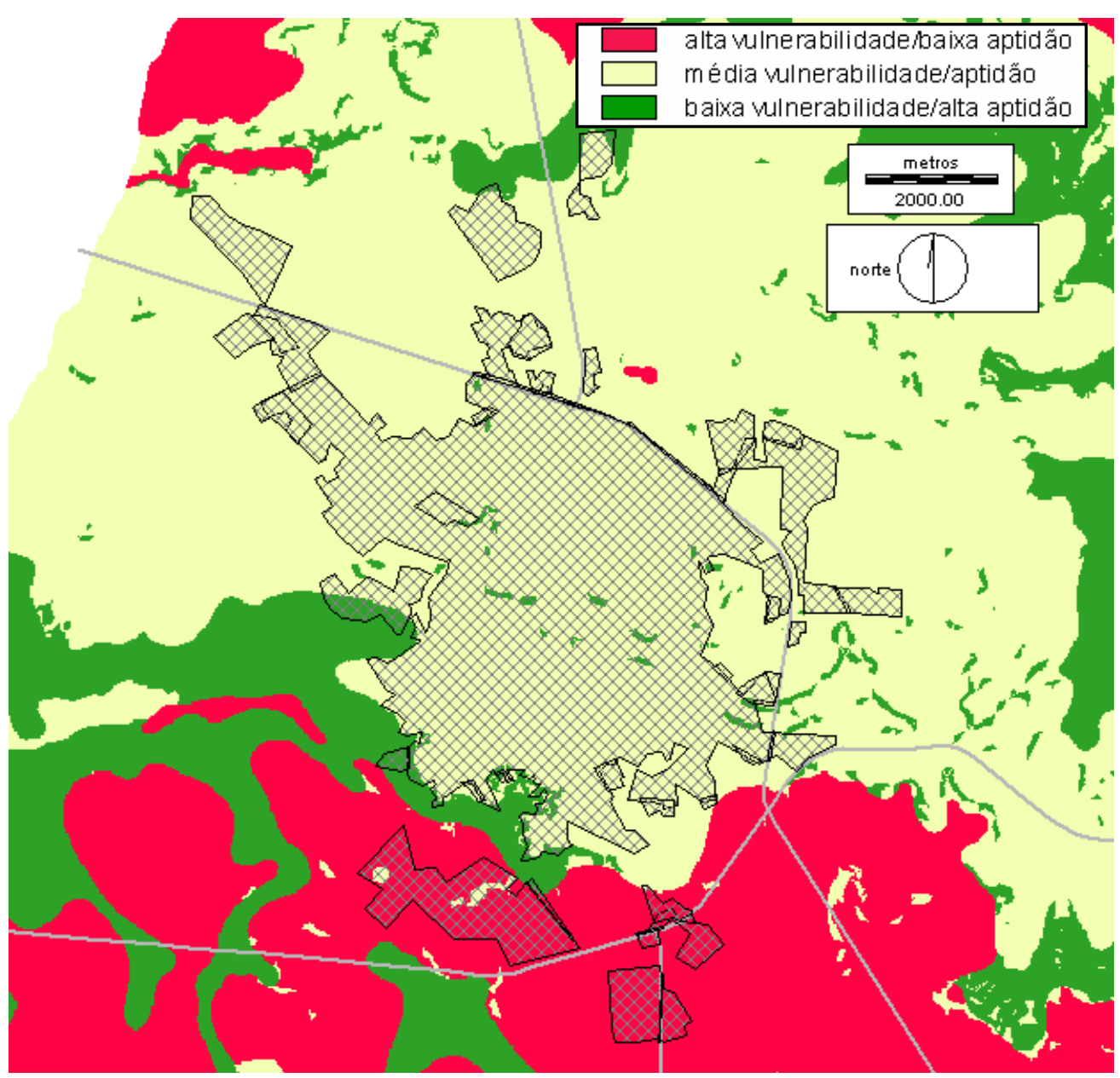

Figura 20. Detalhe sobre a malha urbana atual 


\subsubsection{Ponderação sobre os fatores}

Na figura 21 são apresentados os resultados das ponderações, descritas no item 4.3.2.3, para a geração dos mapas de "Aptidão do Terreno”, “Aptidão Geologia” e "Aptidão Mananciais".

A figura 22 apresenta o resultado do zoneamento ambiental efetuado para a avaliação da aptidão do território com relação à ocupação urbana, conforme ponderação descrita para elaborar o mapa "Aptidão Urbana". 
2
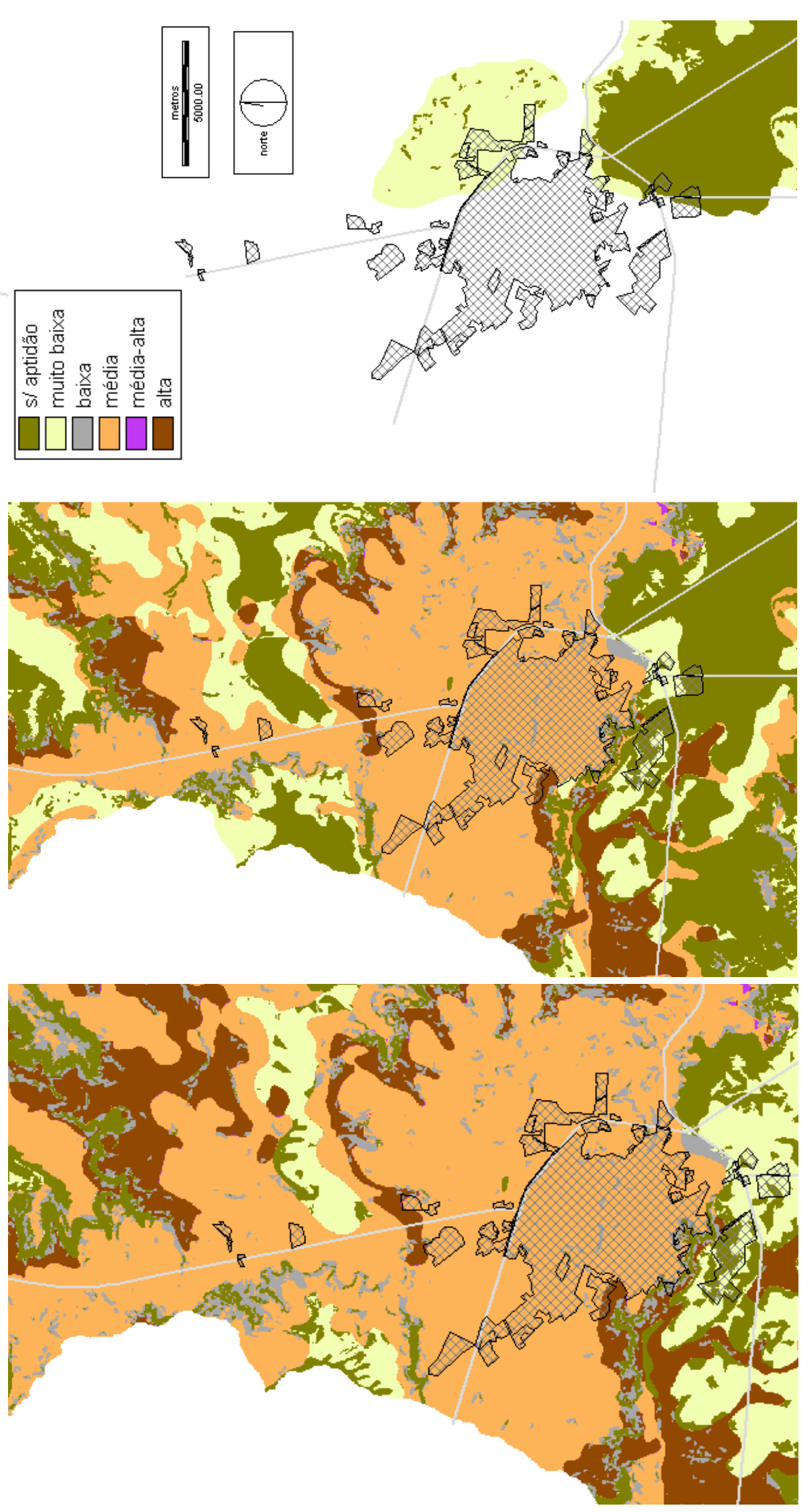

0
$\frac{0}{0}$
$=0$
$\frac{\pi}{0}$
$\frac{0}{0}$
0
0
0
0
$\frac{2 \pi}{0}$
$\frac{0}{0}$
$\frac{0}{1}$

을

$\stackrel{\oplus}{-}$

응

응

$\frac{10}{\frac{0}{0}}$

$\stackrel{\mathscr{D}}{\mathbb{E}}$

o

음

它

은 음

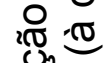

죽 :

응

त) ซ

흐 즘

○

증 중

운 웅

ஸे

줗 

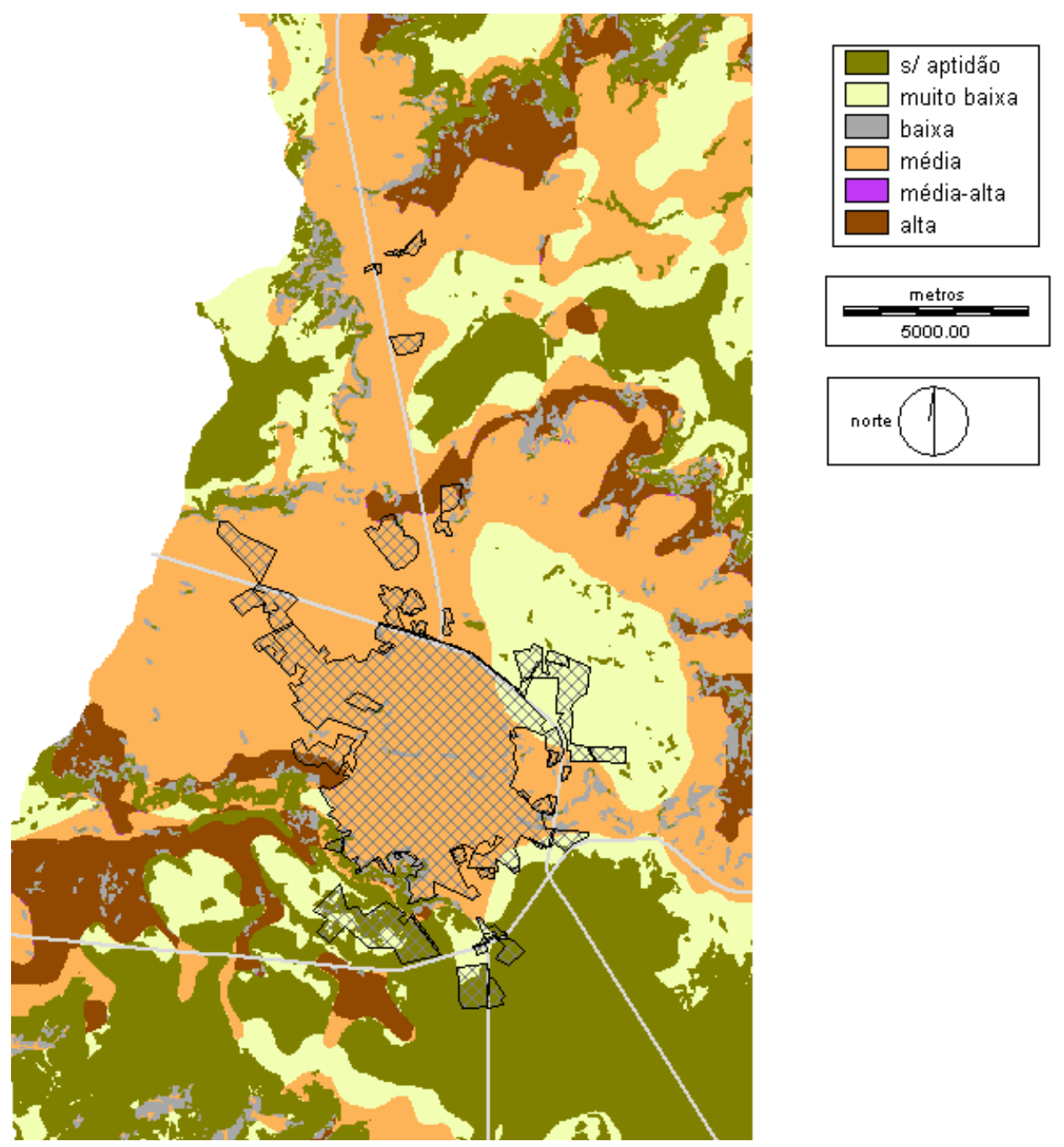

Figura 22. Combinação dos temas avaliados, segundo ponderação descrita (zoneamento ambiental para ocupação urbana).

\subsection{Aplicação conjunta com outros instrumentos de gestão ambiental}

As informações geradas após a realização dos procedimentos descritos suscitam discussões relacionadas às formas de aplicação da modelagem do uso e ocupação do solo (e seus métodos correspondentes) que permita sua integração ao contexto da gestão ambiental, numa abordagem preventiva quanto à minimização de riscos e de impactos ambientais relacionados aos padrões de ocupação territorial que venham a ser identificados como prejudiciais ao meio. 
Nesse sentido, evidenciam-se possibilidades de aplicação conjunta a pelo menos três instrumentos de gestão ambiental: zoneamento ambiental, avaliação de impactos ambientais e licenciamento de atividades (em especial relacionados à atuação dos órgãos - estaduais e municipais - de meio ambiente).

\subsubsection{Aplicações com o zoneamento ambiental}

A modelagem efetuada no presente trabalho, integrada ao zoneamento ambiental, permite analisar as tendências de ocupação no território identificadas para a área de estudo quanto às classes de aptidão para a expansão urbana. A tabela 15 apresenta a evolução da ocupação urbana em função das classes de aptidão indicadas no zoneamento ambiental, de acordo com a projeção efetuada.

Tabela 15 - Evolução da área urbanizada em função das classes de aptidão indicadas no zoneamento ambiental, de acordo com os cenários elaborados.

\begin{tabular}{|c|c|c|c|c|c|c|c|}
\hline \multirow{2}{*}{\multicolumn{2}{|c|}{ ÁREA (ha) }} & \multicolumn{6}{|c|}{ Classes de aptidão (ZONEAMENTO AMBIENTAL) } \\
\hline & & s/ aptidão & muito baixa & baixa & média & média-alta & alta \\
\hline \multicolumn{2}{|r|}{2005} & 372.24 & 562.68 & 122.04 & 3430.44 & 0.72 & 45.72 \\
\hline \multirow{5}{*}{$\begin{array}{l}\overline{0} \\
: \frac{0}{\pi} \\
\frac{0}{0} \\
0\end{array}$} & 2012 & 372.24 & 828.00 & 122.04 & 4200.12 & 1.80 & 45.72 \\
\hline & 2019 & 413.28 & 1066.32 & 158.40 & 4919.40 & 2.88 & 45.72 \\
\hline & $2012 / 2005$ & $0 \%$ & $+47 \%$ & $0 \%$ & $+22.4 \%$ & $+150 \%$ & $0 \%$ \\
\hline & $2019 / 2012$ & $+11 \%$ & $+28.8 \%$ & $+29.8 \%$ & $+17.1 \%$ & $+60 \%$ & $0 \%$ \\
\hline & $2019 / 2005$ & $+11 \%$ & $+89.5 \%$ & $+29.8 \%$ & $+43.4 \%$ & $+300 \%$ & $0 \%$ \\
\hline \multirow{5}{*}{ 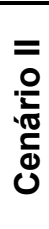 } & 2012 & 370.08 & 812.88 & 121.32 & 4257.72 & 1.80 & 45.72 \\
\hline & 2019 & 439.92 & 992.88 & 174.96 & 5039.28 & 3.24 & 45.72 \\
\hline & $2012 / 2005$ & $-0.6 \%$ & $+44.5 \%$ & $-0.6 \%$ & $+24.1 \%$ & $+150 \%$ & $0 \%$ \\
\hline & $2019 / 2012$ & $+18.9 \%$ & $+22.1 \%$ & $+44.2 \%$ & $+18.4 \%$ & $+80 \%$ & $0 \%$ \\
\hline & $2019 / 2005$ & $+18.2 \%$ & $+76.5 \%$ & $+43.4 \%$ & $+46.9 \%$ & $+350 \%$ & $0 \%$ \\
\hline \multirow{5}{*}{ 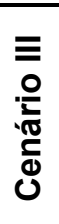 } & 2012 & 369.72 & 800.28 & 122.04 & 4267.80 & 1.80 & 45.72 \\
\hline & 2019 & 507.24 & 990.36 & 191.52 & 4958.28 & 2.88 & 45.72 \\
\hline & $2012 / 2005$ & $-0.7 \%$ & $+42.2 \%$ & $0 \%$ & $+24.4 \%$ & $+150 \%$ & $0 \%$ \\
\hline & $2019 / 2012$ & $+37.2 \%$ & $+23.8 \%$ & $+56.9 \%$ & $+16.2 \%$ & $+60 \%$ & $0 \%$ \\
\hline & $2019 / 2005$ & $+36.3 \%$ & $+76.0 \%$ & $+56.9 \%$ & $+44.5 \%$ & $+300 \%$ & $0 \%$ \\
\hline
\end{tabular}


A interpretação da tabela apresentada conduz a algumas observações:

1. Para os instantes avaliados $(2005,2012$ e 2019$)$, de modo geral entre os cenários apresentados, é verificado um aumento na urbanização de áreas classificadas como "sem aptidão", "muito baixa" e "baixa". Nesse aspecto, verifica-se que o Cenário III está relacionado à maior ocupação das classes "sem aptidão" e "baixa", assim como o Cenário I se relaciona à maior ocupação da classe "muito baixa";

2. O Cenário II, por sua vez, é o que apresenta a maior ocupação em termos absolutos das classes "média", "média-alta" e "alta", passando (na soma das classes) de 3.477 hectares em 2005 para 5.088 hectares em 2019. Pode-se inferir daí que seria preferível que se confirmassem as condições que definem este cenário, quais sejam, a efetivação do controle da expansão urbana e a observação dos limites do Perímetro Urbano e da Zona de Expansão urbana definidos pelo Plano Diretor;

3. A classe de aptidão "média-alta" não é ocupada de modo significativo em nenhum dos cenários elaborados. Por sua vez, a classe "alta" não apresenta variação ao longo do tempo, para os três cenários apresentados, mantendo-se os valores de 2005 (45,72 hectares);

4. Em termos relativos, desconsiderando-se as classes "média-alta" e "alta", e considerando o intervalo 2005-2012, a expansão urbana ocorre com mais intensidade sobre a classe de aptidão "muito baixa", nas condições do Cenário I (acréscimo de 47\%). Para o intervalo 2012-2019, a expansão é mais intensa sobre a classe "baixa", conforme o Cenário III (variação próxima a 57\%). 


\subsubsection{Aplicações em Avaliação de Impactos Ambientais}

A expansão urbana projetada para os anos de 2012 e 2019 permite avaliar o nível de pressão sobre os recursos naturais que se apresentam para o território estudado. A fim de ilustrar e discutir sobre a aplicação da modelagem do uso e ocupação do solo num processo de avaliação de impactos ambientais, apresentamse algumas reflexões sobre as projeções para quatro bacias hidrográficas que integram a área urbana do município, duas das quais são utilizadas atualmente para a captação de água para abastecimento.

O foco da análise sobre as bacias hidrográficas é justificado pelos impactos ambientais associados à urbanização. Modificações no regime hidrológico e degradação dos cursos de água por assoreamento ou contaminação por efluentes domésticos e industriais estão entre os principais impactos relacionados ao processo de urbanização de bacias hidrográficas. Essa análise é ainda mais justificada quando se trata das bacias de captação de água superficial para abastecimento público, dada a sua importância estratégica.

Tomando como base as bacias hidrográficas dos córregos do Gregório e Santa Maria do Leme, e as bacias de captação do Monjolinho/Espraiado e do Feijão, conforme ilustrado na figura 23, verifica-se na tabela 16 a evolução de sua ocupação para as diferentes datas e cenários projetados. 


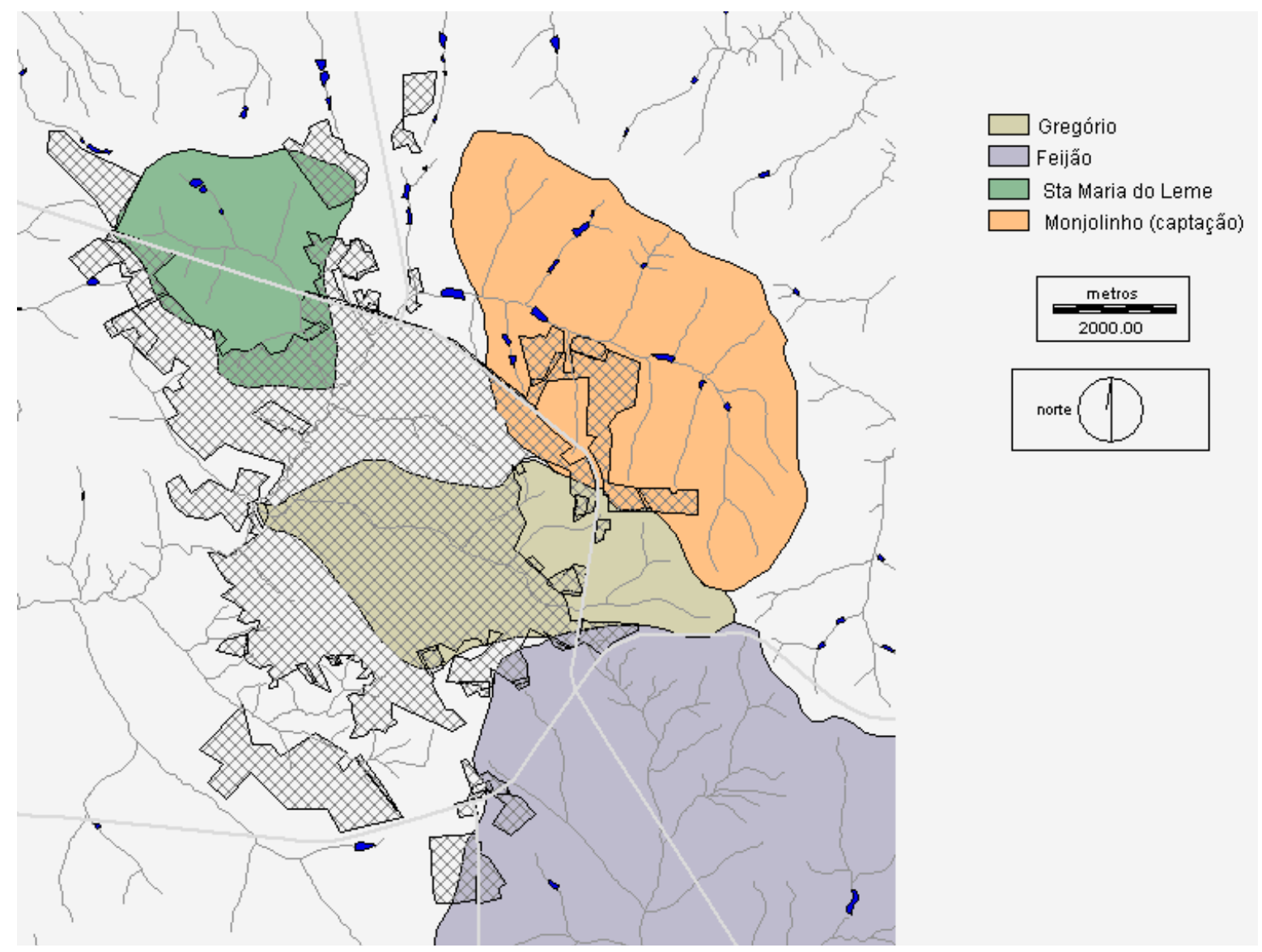

Figura 23. Localização das bacias hidrográficas dos córregos do Gregório, Santa Maria do Leme, e das bacias de captação do Monjolinho/Espraiado e do Feijão, em relação à malha urbana atual.

Tabela 16 - Evolução da área urbanizada sobre as bacias hidrográficas, de acordo com os cenários elaborados.

\begin{tabular}{|c|c|c|c|c|c|c|}
\hline \multirow{3}{*}{ atual } & & & Gregório & Sta Maria & Feijão & Monjolinho/Espraiado \\
\hline & \multirow{2}{*}{2005} & área (ha) & 1076.04 & 295.2 & 159.84 & 366.12 \\
\hline & & $\%$ da bacia & $66.1 \%$ & $26.6 \%$ & $0.69 \%$ & $13.8 \%$ \\
\hline \multirow{4}{*}{ Cenário I } & \multirow{2}{*}{2012} & área (ha) & 1213.92 & 435.96 & 235.44 & 534.6 \\
\hline & & $\%$ da bacia & $74.6 \%$ & $39.3 \%$ & $1.02 \%$ & $20.1 \%$ \\
\hline & \multirow{2}{*}{2019} & área (ha) & 1363.32 & 622.44 & 307.44 & 690.48 \\
\hline & & $\%$ da bacia & $83.7 \%$ & $56.1 \%$ & $1.34 \%$ & $25.9 \%$ \\
\hline \multirow{4}{*}{ Cenário II } & \multirow{2}{*}{2012} & área (ha) & 1189.8 & 460.44 & 231.12 & 520.2 \\
\hline & & $\%$ da bacia & $73.1 \%$ & $41.5 \%$ & $1.00 \%$ & $19.5 \%$ \\
\hline & \multirow{2}{*}{2019} & área (ha) & 1289.52 & 691.2 & 311.76 & 593.28 \\
\hline & & $\%$ da bacia & $79.2 \%$ & $62.3 \%$ & $1.35 \%$ & $22.3 \%$ \\
\hline \multirow{4}{*}{ Cenário III } & \multirow{2}{*}{2012} & área (ha) & 1215 & 495 & 239.04 & 495.36 \\
\hline & & $\%$ da bacia & $74.6 \%$ & $44.6 \%$ & $1.04 \%$ & $18.6 \%$ \\
\hline & \multirow{2}{*}{2019} & área (ha) & 1296.72 & 738 & 358.56 & 552.24 \\
\hline & & $\%$ da bacia & $79.6 \%$ & $66.5 \%$ & $1.56 \%$ & $20.7 \%$ \\
\hline
\end{tabular}


Partindo da análise das informações apresentadas na tabela anterior, são efetuadas algumas considerações com relação aos impactos da urbanização futura sobre as bacias indicadas:

Bacia do Gregório - considerada uma bacia hidrográfica crítica em termos de escoamento de águas pluviais, destacada pela freqüência e intensidade com que ocorrem eventos de inundação. Nesse caso, o Cenário I constitui a situação mais severa em termos da ocupação desta bacia, embora os demais cenários também apontem para índices de ocupação que devem ser evitados. Dos atuais 66\% ocupados pela urbanização, as projeções para o Cenário I indicam uma ocupação de $75 \%$ em 2012 e de $84 \%$ em 2019, o que reforça a necessidade de adequação da ocupação futura no sentido de se mitigar os efeitos das inundações ${ }^{19}$;

Bacia do Santa Maria do Leme - atualmente ocupada pela urbanização em apenas $27 \%$ de seu território. Contudo apresenta a maior variação em termos de área urbanizada, dentre as cinco bacias analisadas, o que reflete a maior tendência para a urbanização desta bacia sobre as demais. As projeções efetuadas para o Cenário III indicam que essa variação pode chegar a $+67 \%$ no período $2005-2012$ e a $+150 \%$ entre 2005 e 2019 ;

Bacia de captação do ribeirão do Feijão - devido às dimensões desta bacia (superior a 23.000 ha) e à sua localização com relação à área urbana (fora dos eixos principais de expansão), as projeções para a expansão urbana indicam que a ocupação desta bacia não deverá alcançar um nível significativo em área (mantidas as condições aplicadas à modelagem). De fato, os três cenários projetados indicam que a área urbanizada deverá atingir um nível próximo a $1 \%$ em 2012, sem chegar

\footnotetext{
${ }^{19}$ Para um maior detalhamento sobre as possibilidades de adequação mencionadas ver as colocações de Boldrin (2005), que recentemente avaliou a capacidade de escoamento do canal do córrego do Gregório para diferentes cenários de ocupação no trecho inicial desta bacia.
} 
aos $1,7 \%$ em 2019. Há que se considerar, contudo, que a ocupação urbana a partir da malha atual incide diretamente sobre a cabeceira desta bacia, podendo impactar de forma negativa algumas nascentes formadoras de tributários do ribeirão do Feijão. Além disso, praticamente toda a urbanização futura na bacia do Feijão, segundo as projeções efetuadas para os três cenários, ocorrerá em área classificada como "sem aptidão" para a ocupação urbana;

Bacia de captação do Monjolinho/Espraiado - pela proximidade com a área urbana, trata-se de um manancial que apresenta alto valor do ponto de vista estratégico. Atualmente, existem indicativos de diminuição na capacidade de produção e na quantidade da água captada ${ }^{20}$, o que reforça a preocupação com a urbanização desta bacia. As projeções efetuadas indicam que esta bacia apresenta forte tendência à urbanização, com variações que chegam a $46 \%$ de acréscimo na urbanização considerando-se o período 2005-2012 (conforme o Cenário I).

\subsubsection{Aplicações no processo de licenciamento de atividades}

O processo de expansão urbana traz consigo novos empreendimentos vinculados à urbanização do território. Em grande medida, tais empreendimentos irão demandar pela análise e emissão de licenças ambientais, de acordo com os preceitos legais vigentes.

As informações geradas pela aplicação da modelagem para projeções do uso e ocupação do solo são úteis, dentre outros aspectos, para que os órgãos ambientais

\footnotetext{
${ }^{20}$ A esse respeito, ver a associação entre o processo de urbanização diminuição da quantidade e qualidade de água captada na bacia do Monjolinho/Espraiado efetuada no trabalho de Pelatti (2004).
} 
competentes possam antecipar demandas futuras, e com isso aumentar a eficácia em sua atuação.

Para ilustrar a possibilidade de aplicação conjunta da modelagem nos procedimentos de licenciamento ambiental, discutem-se a seguir possíveis desdobramentos na atuação de um órgão ambiental com atribuição específica de emissão de licenças ambientais, integrado ao sistema estadual de gestão ambiental.

Mais precisamente, o Departamento Estadual de Proteção aos Recursos Naturais (DEPRN) é responsável, no Estado de São Paulo, pela análise e emissão de licenças para o corte ou supressão de espécies arbóreas, bem como fiscalizar e atuar pela manutenção de áreas de preservação permanente e de reservas legais. 0 DEPRN ainda atua, dentre outras coisas, com a emissão de pareceres para a expedição de diretrizes para implantação de loteamentos urbanos.

De modo a antecipar as demandas, a espacialização da expansão urbana para anos futuros possibilita a reflexão sobre a melhor estratégia a ser adotada para determinadas regiões.

No presente caso, as projeções para os três cenários indicam que há uma perspectiva de expansão urbana sobre cerca de 200 hectares de área coberta com vegetação nativa até 2012, que chegaria a 440 hectares (conforme o Cenário III) até o ano 2019 (tabela 17).

Tabela 17 - Quantidade de vegetação nativa (em hectares) que sofreria interferência da urbanização, de acordo com os cenários projetados.

\begin{tabular}{|c|cc|}
\hline & $\mathbf{2 0 1 2}$ & $\mathbf{2 0 1 9}$ \\
\hline Cenário I & 196.56 & 394.92 \\
Cenário II & 209.88 & 425.88 \\
Cenário III & 204.48 & 440.64 \\
\hline
\end{tabular}


É possível notar que o cenário III apresenta, de modo geral, uma maior tendência à ocupação de áreas de vegetação nativa (figura 26). Segundo as informações obtidas não há, atualmente, nenhuma área averbada que constitua obstáculo à urbanização. Assim, muito provavelmente, as áreas indicadas nas projeções seriam objeto de pressão para que tivessem sua vegetação removida.

Nesse sentido, as informações apresentadas poderiam ser utilizadas pelo órgão ambiental para antecipar tal situação, dando início a um processo de intensificação na fiscalização dessas áreas, bem como de regularização das áreas de Reserva Legal nas propriedades, visando a preservação dos fragmentos de vegetação nativa. Uma outra possibilidade diz respeito à atuação do órgão ambiental no sentido de orientar a averbação de Reserva Legal em áreas frágeis, indicadas como prioritárias para a preservação ${ }^{21}$.

\subsection{Discussão geral}

Os resultados obtidos para as aplicações apresentadas indicam que, no caso específico de São Carlos, mantidas as tendências atuais, e para os três cenários de ocupação avaliados, a expansão urbana continuaria avançando sobre áreas de baixa aptidão para a urbanização (em termos da capacidade de suporte apresentada pelos fatores ambientais), de acordo com a ponderação efetuada para a elaboração do zoneamento ambiental.

As projeções efetuadas para diferentes cenários de ocupação indicam, ainda, que a pressão sobre os recursos hídricos e os fragmentos de vegetação nativa

\footnotetext{
${ }^{21}$ Com relação a este aspecto, o trabalho de Ranieri (2004) apresenta uma proposta para a identificação de áreas prioritárias para preservação a partir de critérios ambientais.
} 
seguirá intensa, caso não sejam adotadas medidas que modifiquem o atual padrão de ocupação do território, basicamente ditado pelas condições de infra-estrutura viária e pelo mercado imobiliário.

De modo geral, o cenário III apresenta-se mais desfavorável com relação à aptidão do meio que deverá ser urbanizado (indicada pelo zoneamento ambiental), ao percentual de ocupação de certas bacias hidrográficas (exceto pela bacia de captação do Monjolinho/Espraiado), e quanto à pressão sobre os remanescentes de vegetação nativa situados próximos à malha urbana atual.

Tal cenário é gerado pela suposição de que a expansão urbana a partir da malha atual deverá ficar contida pelos limites do perímetro urbano e da zona de expansão urbana, observando-se as disposições contidas no Plano Diretor para o município, além de não ocupar áreas de empreendimentos já implantados (como condomínios de chácaras, instituições de pesquisa, empreendimentos privados de grande porte) e respeitar as áreas de Reserva Legal já averbadas.

Uma primeira reflexão sobre os resultados verificados para este cenário pode levar à conclusão de se tratar de uma conseqüência natural das restrições à ocupação apresentadas (menos área disponível para a ocupação urbana significaria mais "chance" de se ocupar áreas de baixa aptidão). Contudo, há que se verificar se tal comportamento não refletiria justamente um planejamento que tem atendido fundamentalmente aos interesses do mercado, sobrepondo-os aos interesses ambientais. 


\section{CONCLUSÕES E CONSIDERAÇÕES FINAIS}

A aplicação da modelagem para a projeção das alterações do uso e ocupação do solo se mostrou uma ferramenta de apoio à decisão extremamente útil, sobretudo, para a produção de informações que permitam avaliar as conseqüências sobre os fatores ambientais que compõem o território estudado, a partir de diferentes cenários de desenvolvimento.

Destaca-se, nesse sentido, a facilidade para a geração de novos cenários a partir da base de dados inicial, modificando-se determinados parâmetros empregados na modelagem. Uma outra vantagem verificada pelo presente trabalho, relacionada ao ferramental tecnológico empregado, refere-se à possibilidade quase que ilimitada de incorporar novas informações, que venham a compor outros parâmetros para a utilização na modelagem.

Com relação ao objetivo geral do trabalho, verificou-se que a aplicação conjunta do método de projeção do uso e ocupação do solo do território estudado com os instrumentos de política ambiental induz os tomadores de decisão à adoção de uma postura preventiva no que diz respeito a alterações significativas que 
venham a ocorrer, contribuindo para a identificação de impactos ambientais que deveriam ser evitados.

A projeção da expansão urbana para os anos de 2012 e 2019, a partir das tendências identificadas para o período 1998-2005, permitiu identificar com clareza as necessidades de uma ação preventiva quanto à minimização de riscos e de impactos ambientais, alterando-se os padrões de ocupação territorial identificados como prejudiciais ao meio, no sentido de procurar adequar os empreendimentos urbanos à aptidão apresentada pelo meio. Por sua vez, a utilização integrada ao instrumento zoneamento ambiental, elaborado para a determinação da aptidão do meio físico do território frente à ocupação urbana, também contribui para a detecção da necessidade de correção dos empreendimentos que se apresentarem incompatíveis frente a capacidade de suporte ambiental do meio.

A utilização conjunta da modelagem com outros instrumentos de política ambiental, como avaliação de impactos ambientais e licenciamento ambiental de atividades, conforme apresentado no presente trabalho, também contribui para dinamizar e otimizar a gestão ambiental, sobretudo no que diz respeito ao processo de tomada de decisão. Particularmente nesse sentido, o trabalho ilustra como seria benéfica ao órgão ambiental a utilização do ferramental explorado, no sentido do estabelecimento de prioridades de atuação com relação a pontos considerados críticos.

As avaliações efetuadas discutem algumas maneiras de se empregar a modelagem como ferramenta de integração e avaliação das informações disponíveis, que forneçam respostas confiáveis. Cabe destacar que modelos mais completos e mais eficientes tendem a se tornar mais complexos (ou mais caros) na 
medida em que pretendem incluir diferentes agentes (sociais, econômicos e culturais, inclusive) na explicação de um determinado fenômeno.

Uma vez que as informações apresentadas contribuem para a identificação (e visualização) de pontos críticos para o desenvolvimento do território, em termos da geração de impactos ao meio ambiente, verifica-se a importância da modelagem como ferramenta de apoio à decisão. Tais informações devem, portanto, ser produzidas com critério e disponibilizadas à sociedade para que integrem o processo de tomada de decisão.

Além disso, a integração dos métodos de projeção das alterações no uso do solo com os instrumentos de política ambiental, conforme apresentado no presente trabalho, será tão mais eficaz quanto maior a eficácia dos canais de participação da sociedade no processo decisório. Tal afirmação é especificamente válida em se tratando da gestão do espaço público, em que a sociedade deveria ser ao mesmo tempo agente de indução e fiscalização das ações do poder público.

Nesse sentido, a utilização conjunta de modelos de projeção das alterações de uso e ocupação do solo e de instrumentos de política ambiental pode contribuir para suprir uma importante lacuna, relacionada à informação disponibilizada à sociedade no momento de sua participação, que tem sido reiteradamente destacada na literatura.

Pelas informações e discussões apresentadas no presente trabalho, conclui-se que a modelagem para a projeção das alterações no uso e ocupação do solo do território pode contribuir significativamente para o equacionamento das diferentes demandas dos atores envolvidos no processo decisório, uma vez que amplia o horizonte das discussões a serem efetuadas, servindo como suporte aos tomadores de decisão na aplicação dos instrumentos de gestão, na perspectiva de 
compatibilizar as exigências do desenvolvimento com a manutenção da qualidade ambiental.

A título de indicação para novas pesquisas a serem efetuadas a partir do presente trabalho, alguns caminhos são apontados:

$\checkmark$ Verificar a influência, para os resultados obtidos, da utilização de diferentes abordagens metodológicas e de outros modelos para a projeção das alterações na ocupação do território;

$\checkmark$ Identificar e aplicar outras variáveis (agentes) para a explicação do fenômeno da expansão urbana, inclusive verificando a possibilidade de integração de variáveis sócio-econômicas;

$\checkmark$ Verificar a possibilidade de integração da modelagem com outros instrumentos de gestão e política ambientais. Em particular, com os instrumentos de gestão de recursos hídricos tais como plano de bacia, outorga do direito de uso e cobrança pelo uso da água;

$\checkmark$ Procurar ampliar a área de aplicação da modelagem, por meio da integração de linhas de pesquisa que vêm sendo trabalhadas de modo independente. Por exemplo, avaliando de modo conjunto as demandas relacionadas a aspectos ambientais e as demandas relacionadas à infraestrutura urbana (transportes, saneamento, saúde, educação, etc.). 


\section{REFERÊNCIAS BIBLIOGRÁFICAS}

Ab'SABER, A. (2004). Meio ambiente e urbanização. Palestra proferida durante a Semana do Meio Ambiente. SESC - Ribeirão Preto, junho de 2004.

ACRE (ESTADO) (2000). Governo do Estado do Acre. Programa Estadual de Zoneamento Ecológico-Econômico do Estado do Acre. Zoneamento ecológicoeconômico: indicativos para a gestão territorial do Acre - documento final. Rio Branco: SECTMA. Vol. III.

AGARWAL, C.; GREEN, G. M.; GROVE, J. M.; EVANS, T. P.; SCHWEIK, C. M. (2002). A review and assessment of land-use change models: dynamics of space, time, and human choice. Gen. Tech. Rep. NE-297. Newton Square, PA: U.S. Department of Agriculture, Forest Service, Northeastern Research Station. $61 \mathrm{p}$.

ALMEIDA, C. M. de (2003). Modelagem da dinâmica espacial como uma ferramenta auxiliar ao planejamento: simulação de mudanças de uso da terra em áreas urbanas para as cidades de Bauru e Piracicaba (SP), Brasil. Tese (Doutorado). Pós-Graduação em Sensoriamento Remoto. São José dos Campos, Instituto Nacional de Pesquisas Espaciais - INPE.

ALTON, C. C.; UNDERWOOD, P. B. (2003). Let us make impact assessment more accessible. Environmental Impact Assessment Review, 23: 141-153.

ASPINALL, R. (2004). Modelling land use change with generalized linear models: a multi-model analysis of change between 1860 and 2000 in Gallatin Valley, Montana. Journal of Environmental Management, 72: 91-103.

BOLDRIN, R. S. (2005). Avaliação de cenários de inundações urbanas a partir de medidas não-estruturais de controle: Trecho da bacia do Córrego do Gregório, São Carlos - SP. Dissertação (Mestrado) - Escola de Engenharia de São Carlos, Universidade de São Paulo, São Carlos. 
BOTTARI, T. S. (2005). Gestão Ambiental e Planejamento municipal: articulações e critérios necessários para a produção de cidades sustentáveis. Dissertação (Mestrado) - Escola de Engenharia de São Carlos, Universidade de São Paulo, São Carlos.

BRANDÃO, A. L. P. M. (2001). Clima urbano e enchentes na cidade do Rio de Janeiro. In: GUERRA, A. J. T.; CUNHA, S. B. (orgs.). Impactos ambientais urbanos no Brasil. Rio de Janeiro, Ed. Bertrand Brasil.

BRIASSOULIS, H. (2000). Analysis of Land Use Change: Theoretical and Modeling Approaches. Regional Research Institute, West Virginia University. Disponível em http://www.rri.wvu.edu/WebBook/Briassoulis/contents.htm. Acessado em $16 / 03 / 2004$.

BRITO, E. N. (1996). Avaliação de impacto estratégica: discussão conceitual e metodológica. Avaliação de Impactos, Rio de Janeiro, v.1, n.2, p.69-78.

CANTER, L. W. (1996). Environmental Impact Assessment. 2ª Edição. Nova lorque. 660 p. McGraw-Hill.

CARSJENS, G. J.; Van der KNAAP, W. (2002). Strategic land-use allocaion: dealing with spatial relationships and fragmentation of agriculture. Landscape and Urban Planning, 58: 171-179.

CHARACKLIS, G. W.; WIESNER, M. R. (1997). Particles, metals and water quality in runoff from large urban watershed. Journal of Environmental Engineering, vol. 123, 8: 753-759.

CLARKE, K. C.; GAYDOS, L. (1998). Loose-coupling a cellular automaton model and GIS: long-term urban growth prediction for San Francisco and Washington/Baltimore. International Journal of Geographical Information Science, 12(7), 699-714.

De NIJS, T. C. M.; de NIET, R.; CROMMENTUIJN, L. (2004). Constructing land-use maps of the Netherlands in 2030. Journal of Environmental Management, 72: 35-42.

Di BONA (2000). Environmental Zoning to Help Check Sprawl. The Streamer Newsletter - Spring 2000. Charles River Watershed Association. Boston - MA. Disponível em http:// www.crwa.org. Acessado em 21/12/2001.

DOZENA, A. (2001). São Carlos e seu "desenvolvimento": contradições urbanas de um pólo tecnológico. 160p. Dissertação (Mestrado). Faculdade de Filosofia, Letras e Ciências Humanas, Universidade de São Paulo, São Paulo.

EASTMAN, R. J. (2003). IDRISI Kilimanjaro: guide to GIS and image processing. Clark Labs, Clark University. Worcester, Massachusetts, EUA. 
EMBRAPA - Centro Nacional de Pesquisa de Solos (1999). Sistema brasileiro de classificação de solos. Brasília: EMBRAPA Produção de Informação. Rio de Janeiro. EMBRAPA Solos, 412 p.

FARROW, A.; WINOGRAD, M. (2001). Land use modelling at the regional scale: an input to rural sustainability indicators for Central America. Agriculture, Ecosystems and Environment 85: 249-268.

FILET, M. (1995). Plano de gerenciamento da região lagunar de Iguape e Cananéia. In: Tauk, S. M. (org.). Análise ambiental: uma visão multidisciplinar. São Paulo, UNESP, p.141-142.

FONTES, A. T. (1997). Aspectos do macrozoneamento utilizando SIG enquanto instrumento de gestão ambiental: diagnósticos e cenários regionais no estudo de caso da região de Ribeirão Preto. 67p. Dissertação (Mestrado) - Escola de Engenharia de São Carlos, Universidade de São Paulo, São Carlos.

FREITAS, C. G. L. de; BRAGA, T. de O. ; BITAR, O. Y.; FARAH, F. (2001). Habitação e meio ambiente - abordagem integrada em empreendimentos de interesse social. Publicação IPT 2768. São Paulo, Instituto de Pesquisas Tecnológicas - IPT.

FREY, K. (2000). Políticas públicas: um debate conceitual e reflexões referentes à prática da análise em políticas públicas no Brasil. Planejamento e Políticas Públicas, RJ, n.21(211-259), jun. 2000.

GLASSON, J.; THERÍVEL, R.; CHADWICK, A. (2001). Introduction to environmental impact assessment. London: Spon Press.

GRECCHI, R. C. (1998). Zoneamento geoambiental da região de Piracicaba - SP, com auxílio de geoprocessamento. São Carlos. 132 p. Dissertação (Mestrado). Escola de Engenharia de São Carlos, Universidade de São Paulo.

GUERRA, A. J. T.; CUNHA, S. B. (orgs.) (2001). Impactos ambientais urbanos no Brasil. Rio de Janeiro, Ed. Bertrand Brasil.

HATHOUT, S. (2002). The use of GIS for monitoring and predicting urban growth in East and West St Paul, Winnipeg, Manitoba, Canadá. Journal of Environmental Management, 66: 229-238.

HOWARD, D. M.; HOWARD, P. J. A.; HOWARD, D. C. (1995). A Markov model projection of soil organic carbon stores following land use changes. Journal of Environmental Management 45: 287-302.

JACOBI, P. Meio ambiente urbano e sustentabilidade: alguns elementos para a reflexão. In: CAVALCANTI, C. (org.). Meio ambiente, desenvolvimento 
sustentável e políticas públicas. $3^{a}$. Ed. São Paulo, Cortez. Recife, Fundação Joaquim Nabuco, 2001.

JÄGER, J. (2003). The International Human Dimensions Programme on Global Environmental Change (IHDP). Global Environmental Change 13: 69-73.

LAMBIN, E. F.; TURNER, B.L.; GEIST, H. J.; AGBOLA, S. B. et al. (2001). The causes of land-use and land-cover change: moving beyond the myths. Global Environmental Change 11: 261-269.

LEIS, H. R. (2001). Um modelo político-comunicativo para superar o impasse do atual modelo político-técnico de negociação ambiental no Brasil. In: CAVALCANTI, C. (org.). Meio ambiente, desenvolvimento sustentável e políticas públicas. Ed. Cortez, $3^{a}$. edição. São Paulo.

LEPSCH, I. F. (2002). Formação e conservação do solo. São Paulo: Oficina de Textos, 178p.

LIMA, A. L. B. R.; TEIXEIRA, H. R.; SÁNCHEZ, L. E. (1995). A efetividade da avaliação do impacto ambiental no Estado de São Paulo: uma análise a partir de estudos de caso. São Paulo: Secretaria de Estado de Meio Ambiente Coordenadoria de Planejamento Ambiental.

LIMA, R. S.; SANTOS, V.S.; SILVA, A.N.R. (2005). Using a cellular automata model to support the estimation of future transportation cost. In: INTERNATIONAL CONFERENCE ON COMPUTERS IN URBAN PLANNING AND URBAN MANAGEMENT, 9. London, England, 2005. Proceedings. (CD-ROM). Centre for Advanced Spatial Analysis (CASA), University College London.

LURIA, P.; ASPINALL, P. A. (2003). Evaluating a multi-criteria model for hazard assessment in urban design. The Porto Marghera case study. Environmental Impact Assessment Review, 23: 625-653.

MACHADO, P. A. L. (2002). Direito Ambiental Brasileiro. São Paulo: Editora Malheiros, $10^{\mathrm{a}}$ Edição.

MATO GROSSO (ESTADO) (2003). Zoneamento sócio econômico ecológico do Estado do Mato Grosso. Secretaria de Estado de Planejamento e Coordenação Geral - SEPLAN. Disponível em http://www.seplan.mt.gov.br. Acessado em $15 / 11 / 2004$.

MARANHÃO (ESTADO) (2002). Zoneamento ecológico- econômico do Estado do Maranhão. Gerência de Planejamento e Desenvolvimento Econômico GEPLAN. Disponível em http://www.zeema.gov.br. Acessado em 25/01/2004. 
MARIANO, M. T.; SOUZA, M. P. (1997). A participação da sociedade civil na gestão dos recursos hídricos do Estado de São Paulo. Anais. XII Simpósio da ABRH. Vitória, ES.

MCT - Ministério de Ciência e Tecnologia (2002). Rede Temática de Pesquisa em Modelagem Ambiental da Amazônia - GEOMA. Projeto Científico e Institucional. Versão \#10, Agosto. http://www.geoma.Incc.br/pdfs/versao10.pdf, acessado em 18/03/2005.

MILLIKAN, B. H.; PRETTE, M. E. (2000). AVALIAÇÃO DA METODOLOGIA DO ZONEAMENTO ECOLÓGICO-ECONÔMICO PARA A AMAZÔNIA LEGAL. Manaus - AM, Outubro de 2000. Documento Base para Discussão. Ministério do Meio Ambiente. Secretaria de Coordenação da Amazônia - SCA. Secretaria de Políticas para o Desenvolvimento Sustentável - SDS. Brasília.

MITTERMEIER, A. R.; MEYERS, N.; GIL P. R.; MITTERMEIER, C. G. (2000). Hotspots: Earth's biologically richest and most endangered terrestrial ecoregions. CEMEX/Conservation International. Ed. Agrupación Sierra Madre.

MONTAÑO, M. (2002). Os recursos hídricos e o zoneamento ambiental: o caso do município de São Carlos (SP). 102p. Dissertação (Mestrado) - Escola de Engenharia de São Carlos, Universidade de São Paulo, São Carlos.

MONTAÑO, M.; BERTOLANI, F.; SOUZA, M. P. (2004). Descrição e interpretação das classes de capacidade de uso do solo para o planejamento agro-ambiental e urbano. Trabalho submetido ao Boletim Paranaense de Geociências - UFPR, Curitiba.

MONTAÑO, M.; OLIVEIRA, I. S. D.; RANIERI, V. E. L.; SOUZA, M. P. (2005). A necessidade de incorporação do zoneamento ambiental como instrumento de planejamento e gestão territorial urbana. Congresso Internacional em Planejamento e Gestão Ambiental. Anais. Brasília. Setembro.

MONTAÑO. M.; OLIVEIRA, I. S. D.; RANIERI, V. E. L.; SOUZA, M. P.; FONTES, A. T. (2004). O papel do instrumento zoneamento ambiental no processo de licenciamento de atividades: o caso do novo aterro sanitário do município de Piracicaba (SP). Anais. I Congresso Brasileiro de Ciência e Tecnologia em Resíduos e Desenvolvimento Sustentável - ICTR 2004. Florianópolis. Outubro.

MONTAÑO. M.; OLIVEIRA, I. S. D.; SOUZA, M. P. (2005). A necessidade da informação como parte integrante do processo decisório e a procura pela efetivação dos canais de participação social. Revista OLAM - Ciência e Tecnologia, vol. 5, no. 1. Rio Claro, maio. (CD-ROM)

MOREIRA, I. V. D. (1993). A Experiência brasileira em avaliação de impacto ambiental. In: SANCHEZ, L. E. (Coord.). Avaliação de impacto ambiental: situação atual e perspectivas. São Paulo: EPUSP, pág. 39-45. 
MOTA, S. (1999). Urbanização e meio ambiente. Rio de Janeiro: ABES.

NITSCH, M. (1998). Planejamento sem rumo. Avaliação crítica da metodologia do "Zoneamento Ecológico-Econômico" nos estados da Amazônia brasileira. Parecer elaborado para a Secretaria de Planejamento do Estado de Rondônia Projeto de Cooperação Técnica PNUD/PLANAFLORO. Porto Velho/RO. Obtido em http://www.rondonia.ro.gov.br, acessado em 21/08/2001.

OLIVEIRA, I. S. D. (2004). A contribuição do zoneamento ecológico econômico na avaliação de impacto ambiental: bases e propostas conceituais. Dissertação (Mestrado) - Escola de Engenharia de São Carlos, Universidade de São Paulo, São Carlos.

OLIVEIRA, I. S. D.; SOUZA, M. P. (2005). O zoneamento ambiental e o zoneamento de uso do solo no planejamento e gestão das cidades. Trabalho submetido à Revista Engenharia Sanitária e Ambiental - ABES, Rio de Janeiro.

PARTIDÁRIO, M. R. (1999). Introdução ao ordenamento do território. Universidade Aberta, Lisboa.

PEDROSA, B. M. (2003). Ambiente computacional para modelagem dinâmica espacial. Tese de Doutorado em Computação Aplicada. São José dos Campos, Instituto Nacional de Pesquisas Espaciais - INPE.

PELATTI, I. (2004). Impacto do desenvolvimento urbano da cidade de São Carlos (SP) sobre o rio do Monjolinho e avaliação de sua condição desde as nascentes até a captação do espraiado - de janeiro de 1999 a dezembro de 2003. Dissertação (Mestrado) - Escola de Engenharia de São Carlos, Universidade de São Paulo, São Carlos.

PONTIUS Jr., R. G.; CORNELL, J. D.; HALL, C. A. S. (2001). Modeling the spatial pattern of land-use change with GEOMOD2: application and validation for Costa Rica. Agriculture, Ecosystems and Environment 85: 191-203.

PONTIUS Jr., R. G.; MALANSON, J. (2005). Comparison of the structure and accuracy of two land change models. International Journal of Geographical Information Science. Vol. 19, 2: 243-265.

PONTIUS Jr., R. G.; PACHECO, P. (2004). Calibration and validation of a model of forest disturbance in the Western Ghats, India 1920-1990. GeoJournal 61: 325334.

PONTIUS Jr., R. G.; SCHNEIDER, L. C. (2001). Land-cover change model validation by an ROC method for the Ipswich watershed, Massachusetts, USA. Agriculture, Ecosystems and Environment 85: 239-248. 
PRIESS, J. A.; de KONING, G. H. J.; VELDKAMP, A. (2001). Assessment of interactions between land use change and carbon and nutrient fluxes in Ecuador. Agric. Ecosyst. Environ. 85: 269-279.

RANIERI, V. E. L. (2000). Discussão das potencialidades e restrições do meio como subsídio para o zoneamento ambiental: o caso do município de Descalvado (SP). 87p. Dissertação (Mestrado) - Escola de Engenharia de São Carlos, Universidade de São Paulo, São Carlos.

(2004). Reservas legais: critérios para localização e aspectos de gestão. 149 p. Tese (Doutorado) - Escola de Engenharia de São Carlos, Universidade de São Paulo, São Carlos.

RANIERI, V. E. L.; FONTES, A. T.; SOUZA, M. P. (2002). Determinação da viabilidade ambiental da disposição final de resíduos sólidos domiciliares estudo de caso do município de Descalvado (SP). Anais. III Simpósio Internacional de Qualidade Ambiental. Porto Alegre. ABES-RS. Maio de 2002.

RONDÔNIA (ESTADO) (2001). Zoneamento Sócioeconômico-Ecológico. Governo do Estado de Rondônia. Disponível em www.rondonia.ro.gov.br, acessado em 08/04/2001.

SAE (2000). Coordenação-Geral de Macrozoneamento Geopolítico e Econômico do Território Nacional (COGEC). Secretaria de Assuntos Estratégicos da Presidência da República. Brasília. Obtido em http://www.sae.gov.br/cogec, acessado em 12/12/2000.

SÁNCHEZ, L. E. (1993). Os papéis da avaliação de impacto ambiental. In:

(Coord.). Avaliação de impacto ambiental: situação atual e perspectivas. São Paulo: EPUSP. p.15-33.

SANTOS, R. F. dos (2004). Planejamento ambiental: teoria e prática. Ed. Oficina de Textos. São Paulo.

SÃO CARLOS (2004). Plano Diretor de São Carlos: Projeto de Lei, Proc. 2146.03, PL 215. CD-ROM. Prefeitura Municipal de São Carlos.

SCHNEIDER, L. C.; PONTIUS Jr., R. G. (2001). Modeling land-use change in the Ipswich watershed, Massachusetts, USA. Agriculture, Ecosystems and Environment 85: 83-94.

SELMAN, P. (2000). Environmental Planning. SAGE Pub. $2^{\text {nd }}$ Edition.

SERRES, M. (1990). O contrato natural. Ed. Instituto Piaget. Lisboa. 
SILVA, E. A.; CLARKE, K. C. (2002). Calibration of the SLEUTH urban growth model for Lisbon and Porto, Portugal. Computers, Environment and Urban Systems 26: $525-552$.

SINGHAL, S.; KAPUR, A. (2002). Industrial estate planning and management in India - na integrated approach towards industrial ecology. Journal of Environmental Management, 66: 19-29.

SOLECKI, W. D.; OLIVERI, C. (2004). Downscaling climate change scenarios in an urban land use change model. Journal of Environmental Management 72: 105115.

SOUZA, M. P. (2000). Instrumentos de gestão ambiental: fundamentos e prática. São Carlos: Riani Costa.

SOUZA, M. P., ABDON, M. e OLIVEIRA, I. S. D. (2005). Sustainable development: connections between baseline sustainable zoning and SEA. Conference IAIA. Proceedings. Praga. República Tcheca.

SOUZA, M. P.; FONTES, A. T.; OLIVEIRA, I. S. D.; MONTAÑO, M.; RANIERI, V. E. L. (2003). Zoneamento Ambiental para a localização de aterro sanitário no município de Piracicaba. São Carlos. Relatório Técnico - FIPAI.

STREN, R. et al. (1992). Sustainable cities: urbanization and the environment in international perspective. Boulder: Westview Press.

SULLIVAN, W. C.; ANDERSON, O. M.; LOVELL, S. T. (2004). Agricultural buffers at the rural-urban fringe: an examination of approval by farmers, residents, and academics in the Midwestern United States. Landscape and Urban Planning, 69: 299-313.

SUTHERLAND, R. A.; TOLOSA, C. A. (2000). Multi-element analysis of roaddeposited in an urban drainage basin, Honolulu, Hawaii. Environmental Pollution, 110: 483-495.

THERIVEL, R. et al. (1994). Strategic environment assessment. London: Earth.

TRESS, B.; TRESS, G. (2003). Scenario visualisation for participatory landscape planning - a study from Denmark. Landscape and Urban Planning. 64, 161-178.

TUCCI, C. E. M. (2000). Avaliação e controle dos impactos ambientais decorrentes da urbanização: apresentação do projeto. In: TUCCI, C. E. M.; MARQUES, D. M. (orgs.). Avaliação e controle da drenagem urbana. Porto Alegre. Ed. Universidade, UFRGS. 
TUCCI, C. E. M. (2005). Águas urbanas: interfaces no gerenciamento. In: PHILLIPI Jr, A. (ed.). Saneamento, Saúde e Meio Ambiente. Fundamentos para um desenvolvimento sustentável. Barueri, SP. Ed. Manole.

TURNER, S. J.; O'NEILL, R. V.; CONLEY, W.; CONLEY, M. R.; HUMPHRIES, H. C. (1991). "Pattern and Scale: Statistics for Landscape Ecology". In: Quantitative Methods in Landscape Ecology, M.G. Turner and R.H. Gardner (eds.), págs. 17-50. New York: Springer-Verlag. (mimeo.)

USEPA (2000). Projecting land-use change: a summary of models for assessing the effects of community growth and change on land-use patterns. Relatório EPA/600/R-00/098. Science Applications International Corporation. United States Environmental Protection Agency.

VERBURG, P. H.; SOEPBOER, W.; LIMPIADA, R.; ESPALDON, M. V. O.; SHARIFA M. (2002). Land use change modelling at the regional scale: the CLUE-s model. Environmental Management 30: 391-405.

VERBURG, P. H.; VELDKAMP, A. (2004). Projecting land use transitions at forest fringes in the Philippines at two spatial scales. Landscape Ecology 19: 77-98.

ZANDBERGEN, P. A. (1998). Urban watershed ecological risk assessment using GIS: a case study of the Brunette River watershed in British Columbia, Canada. Journal of Hazardous Materials, 61: 163-173.

ZANNIN, P. H. T.; CALIXTO, A.; DINIZ, F. B.; FERREIRA, J. A. C. (2003). A survey of urban noise annoyance in a large brazilian city: the importance of a subjective analysis in conjunction with an objective analysis. Environmental Impact Assessment Review, 23: 245-255. 